UNIVERSIDADE DE SÃO PAULO

ESCOLA DE ENFERMAGEM

\title{
RECORRÊNCIA DA PARENTALIDADE NA ADOLESCÊNCIA NA PERSPECTIVA DOS SUJEITOS ENVOLVIDOS
}

GERALDO MOTA DE CARVALHO

São Paulo

2006 


\section{RECORRÊNCIA DA PARENTALIDADE NA ADOLESCÊNCIA NA PERSPECTIVA DOS SUJEITOS ENVOLVIDOS}

GERALDO MOTA DE CARVALHO

Tese apresentada à Escola de Enfermagem da Universidade de São Paulo para obtenção do título de Doutor em Enfermagem.

Orientadora:

Prof ${ }^{a}$. Dra. Miriam Aparecida Barbosa Merighi

São Paulo

2006 
Catalogação na publicação (CIP)

Biblioteca "Wanda de Aguiar Horta" da EEUSP

CARVALHO, Geraldo Mota de.

Recorrência da parentalidade na adolescência na perspectiva dos sujeitos envolvidos. / Geraldo Mota de Carvalho. - São Paulo: G. M. de Carvalho, 2006.

$163 \mathrm{p}$.

Tese (Doutorado) - Escola de Enfermagem da Universidade de São Paulo. Orientadora: Prof ${ }^{a} \mathrm{Dr}^{a}$ Miriam Aparecida Barbosa Merighi

1. Mães Adolescentes 2. Pais Adolescentes 3. Fenomenologia. I. Título. 


\section{DEDICATÓRIA}

Ao Rei eterno, único Deus, fonte de todo o conhecimento e sabedoria, pela inspiração e capacitação para realizar mais um projeto desafiador. A Ele, a glória e o louvor sempre! 


\section{AGRADECIMENTOS}

À Prof $^{\mathrm{a}} \mathrm{Dr}^{\mathrm{a}}$ Miriam Aparecida Barbosa Merighi, pela forma como conduziu a orientação deste trabalho e pelo dinamismo, compreensão e paciência nos momentos mais críticos.

Às professoras doutoras, Isabel Cristina Bonadio e Maria Cristina Pinto de Jesus pela participação na banca examinadora e suas valiosas sugestões e observações, que muito enriqueceram o trabalho.

Às professoras doutoras, Isabel Cristina Bonadio, Maria Cristina Pinto de Jesus, Luíza Akiko Komura Hoga, Suzete Maria Fustinoni pela participação no processo de avaliação pró-forma da tese, com suas correções, críticas, sugestões e elogios.

Aos adolescentes, pedras preciosas, brutas, razão de ser desta pesquisa, pela inspiração de que a educação (a lapidação) é a base de todo o desenvolvimento individual.

A meus amigos e familiares que sempre me apoiaram e incentivaram.

Ao Josivan José da Silva, pelo apoio logístico no ramo da informática.

$\mathrm{E}$ a todos que aqui não foram nominados, mas que de uma forma ou de outra contribuíram para a conclusão deste estudo, minha gratidão! 


\section{EPÍGRAFE}

Os adolescentes estão prontos a transformar qualquer desejo em ação. Dos desejos corporais, estão mais dispostos a ceder ao desejo sexual, não exercendo autocontrole. Gostam de honra, mais ainda de vitória. São caridosos mais do que o contrário; confiam, pois não foram ainda uma vez enganados. São veementes e intensos, porque ainda não experimentaram fracassos freqüentes; suas vidas são vividas principalmente de esperança; esperança é o futuro; memória é o passado.

Aristóteles

Filósofo grego, discípulo de Platão e preceptor de Alexandre Magno

(384-322 a. C.) 
Carvalho GM de. Recorrência da parentalidade na adolescência na perspectiva dos sujeitos envolvidos. São Paulo; 2006. 163 p. Tese (Doutorado) - Escola de Enfermagem. Universidade de São Paulo.

\section{Resumo}

Este estudo objetivou conhecer e compreender como foi constituída a percepção que os adolescentes têm da parentalidade recorrente na adolescência. Para compreender o significado desta experiência e a relação com seus projetos de vida utilizei-me do método qualitativo com enfoque na Fenomenologia Social. Foram realizadas 15 entrevistas com cinco pais e dez mães que haviam experienciado a parentalidade recorrente com as seguintes questões norteadoras: Como foi para você ser mãe/pai pela primeira vez? Como aconteceu o nascimento do outro filho? Como é ser mãe/pai mais de uma vez, ainda adolescente? O que você espera do futuro, sendo mãe/pai tão jovem? Dos depoimentos, emergiram cinco categorias concretas do vivido: Contextualizando a percepção sobre ser pai/mãe adolescente, que implicou na construção de duas subcategorias: sendo pai/mãe pela primeira vez e pai/mãe mais de uma vez; Vivenciando perdas; Vivenciando ganhos, com duas subcategorias: sentindo-se amadurecidos /responsáveis e expressando satisfação com a parentalidade; Buscando segurança para o futuro e Experienciando situação ambivalente. O estudo permitiu compreender que a parentalidade adolescente recorrente é um fenômeno complexo, multifacetado, de inesgotável possibilidades perceptivas, cujas diversas vivências são dependentes do contexto social que define os desejos, os projetos, as possibilidades e as significações nas distintas classes sociais. Com este entendimento, em uma relação face a face, de intersubjetividade, respeitando a singularidade dos adolescentes, o enfermeiro tem uma situação de destaque no assistir/cuidar desta clientela, centrado na dimensão humana /existencial.

Palavras-chave: Pais adolescentes; Mães adolescentes; Fenomenologia. 
Carvalho GM de. Repeated parenthood in adolescence in the perspective of the subjects involved. São Paulo; 2006. 163p. Thesis (Doctorate) - São Paulo University Nursing School.

\begin{abstract}
The goal of this study was to know and understand how the perception adolescents have of the recurring parenthood during adolescence was constituted. To comprehend the meaning of this experience and the relation with their life projects the qualitative method was used, focusing the social phenomenology. Fifteen interviews were carried out with five fathers and ten mothers who had experienced the recurring parenthood as an unveiling strategy of the phenomenon, using the following directive questions: How did you feel becoming a first-time mother/father? How did the birth of another child take place? How does it feel to be a mother/father more than once, still being an adolescent? What do you expect of the future, being such a young mother/father? Five concrete categories of the experienced surfaced from the subjects' statements: Contextualizing the perception about being an adolescent mother/father - with two subcategories: being a first-time parent and a parent more than once; Experiencing losses; Experiencing gains - with two subcategories: feeling more mature/responsible and expressing satisfaction with parenthood; Seeking safety for the future; and Experiencing an ambivalent situation. The study allowed the understanding that recurring adolescent parenthood is a complex, multi-faceted phenomenon, with endless perceptive possibilities, of which the diverse experiences depend on the social context that defines wishes, projects, possibilities and meanings through the distinct social classes. Based on this understanding, during a face-to-face relationship of intersubjectivity, respecting the adolescents' singularity, the nurse plays a very important role as regards assisting/taking care of this clientele, centered on the human/assisting dimension.
\end{abstract}

Keywords: Adolescent fathers; Adolescent mothers; Phenomenology. 


\section{SUMÁRIO}

01 INQUIETAÇÕES E OBJETIVO DO ESTUDO

02 A GRAVIDEZ E PARENTALIDADE NA ADOLESCÊNCIA E SUA RECORRÊNCIA

03 JUSTIFICATIVA DO REFERENCIAL METODOLÓGICO

3.1 Opção pelo método qualitativo

3.2 Opção pela abordagem fenomenológica

3.3 Opção pelo referencial teórico-filosófico

04 O REFERENCIAL FILOSÓFICO DE ALFRED SCHÜTZ E SEUS CONSTRUCTOS

4.1 O mundo da vida

4.2 Atitude natural

4.3 Intersubjetividade

4.4 Situação biográfica

4.5 Acervo de conhecimentos disponíveis

4.6 Ação

4.7 Teoria da motivação

4.8 Relação face a face

4.9 Tipificação

05 PROCEDIMENTO METODOLÓGICO

5.1 Sujeitos da pesquisa e região de inquérito

5.2 Descrição do processo de coleta de dados

5.3 Questões éticas

5.4 Momento da análise compreensiva

06 ESQUEMAS REPRESENTATIVOS DO ESTUDO

6.1 Esquema da pesquisa

6.2 Esquema da metodologia

6.3 Esquema da Fenomenologia de Alfred Schütz

07 CATEGORIAS CONCRETAS EMERGIDAS DO VIVIDO

08 CONSTRUÇÃO DO TIPO VIVIDO

09 ANÁLISE COMPREENSIVA DO TIPO VIVIDO: PAIS E MÃES ADOLESCENTES RECORRENTES

9.1 Esquema representativo do típico da vivência dos adolescentes pais e mães recorrentes

10 CONSIDERAÇÕES GERAIS

REFERÊNCIAS

BIBLIOGRAFIA COMPLEMENTAR

ANEXOS 


\section{INQUIETAÇÕES E OBJETIVO DO ESTUDO}

Uma jornada de duzentos quilômetros começa com um simples passo. Provérbio chinês

O melhor investimento que uma sociedade pode realizar para seu futuro é ajudar os adolescentes a desenvolverem-se de forma saudável e plena de realizações.

O envolvimento profissional com os adolescentes, tanto na assistência como no ensino sempre me seduziu. Ao mesmo tempo, a gravidez precoce que me causa estranheza, também, é familiar pois faz parte de meu mundo-vida. Vários casos vivenciados, envolvendo a concepção precoce, inclusive, em meio de familiares mobilizaram minha atenção no que diz respeito à parentalidade ${ }^{1}$ nesta etapa do ciclo vital.

Para compreender a temática em questão, questiono se não existe uma lacuna entre o fazer da equipe de saúde e as reais necessidades dos adolescentes.

Por ser também Especialista em Planejamento Familiar, sempre estive atento às necessidades especiais dos adolescentes no controle de sua função reprodutiva. Elaborei um guia de orientação anticoncepcional, visando a alcançar esta clientela (Carvalho, 1987).

Tenho ministrado palestras sobre métodos anticoncepcionais em locais diversos. Assim, preocupado com esta fase da vida tão importante ao desenvolvimento biopsicossocial, momento de muitas descobertas, aventuras e desafios, elaborei e colaborei com vários textos científicos (Carvalho, 1996; Carvalho et al., 1997; Carvalho e Garofalo, 1998; Carvalho

\footnotetext{
${ }^{1}$ Parentalidade: Os dicionários não registram este substantivo que poderia ser definido como qualidade, condição ou situação de pai e mãe. Optou-se por utilizá-lo a exemplo de alguns autores referenciados neste estudo (Levandoswki e Piccinini, 2004; Fonseca, 2001; Medrado e Lyra, 1999; Nóbrega, 1997 e outros). Na língua inglesa, existe o vocábulo equivalente que é parenthood.
} 
e Silva, 1999; Carvalho e Barros, 2000; Carvalho e Antognetti, 2002; Carvalho et al., 2003; Carvalho e Acocella, 2003; Carvalho e Silva, 2003; Carvalho, 2004; Carvalho e Franchi, 2004; Carvalho et al., 2005; Carvalho e Ramos, 2005; Carvalho e Merighi, 2006).

No entanto, os vinte anos de experiência profissional, como enfermeiro assistencial e docente, convivendo com a gravidez precoce, não foram suficientes para compreender com clareza a realidade desse evento e as reais necessidades de cuidado aos adolescentes.

Em 1997, preocupado com esta temática ingressei no programa de Pós-graduação da Universidade Federal de São Paulo e desenvolvi a dissertação intitulada "Fatores psicossociais relacionados à gravidez na adolescência: subsídios para a assistência e prevenção" (Carvalho, 1998).

Nesta pesquisa, encontrei que a gravidez na adolescência muitas vezes constituiu-se em um projeto de vida, provavelmente, para compensar um vazio existencial, sem imaginar as responsabilidades implicadas.

\footnotetext{
“...Meu filho vai me dar o amor...., "...vou ter alguém para cuidar...", “...tudo vai melhorar agora que meu filho nasceu...", "...não sei...talvez o pai do neném queira ficar junto comigo...", "... ah!, ...eu achei que se eu engravidasse ele ficaria comigo...", “...queria ter minha liberdade...", "... engravidei pra sair de casa...”.

Estas verbalizações diziam respeito a uma nova vida e à esperança de que o filho faria tudo mudar para melhor, fatos que me fizeram, na época, pensar na presença de dois tipos de sentimentos interligados: baixa autoestima e dependência. As adolescentes depositavam no filho a possibilidade de serem amadas por alguém. Percebi que a possibilidade de ter amor e
} realização dependia do outro.

No estudo mencionado, foi possível verificar também que a gravidez na adolescência fazia parte do mundo-vida dessas jovens, pois 52\% delas eram filhas de mães que também foram mães na adolescência e, muitas vezes, tinham irmãs que tiveram filhos quando adolescentes.

Constatei, que a repetição da gravidez nesse período não é incomum, 
o que me causou muita estranheza.

Assim sendo, quando me despertou o interesse por cursar 0 doutorado, o tema escolhido para pesquisa foi a recorrência da maternidade/paternidade na adolescência. Desta vez, o interesse incidiu sobre a compreensão da experiência dos sujeitos que vivenciam o fenômeno.

Pela literatura científica, verifiquei que existem muitas pesquisas sobre a concepção precoce (Garcia, 1984; Garcia, 1996; Madeira, 1998; Souza, 1999; Mandu, 2001; Bocardi, 2003; Gomes, 2004). Estudos estes que não foram suficientes para compreender toda sua vasta extensão.

Muitos autores teorizam sobre o tema e ressaltam a informação e educação sexual nas escolas, como estratégia para sua redução. No entanto, questiono será que apenas informações a respeito da anatomia e fisiologia dos aparelhos reprodutores humanos e métodos anticoncepcionais poderiam modificar comportamentos e despertar os adolescentes para sua vulnerabilidade?

A maternidade precoce é, sem dúvida, um grave problema de saúde pública. No entanto, o foco dos estudiosos desta temática volta-se, na maioria das vezes, a problemas biopsicossociais (Abrahamse; Morrison; Waite, 1988; Marsiglio, 1993; Levinson, 1995; Barbosa et al., 1997; Dias, 1997; Bull e Hogue, 1998; Carvalho, 1998; Carvalho e Silva, 1999; Souza, 1999; Cano e Ferriani, 2000; Bogaski et al., 2000; Dotta et al., 2000; Levandowski, 2001; Ramos, 2001; Sadigurski, 2001; Carvalho e Antognetti, 2002; Gomes, Fonseca, Veiga, 2002; Carvalho e Acocella, 2003; Carvalho e Franchi, 2004; Bello e Silva, 2004; Gomes, 2004).

Para controlar tal fenômeno, Madeira e Tsunechiro (2003) comentam a respeito de medidas intervencionistas e preventivas ou quem sabe uma "vacina" precisa ser posta em prática para combater essa "doença", essa "praga", conforme referem os estudiosos do assunto. 
Conforme estas autoras, a literatura médica clássica mostra que a preocupação volta-se às conseqüências de uma maternidade precoce, tanto às mães como à criança, família e sociedade.

A maioria dos estudos relacionados ao tema apóia-se em uma abordagem positivista, baseada em fatos objetivos e causalidades, não se utilizando da vivência dos sujeitos. Nenhum deles abordou a questão subjetividade na paternidade/maternidade adolescente recorrente.

Questiono, ainda, se a gravidez na adolescência não será mais um problema social do que biopsicoemocional? Neste sentido, destaco o comentário de Dimenstein e Lambert (1998), que "é impossivel construir uma sociedade menos estúpida com milhão de adolescentes grávidas todos os anos".

Desse modo, a presente investigação buscou explorar a experiência da parentalidade recorrente na adolescência sob a perspectiva do sujeito que a vivencia, com a intenção de preencher a vacuidade existente nos estudos, sobretudo, no que diz respeito à recorrência da parentalidade e inclusão dos pais.

Optei por incluir os adolescentes pais na pesquisa, concordando com Marsiglio (1993); Bull e Hogue (1998); Fonseca (2001); Levandowski, (2001); Medrado e Lyra (2006) ,quando ressaltam que, ao se tratar de gravidez precoce, geralmente, estes são excluídos. Fala-se das conseqüências da concepção à mãe, esquecendo-se do pai adolescente. Qual impacto teria a paternidade adolescente nas diversas esferas da vida?

Cushnir $^{2}$ refere-se aos jovens pais e salienta que muitos companheiros das adolescentes negam a paternidade, vivem momentos de depressão e, dificilmente, terão uma boa relação com a criança. O autor

\footnotetext{
${ }^{2}$ Cushnir L. Entrevista sobre a participação masculina na gravidez adolescente, concedida
} a um canal de televisão em 1997. 
citado comenta que alguns desses jovens podem sentir-se usados pelas mulheres. Outros podem aceitar a paternidade, mas terão dificuldade para estabelecer uma relação amorosa com a criança. Isto porque ela surge, geralmente, quando eles não têm uma formação profissional nem valores éticos formados. O autor cita que as adolescentes mães, talvez, sofram o maior ônus da gravidez precoce, mas, certamente esta também pese nos ombros do pai adolescente.

Por outro lado, se a adolescente interromper a gestação, muitos desses jovens poderão ficar ressentidos porque gostariam de ter a criança. Esta experiência poderá influenciar seus relacionamentos amorosos posteriores.

Neste cenário, na presente pesquisa, meu caminho conduziu-me a buscar a compreensão do fenômeno, ser pai/mãe adolescente recorrente, com base na vivência do outro em uma dimensão existencial compreensiva. A maneira de vivenciar o fenômeno pode apresentar-se de modo diferente na visão de quem o experiência e na dos estudiosos da temática.

A fim de pensar novas formas que contribuam para a atuação dos enfermeiros frente a assistência aos adolescentes e considerando o modo como estes vivenciam o fenômeno, optei por realizar este estudo, buscando responder às minhas inquietações.

Os sujeitos que vivenciam o fenômeno têm expectativas e motivações que se fundamentam no conhecimento e experiências vividas intersubjetivamente e que podem ser manifestadas de forma subjetiva.

As minhas vivências profissionais, meu conhecimento prévio sobre o tema e a revisão da literatura permitiram-me fazer os seguintes questionamentos:

- Como os adolescentes que são pais ou mães experienciam a parentalidade?

- Como é passar por esta experiência quando ainda se é jovem? 
- Como é experienciar a parentalidade mais de uma vez quando ainda se é jovem?

A pesquisa foi desenvolvida no intuito de desvelar a recorrência da parentalidade na adolescência. Seu ponto de partida teve como marco a ótica dos sujeitos que vivenciam o fenômeno, seja como mãe ou pai adolescente. Para tanto, o seguinte objetivo foi estabelecido:

- Conhecer e compreender como é constituída a percepção que os adolescentes mães e pais têm da parentalidade, recorrente na adolescência.

Com este objetivo, caminhei à procura do significado da parentalidade recorrente na adolescência. Acredito que esse conhecimento contribuirá significativamente no sentido de subsidiar o cuidado de Enfermagem dirigido a esta clientela e incrementar o ensino e pesquisa na área de Enfermagem na saúde da mulher.

Não tive a pretensão de conduzir este estudo, seguindo uma revisão da literatura a respeito do objeto investigado, pois como afirma Merighi (1993), não é necessário investigar teorias, modelos e pensamentos sobre o tema para compreender se tais modelos são verdadeiros ou falsos. Minha intenção foi buscar o fenômeno que só se mostra ao ser interrogado.

Para contextualizar o leitor em relação à temática de estudo, julguei necessário apreender da literatura aspectos concernentes à gravidez e parentalidade recorrente na adolescência. 


\section{A GRAVIDEZ E PARENTALIDADE ADOLESCENTE E SUA RECORRÊNCIA}

Apesar do grande progresso sociocientífico-cultural das últimas décadas, observa-se que a sexualidade dos adolescentes continua sendo um tabu e motivo de vergonha para discussão.

Vergonha, insegurança, medo, estereótipos e preconceitos ampliam a vulnerabilidade dos adolescentes a problemas relativos à sexualidade $\mathrm{e}$ reprodução, sobretudo, quando essas vivências esbarram na falta de apoio familiar e social (Mandu, 2001).

Estas transformações sociocientífico-culturais acrescidas da diminuição da idade da menarca (OMS, 1996) acabaram estimulando os adolescentes a iniciar a atividade sexual precoce, sem, no entanto, preparálos para seu exercício (WHO, 1989; IEPD, 1996; Dias, 1997; Monteiro, 1998; Ureña, 1998; Carvalho e Merighi, 2004).

Para estes autores, a iniciação sexual precoce e, conseqüentemente, o aumento da atividade sexual do adolescente não são acompanhados do crescimento proporcional de precauções contraceptivas.

A vida sexual dos jovens está começando mais cedo e a precocidade é maior entre os homens, cujas médias variam de 14,5 a 16,4 anos. Para as mulheres, são de 15,2 a 20,6 anos (Berquó, 2000).

Em alguns casos, os adolescentes desconhecem ou usam de maneira incorreta os métodos anticoncepcionais. Muitas vezes, praticam a anticoncepção de maneira descontinuada pelo caráter esporádico de suas relações sexuais e pela desinformação a respeito da anatomia e fisiologia dos aparelhos reprodutores. Mesmo conhecendo os métodos anticoncepcionais, o psiquismo dos adolescentes pode produzir bloqueios e esquecimentos que levam a não os utilizar, visto que fora do casamento, no 
geral, a relação sexual não é socialmente autorizada (Barbosa et al., 1997; Carvalho, 2004).

No estudo sobre a prática anticoncepcional na adolescência, Sadigursky (2002) observou que $46 \%$ das adolescentes abandonaram o uso dos contraceptivos. Para a autora, ainda existem razões não muito claras para a prática anticoncepcional de maneira descontinuada nessa faixa etária.

Para Charpie-dubrit (1991), os motivos que levam os adolescentes a não usar os métodos anticoncepcionais são: dificuldade para obtê-los, por achar que a gravidez não vai acontecer, diminuição do prazer sexual e que são antinaturais. $O$ autor citado apontou, também, que as conseqüências da gravidez na adolescência referem-se a não planejada ou ser indesejada, indesejada e repetida, de risco, casamento forçado e alto índice de separação, evasão escolar e problemas na educação dos filhos por falta de preparo para a maternidade e paternidade.

Estudiosos como Abrahamse, Morrison, Waite (1988), há anos já se preocupavam com a questão da maternidade na adolescência e relacionaram algumas influências biológicas, sociais e ambientais que poderiam influenciar a iniciação das relações sexuais, entre elas, estão:

As influências biológicas: a maturidade sexual precoce com freqüência associada à atividade sexual precoce; o aumento dos níveis hormonais influi diretamente e aumenta a motivação e o comportamento sexual entre adolescentes do sexo masculino.

As influências sociais: diferentes grupos sociais têm padrões distintos de comportamento heterossexual pré-coital na adolescência precoce. O padrão de atividade sexual começa cedo e progride mais rápido entre as negras do que entre as brancas. Entre as brancas, há um longo período de namoro sem coito, antes do primeiro ato sexual. Fortes crenças religiosas são capazes de inibir a relação sexual entre adolescentes; alta 
expectativa educacional e aspirações de carreira estão associadas ao adiamento da atividade sexual. A estrutura das famílias com início de atividade sexual precoce entre adolescentes vindos de famílias desfeitas; influência de adolescente que tem uma irmã que foi mãe adolescente estão mais sujeitas a ser sexualmente ativas.

As influências ambientais: a vizinhança onde a adolescente vive; jovens mulheres vivendo em pobreza enfrentam risco aumentado para a atividade sexual precoce; colegas que aceitam a maternidade, se solteiras podem influenciar uns aos outros na escola e na comunidade, em geral, com o aumento do risco para a maternidade, sem a assunção da criança pelo pai.

A Organização Panamericana de Saúde define a maternidade na adolescência a que ocorre durante os primeiros anos reprodutivos da mulher (considerando a menarca como o ponto zero da idade reprodutiva), e/ou quando a adolescente mantém uma total dependência social e econômica da família. Ela tem sido chamada de Síndrome do fracasso ou porta de entrada ao ciclo da pobreza e feminilização da pobreza (OPS, 1992).

Nas últimas décadas no mundo, a reincidência da gravidez (e parentalidade) na adolescência tem aumentado, porém esta fica mais evidente nos países emergentes, tendo em vista a pouca escolaridade, a falta de informação, a desagregação familiar, a instabilidade econômica, especialmente, nas adolescentes de nível socioeconômico mais baixo (Carvalho e Merighi, 2004).

Nos últimos anos no Brasil, observamos que a taxa de fecundidade da mulher adulta abaixou; no entanto, parece estar aumentando na população adolescente (Brasil, 1997³).

Entre 1993 e 1996, o número de partos, na faixa de dez a 14 anos

3 Brasil. Ministério da Saúde. Secretaria de Projetos Especiais de Saúde. Coordenação Materno-Infantil. Serviço de Assistência à Saúde do Adolescente. Prevenção intersetorial da gravidez na adolescência [documento preliminar]. Brasília (DF); 1997. 
passou de 26.505 para 31.911, dos 15 aos 19 anos, passou de 611.608 para 675.839.

As estimativas indicam que o crescimento continuou nos anos seguintes. Se partirmos da premissa de que são necessários dois participantes para que haja a gravidez e que a grande maioria dos pais dos filhos das adolescentes é também adolescente, isto significará que quase dois milhões de adolescentes, por ano, estão envolvidos nessa situação (Brasil,1997).

Do total de partos realizados nos hospitais conveniados com 0 Sistema Único de Saúde (SUS), em 1996, cerca de 26\% foram de adolescentes. Nas demais faixas etárias, a tendência é de contínua diminuição, o que poderia explicar a queda no crescimento populacional (Brasil, 1997). Estes números são subestimados, registram apenas os dados do SUS, sem considerar os partos domiciliares em comunidades faveladas, em bairros periféricos das grandes cidades, nas cidades do interior e, sobretudo nas regiões Norte e Nordeste do País, onde ainda atuam muitas parteiras leigas.

Em 1970, o número médio de filhos de uma adolescente de 15 anos, em cada 100 mulheres em idade reprodutiva, era de 1,2 passando para 2,1 em 1980 (Takiuti, 1993).

A literatura obstétrica clássica (WHO, 1996; Neme, 2000; Rezende e Montenegro, 2003 e outros) afirma que a maternidade precoce pode apresentar alguns riscos biológicos e psicossociais ao binômio mãe-filho, representados por maiores complicações obstétricas, maiores taxas de morbidade e mortalidade neonatais e infantis, maior porcentagem de prematuridade e desnutrição intra-uterina e pós-natal e maior deterioração do nível socioeconômico. Entretanto, o risco social, diferente do biológico, é sabidamente maior e mais difícil de prevenir. As mães adolescentes costumam apresentar menor auto-estima e poucas metas para o futuro, 0 que também repercute no bem-estar de seu filho, sobretudo, quando existir a 
ilegitimidade ou a ausência do companheiro (Carvalho, 1998).

Burrows et al. (1974b; 1994a) encontraram fatores estatisticamente à gravidez precoce, entre eles: baixa escolaridade paterna, gravidez precoce materna, instabilidade familiar, geralmente, com a ausência paterna, grande permissividade paterna associada a maiores castigos, escassa prática familiar de um culto religioso, baixo rendimento escolar, deserção escolar precoce e menor coeficiente intelectual da adolescente.

Os últimos autores citados perceberam que a gravidez na adolescência mostra-se altamente associada a uma menor auto-estima, a um menor funcionamento intrafamiliar e menor qualidade das atividades de tempo livre. Assim, a falta de apoio e de afeto familiar em uma adolescente com baixa auto-estima, mal-rendimento e grande permissividade familiar, além de grande disponibilidade de tempo livre, poderiam induzi-la a buscar na maternidade precoce o meio para conseguir afeto incondicional, talvez, uma família própria, reafirmar seu papel de mulher ou descobrir-se ser indispensável para alguém.

Carvalho (1998) semelhante a esses autores encontrou os seguintes fatores psicossociais relacionados à gravidez na adolescência: fracasso escolar; ausência de ocupação e de prática religiosa; o baixo nível socioeconômico; pensamento de onipotência; influência intergeracional e a permissividade familiar.

Ao constatarem uma gravidez, são freqüentes os relatos de adolescentes grávidas que buscam ou, pelo menos, pensam na prática do abortamento, freqüentemente, pondo em risco a saúde.

Muitas vezes, estas adolescentes interrompem seus estudos e/ou deixam seus empregos. Assim, ao se tornarem mães, perdem a liberdade, adiam projetos de estudos, limitam suas expectativas de ingresso no mercado de trabalho e até de ter um relacionamento amoroso satisfatório. 
Muitas na busca precoce de uma vida sexual iniciam uma vida familiar (Souza, 1999; Vieira et al., 2000).

Segundo a Pesquisa Nacional de Demografia em Saúde, em 1996, uma em cada dez adolescente de 15 a 19 anos já tinha um filho e, aos 19 anos, uma em cada três, já era mãe (Brasil, 1997). Como conseqüência natural do crescimento da ocorrência da gravidez acontece, também, o aumento no número de abortamentos ou maternidade recorrente.

Em 1996, nos hospitais do SUS, foram internadas 53.215 adolescentes com história de abortamentos incompletos, sendo algumas submetidas à curetagem ginecológica (Brasil, 1997).

Em 1985, no Estado de São Paulo foram registradas quase 3.000 crianças, cujas mães eram menores de idade. Este número é menor que o real de nascimentos, pois muitas pessoas acreditam que, por ser menor de idade, as mães não podem registrar seu filho, somado ao constrangimento de se declarar mãe prematuramente (Bocardi, 2003). Esta autora registra dados estatísticos mostrando que $40 \%$ das adolescentes voltam a engravidar, após 36 meses da primeira gestação.

Carvalho (1998) verificou que 62\% das adolescentes não usavam métodos anticoncepcionais e a recorrência da segunda gestação, nesta faixa etária, foi de $14 \%$ e da terceira gestação 5\%, em uma amostra de 100 indivíduos entre 12 e 19 anos.

As razões das mães adolescentes para não usar de maneira eficaz contraceptivos, antes da primeira gravidez, podem ajudar a predizer a ocorrência de concepções subseqüentes ainda nessa faixa etária. Neste sentido, Stevens-Simon et al. (2001) constataram que as adolescentes que atribuíram o fracasso ao uso ineficaz de contraceptivos aos efeitos colaterais dos métodos ou à falta de motivação à prevenção da gravidez, sentem-se menos propensas a utilizar anticoncepcionais após o parto e, assim, a conceber de novo, ao contrário, daquelas que assumiram sua ignorância a 
respeito dos métodos anticoncepcionais.

Com base neste fato, estes autores sugerem que as futuras pesquisas deveriam focar a atenção no desenvolvimento de intervenções mais efetivas para prevenir concepções repetidas entre adolescentes com capacidade de prevenir suas gravidezes, mas, usaram "desculpas" para não o fazer, pois estas são mais vulneráveis à repetição.

A literatura obstétrica mostra que existe uma época favorável à reprodução, que o organismo materno necessita de razoável espaço de tempo para refazer-se após uma gestação. O excessivo número de gravidezes, intervalo intergestacional menor que 18 meses pode repercutir desfavoravelmente na saúde materna e fetal, sobretudo quando a maternidade começa muito precoce (WHO, 1996; Dotta et al., 2000; Neme, 2000; Rezende e Montenegro, 2003).

No Estado de São Paulo, em 1998, foram feitos 45 mil partos de adolescentes que estavam na terceira gravidez (Cotes, Aranha, Barbi, 2004).

Para Almeida et al. (2003), a maternidade na adolescência é um grande desafio que precisa ser enfrentado. Estudo realizado com 140 adolescentes no interior paulista, constatou que $24 \%$ destas já estavam na segunda, terceira, quarta ou até quinta gestação e 10\% já haviam praticado aborto, pelo menos, uma vez.

No estudo realizado em uma maternidade filantrópica da cidade de São Paulo, Gomes (2004) constatou uma reincidência de gestações na adolescência de 30,4\%. Belo e Silva (2004) verificaram uma repetição da concepção na adolescência (duas ou mais) em 22, 2\%.

O estudo norte-americano sobre fatores determinantes da repetição da gravidez entre adolescentes verificou que a repetição pode ocorrer dentro de um contexto de relações pobres entre pais e crianças; apoio conflitivo nos papéis que se espera que mães adolescentes assumam; pressões sociais 
limitadas para uma paternidade efetiva e acesso limitado a serviços sociais a todos os membros da família (Bull e Hogue, 1998).

Conforme afirma a Organização Panamericana de Saúde, quando uma jovem engravida, a notícia é recebida com evidente desgosto pelo companheiro, sua família e pessoas de seu meio social (trabalho e escola). Não existem informações de que a maternidade na adolescência seja bem recebida inicialmente em nenhum grupo da maioria das sociedades atuais (OPS, 1992).

Quanto ao parceiro da mãe adolescente, este, não poucas vezes, também, é outro adolescente ou um adulto muito jovem, com pouca maturidade, com perfil semelhante ao da mãe no tocante à escolaridade, situação profissional e classe social. Nesta faixa etária, muitas vezes, as gestações não são planejadas, forçando o início da participação do adolescente no mercado de trabalho, assumindo um subemprego, um casamento mais cedo do que o esperado e, conseqüentemente, uma atividade sexual sem uso de anticoncepcional adequado, levando a uma prole numerosa (Carvalho e Merighi, 2004).

$\mathrm{Na}$ adolescência, a maternidade tem conseqüências psicossociais à mãe, pai, criança, familiares e sociedade. No entanto, estas são privilegiadas à mãe, esquecendo-se o pai. Para Levandowski (2001), existe uma carência de estudos sobre o tema da paternidade na adolescência. Em sua revisão de literatura a respeito do assunto, no período de 1990 a 1999, encontrou apenas 68 artigos científicos no âmbito internacional; no âmbito nacional seus achados foram em proporções semelhantes.

Marsiglio (1993) salienta que a paternidade nesta faixa etária pode ser uma afirmação da masculinidade e virilidade. Assim, os jovens cientes de que foram responsáveis por uma gravidez prévia, são menos prováveis de utilizar anticoncepcionais eficientemente do que aqueles que nunca engravidaram alguém. Os primeiros costumam relatar prazer na paternidade e um "realce" em sua masculinidade. 
Nos últimos anos, a preocupação com a saúde do adolescente ganhou proeminência mundial. Assuntos relacionados à saúde reprodutiva são de importância vital aos jovens, conforme estão se preparando para desempenhar o papel de adultos e representar o futuro de uma nação.

Para Sadigursky (2002), os programas educacionais executados até o momento demonstram que a informação tem chegado até os adolescentes de maneira satisfatória, faltando, portanto, o desenvolvimento de esquemas comportamentais. Muitas adolescentes, independente da classe social, mesmo conhecendo métodos anticoncepcionais, muitas vezes, não os usam, provocando o crescimento da geração das avós que também são pais de seus netos, tomando para si a responsabilidade de criá-los.

Ao estudar a relação entre conhecimento reprodutivo-contraceptivo e comportamento contraceptivo para entender o uso ineficaz de anticoncepcionais, Levinson (1995) concluiu, citando cinco outros autores, que o fornecimento de informações sobre reprodução/contracepção aos adolescentes não assegura necessariamente que eles usem melhor os anticoncepcionais ou alterem seus comportamentos sexuais.

Assim sendo, embora tenha vivência profissional, além da revisão da literatura, percebo que existe algo oculto na vivência desses adolescentes que já vivenciaram a maternidade, a paternidade e o fenômeno da parentalidade recorrente.

Desse modo, pretendo com os resultados obtidos nesta pesquisa contribuir para a assistência de Enfermagem aos adolescentes e elaboração de programas de saúde e outras investigações na área.

No próximo item, discorrerei sobre a justificativa da escolha metodológica da pesquisa. 


\section{JUSTIFICATIVA DO REFERENCIAL METODOLÓGICO}

\section{1 Opção pelo método qualitativo}

A assistência aos adolescentes requer 0 conhecimento das peculiaridades próprias dessa faixa etária, pelo seu modo peculiar de experienciar o mundo. Portanto, a busca da compreensão desse fenômeno agora se faz necessária.

Acredito que o conhecimento das peculiaridades do vivido pelos adolescentes represente também um passo importante na formação profissional do enfermeiro. Este profissional, sabidamente, tem formação adequada para a assistência aos adolescentes, sobretudo, no que diz respeito às atividades educativas.

Percebo a preocupação dos profissionais em relação à promoção da saúde dos adolescentes. Constato isto por meio da grande quantidade de dados bibliográficos nacionais e internacionais e eventos científicos sobre a temática, encontros profissionais e pela mídia.

As publicações sobre o tema em questão, como já salientado, são basicamente quantitativas, relacionadas aos aspectos biopsicossociais. Quase não existe literatura sob o ponto de vista de quem vivencia a parentalidade recorrente na adolescência.

Gomes et al. (2002) em estudo bibliográfico do tipo exploratório descritivo-retrospectivo, analisaram publicações em revistas de Medicina Pediátrica, entre os anos de 1990 a 1999. Não encontraram trabalho algum com abordagem qualitativa sobre a gravidez na adolescência ou sua recorrência. Entre as publicações de outros profissionais de saúde, a situação não é muito diferente. Segundo a OPS/OMOS/FPNU (1996), este fato caminha, de forma oposta, à tendência atual de estudar os fenômenos relacionados aos contextos pessoais e sociais no campo da saúde por meio dessa abordagem. 
O conhecimento teórico-prático da temática abordada conduziu-me ao entendimento sobre a realidade da vida cotidiana que requer um encaminhamento metodológico que desvele motivos, intenções, valores, sentimentos, projetos, percepções e as expectativas dos adolescentes em relação à concepção. Por acreditar no pressuposto de que a realidade social não se esgota nos dados quantitativos, optei pela realização de um estudo qualitativo, como estratégia para compreensão dos significados e vivências da maternidade e paternidade recorrentes nesta faixa etária. As questões, advindas das experiências vividas pelos sujeitos podem ser compreendidas à luz da fenomenologia sociológica.

Para conhecer e compreender o fenômeno da recorrência da maternidade/paternidade em adolescentes, é necessário ouvir dos jovens os motivos existenciais que levaram à repetição da parentalidade, pois estes sujeitos experienciam essa situação de forma intencional e atribuem a ela significados, de acordo com sua visão de mundo, seus costumes, saberes e valores, vividos intersubjetivamente com o outro.

\section{2 Opção pela abordagem fenomenológica}

A necessidade de compreender o fenômeno da recorrência da parentalidade na adolescência levou-me a indagar e a investigá-lo por meio de uma abordagem qualitativa fenomenológica.

O fenômeno surge e manifesta-se para a consciência como resultado de uma interrogação. Isto significa que só existirá um fenômeno se houver um sujeito no qual ele se situa ou que o vivencia (Fini, 1994).

A opção pelo referencial fenomenológico deu-se como a possibilidade de desvelar o significado da maternidade e paternidade subseqüentes vivenciadas pelos jovens na adolescência.

A fenomenologia investiga e descreve os fenômenos experienciados por um indivíduo, sem explicação causal, evitando pressupostos e preconceitos (Fini, 1994). Cada vez mais a fenomenologia tem sido 
utilizada na área da saúde, como um instrumento fundamental para estudos que desejam ampliar a compreensão dos fenômenos.

A fenomenologia não prioriza nem o sujeito, nem o objeto, mas a indissocialização de um e outro na própria estrutura da vivência da experiência intencional. O objeto é sempre para um sujeito que Ihe atribui significados (Pais, 2003).

Assim, preocupa-se com os significados dos eventos vividos pelos sujeitos e, por isso, vem ao encontro do propósito desta pesquisa, que é conhecer e compreender o fenômeno da recorrência da parentalidade na adolescência. Para Martins e Bicudo (1992) compreender é tornar explícito e transparente o que está oculto. Desse modo, busco as percepções que adolescentes pais e mães têm da maternidade/paternidade precoce recorrente. Espero que me relatem de modo preciso o que ocorre com eles ao vivenciarem a situação. Procuro uma qualidade diferenciada de suas percepções sobre a experiência.

Para Martins e Bicudo (1989), o objetivo da fenomenologia é a busca da essência do fenômeno que se mostra na descrição ingênua do sujeito. As descrições fenomenológicas referem-se às experiências vividas. É "ir à coisa nela mesma", desvelar o que está oculto e ampliar a visão daquele que olha o fenômeno para apreender peculiaridades ainda pouco compreendidas. Os indivíduos descrevem suas próprias experiências, em um determinado momento e com tal profundidade de detalhes que permitirão, posteriormente, tratamento sistemático e científico.

\section{3 Opção pelo referencial teórico-filosófico}

Diante das considerações apresentadas e, procurando ampliar o olhar sobre o fenômeno da maternidade e paternidade recorrente na adolescência, na perspectiva de adolescentes que são mães e pais recorrentes, declarando seus motivos para e por que, fui apropriando-me da fenomenologia compreensiva e social de Alfred Schütz com vista a 
organizar e conhecer o vivido dessas pessoas, no seu cotidiano como elementos que atuam, interagem e complementam-se dentro de um mundo chamado social.

Ao refletir a respeito da repetição da maternidade e paternidade precoces, busco compreender as experiências de ser adolescente mãe e pai e como ocorrem a maternidade e a paternidade repetidas nessa faixa etária, não me detendo exclusivamente na ação de um indivíduo, mas, no significado que esta ação projetada tem para o grupo envolvido.

Dessa forma, a fenomenologia social possibilita investigar não os comportamentos individuais, mas, sim, conhecer como se constitui um grupo social que vive em determinada situação típica.

Buscando na fenomenologia sociológica maior conhecimento para sustentação deste estudo, aproximei-me desse referencial por meio de leituras de obras clássicas de fenomenólogos como Schütz (1972, 1974a, 1974b); Wagner (1979); Capalbo (1996, 1998, 2000); e de pesquisadores que utilizaram esse referencial téorico-metodológico, entre eles: Merighi (1993); Tocantins (1993); Jesus (1998); Rodrigues (1998); Fustinoni (2000); Merighi (2000).

Assim sendo, minha escolha metodológica foi se estruturando como resultado de reflexões e leituras de obras que se apóiam na fenomenologia e na abordagem fenomenológica compreensiva e social.

O panorama apresentado preliminarmente evidenciou minha aproximação com o fenômeno da maternidade e paternidade repetidos na adolescência. Como pesquisador fenomenológico, porém, desvencilhei-me temporariamente de conceitos prévios, crenças, afirmações e teorias explicativas sobre o fenômeno estudado para ir como escreve Bruns (2000), "à coisa mesma" e, visualizá-la como se apresenta.

Ancorado no paradigma fenomenológico e baseado na premissa de que o humano experiência intencionalmente sua existência, atribuindo-lhe 
significados, busquei a compreensão do fenômeno da maternidade e paternidade precoces de repetição.

A seguir, passo a discorrer sobre o referencial filosófico que foi o fio condutor da análise dos dados do presente estudo. 


\section{O REFERENCIAL FILOSÓFICO DE ALFRED SCHÜTZ E SEUS CONSTRUCTOS}

Alfred Schütz era austríaco, nascido em Viena, em 1899; foi professor de Pesquisa em Sociologia na Universidade de Viena, além de exercer a Advocacia.

Em 1932, fez sua primeira publicação em língua alemã, a Fenomenologia do mundo social (Der sinhhafte aufbau der sozialen welt), na qual buscava dar à sociologia uma base filosófica quanto a seus fundamentos (Capalbo, 2000).

Em 1938, em razão da ameaça de ocupação da Áustria por Hitler e perseguição dos judeus, emigrou para França (Paris) e, em 1939, aos Estados Unidos da América. Neste país, lecionou no Departamento de Estudos Superiores de Ciências Políticas e Sociais da New School for Social Research de Nova York (Escola de Investigação Social de Nova York). Fundou a Sociedade Internacional de Fenomenologia, tendo participado do Conselho Editorial da revista Philosophy and Phenomenological Research (Walsh, 1972).

Em 1959, faleceu na cidade de Nova York aos 60 anos, antes de formular sistematicamente sua obra.

Suas obras póstumas publicadas nos Estados Unidos da América foram: The problem of social reality (1962) Studies in social theory (1964), Studies in Phenomenological Philosophy (1966) e The stuctures of life-world (1973).

Seu pensamento posterior à emigração, também, pode ser encontrado em sua obra reunida em três volumes e denominada, Collected papers, publicada nos Estados Unidos da América em 1960, que utilizei em parte no presente estudo (Capalbo, 2000). 
O propósito central do filósofo austríaco, afirma esta autora, foi estabelecer os fundamentos de uma sociologia fenomenológica.

Na América, Schütz tornou-se, o grande divulgador da fenomenologia de Edmund Husserl, sendo o grande articulador entre os conceitos da Fenomenologia proposta por Husserl e da Sociologia de Max Weber. Usou o pensamento desses autores, por meio de um processo de seleção e adaptação dos componentes relevantes de suas teorias, aprofundou-os e reestruturou-os criando uma nova vertente da Fenomenologia Sociológica. Esta apresenta como proposta a análise das relações sociais.

Portanto, seu pensamento é fundamentado na compreensão do mundo-vida, por meio das metodologias das Ciências Sociais; em contrapartida, às explicações deterministas das ciências naturais (0 positivismo). Estas excluem todo e qualquer aspecto subjetivo no trato com as coisas. Nelas não há preocupação com a experiência do sujeito, como ser engajado no mundo e co-participante dele.

Para o autor, cada relação tem características próprias, cujas ações são intencionais e possuem um significado para o ator. Para estudar as estruturas do mundo da vida cotidiana, partiu das experiências do ser.

No desenvolvimento desta pesquisa, optei por utilizar a abordagem fenomenológica da sociologia compreensiva de Alfred Schütz em razão de situar os indivíduos em sua atitude natural, permitindo captar a realidade social, ou seja compreender os indivíduos dentro de seu mundo-vida.

Para Schütz e Luckman (1977), a Sociologia deve começar por uma descrição das estruturas fundamentais do pré-científico, a realidade que parece evidente aos olhos do senso comum. Sublinham estes autores que esta realidade é o mundo da vida cotidiana. Esta realidade apresenta-se como um mundo de intersubjetividade; não posso existir na vida cotidiana sem interagir e comunica-me continuamente com outros. 
Pais (2003) refere que o cotidiano pode significar mais do que o sentido vulgar do termo; é o conceito que pode e deve ser tomado como fio condutor do conhecimento da sociedade. Este autor, escrevendo sobre o pensamento schütziano, cita que os fenômenos sociais objetivos devem ser vistos à luz da subjetividade dos atores sociais: quer no que se refere às atitudes, aos desejos, ou às definições de situação. Sem a consideração dos componentes subjetivos, as correlações objetivas são descrições artificiais da realidade.

Acredito que o referencial da fenomenologia social compreensiva de Schütz representa um esforço de investigação sistemática, um caminho para se compreender os aspectos sociais do fenômeno que me propus investigar, a maternidade/paternidade recorrente na adolescência.

A escolha deste referencial deu-se por ser um método intuitivo e descritivo que descreve a estrutura total da experiência vivida, incluindo o significado que essas experiências têm para os indivíduos que dela participam. Merighi (2000) contribui ao comentar que o significado é social, pois, ainda que este seja vivenciado individualmente num contexto objetivo de significação, encontra-se contextualizado na intersubjetividade, configurando um grupo social.

Inspirado, portanto, pela filosofia fenomenológica, busquei apreender a realidade social por meio do estudo do sentido da vida cotidiana, prestando especial atenção aos significados do mundo do sentido comum e, respeitando o discurso dos indivíduos que habitam esse mundo.

À medida que os significados vividos individualmente são contextualizados na relação intersubjetiva, vão configurando a relação social. Esses significados deixam de ser puramente individuais para configurar um sentido social (Jesus, 1998).

Só aquele que realiza e sente uma ação, única para ele, poderá dizer o que pretende, pois toda e qualquer ação é intencional, assim sendo 
possui um significado. Só o adolescente mãe/pai pode dizer como é ser adolescente mãe/pai recorrente em sua faixa etária. As significações nos remetem a uma situação de interação na vida cotidiana, na qual o mundo vivido torna-se mundo de experiências e conhecimento (Schütz, 1974a).

Influenciado pela Fenomenologia schütziana e valorizando aspectos do cotidiano, procurei compreender a situação social, tal como aparece aos adolescentes, tratando de transmitir o sentido que estes indivíduos têm da maternidade/paternidade precoce recorrente. Busquei, então, compreender a realidade desse fenômeno pelos olhos dos atores sociais (adolescentes pais/mães), analisando as práticas e os modos como constroem seu mundo social, ao mesmo tempo, que o fazem descritível, observável e objeto de informação.

Não parti de categorias de valores pré-constituídos em relação à realidade da vida cotidiana, mas, da descoberta de categorias dessa própria realidade por meio do discurso dos sujeitos.

Para a análise dos dados deste estudo, destaquei os seguintes construtos apresentados por Schütz (1972, 1974a; 1974b), a saber:

\section{1 O mundo da vida}

Alfred Schütz (1974a) diz que o mundo da vida, mundo da vida diária, mundo da vida cotidiana, mundo cotidiano, mundo do senso comum são as diversas expressões que indicam o mundo intersubjetivo experimentado pelo homem dentro do que Husserl denomina a atitude natural.

Este mundo já existia e de maneira organizada, quando nascemos é primordialmente o palco das nossas ações e interações; não só atuamos dentro do mundo, mas sobre ele. Conseqüentemente, o mundo do sentido comum é o palco da ação social; nele os homens entram em mútua relação e tratam de entender uns com os outro, assim como a si mesmos.

O sentido comum vê o mundo, atua nele e interpreta-o por meio de tipificações implícitas. Há um 
mundo social, existem os semelhantes que podem comunicar-se inteligentemente com outros, existem princípios muito vastos e gerais que são válidos para a vida cotidiana.

Continuando Schütz (1974a), refere que

o mundo da vida é desde o princípio, intersubjetivo. Pois vivemos entre semelhantes com os quais temos influências e experiências comuns, compreendendo-os e sendo compreendidos por eles. É também um mundo cultural, pois desde o princípio ele é um universo de significados para nós; uma textura de sentidos que devemos compreender para orientarmos e conduzirmos nele.

Os indivíduos e o senso comum são produtores de conhecimento, mas não de um conhecimento sociológico. É certo que a sociologia compreensiva propõe como meta prioritária, o maior esclarecimento possível do que pensa a respeito do mundo social de quem nele vive.

\section{2 Atitude natural}

Para o filósofo (Schütz, 1974a), a atitude natural é a maneira pela qual o homem experimenta o mundo intersubjetivo, seja o mundo do senso comum, mundo da vida diária ou mundo cotidiano. O mundo que recebemos ao nascer, é o palco de nossas ações e interações. Não só atuamos sobre, mas o interpretamos por meio de tipificações. Assim, a intersubjetividade é a categoria fundamental da existência humana.

Para Wagner (1979), a atitude natural é a postura mental que a pessoa toma no lidar espontâneo e de rotina com seus afazeres diários; é a base de sua interpretação do mundo da vida como um todo e em seus vários aspectos. O mundo da vida é o mundo da atitude natural. Nele, as coisas são tidas como pressupostos.

\section{3 Intersubjetividade}

A intersubjetividade é uma qualidade óbvia de nosso mundo e essa é a tipificação subjacente do senso comum. O homem é um ser de relações 
sociais, ele compartilha este mundo com outros. Para Schütz (1974a), a intersubjetividade é uma categoria fundamental para compreensão da existência humana no mundo, por meio dela é possível tomar as objetivações humanas como objeto de conhecimento, buscando as evidências dos processos conscientes e significados subjetivos dos atos e fenômenos do desenvolvimento histórico, no próprio homem que os constrói.

Capalbo (2000) refere que no entender de Schütz

o sujeito social, em sua ação social visando a mudanças, requer compreensão do fundamento da subjetividade, pois o mundo social não está lá fora como um objeto em si com características independentes dos indivíduos que as experimentam. $O$ mundo social é constituído através da comunicação e da ação intersubjetiva dos sujeitos empenhados nesta interação significativa.

O mundo do sentido comum, o mundo cotidiano, o mundo da vida são expressões do mundo intersubjetivo vivenciado, experimentado pelo homem na atitude natural. E interessa, sobretudo, mostrar que este mundo do sentido comum é o lugar da ação social, onde ocorrem as mudanças sociais (Capalbo, 2000).

\section{4 Situação biográfica}

Ainda que a realidade do sentido comum padronize toda ação social, cada indivíduo situa-se no mundo da vida de uma maneira própria, a isso Schütz (1974a) denominou sua situação biográfica.

O nascimento e o desenvolvimento biopsicossocial do ser humano transcorrem de maneira única para cada indivíduo. Schütz (1974a) declara que cada indivíduo segue sua vida interpretando tudo o que encontra no mundo, segundo a perspectiva de seus interesses particulares, motivos, desejos, aspirações, compromissos religiosos e ideológicos .

Para Schütz (1974a) a realidade do sentido comum nos é dada em formas culturais e históricas universais, entretanto o modo em que estas 
formas se expressam em uma vida individual depende da totalidade de experiência que uma pessoa constrói no curso de sua existência concreta.

\section{5 Acervo de conhecimentos disponíveis}

Segundo Schütz (1974a), a situação biográfica caracteriza-se fundamentalmente pelo fato de que o indivíduo dispõe, em qualquer momento de sua vida, de um acervo de conhecimentos disponíveis, integrado por tipificações do mundo do sentido comum. Uma sedimentação de experiências, desde a infância, vivenciada ou que ao indivíduo foi comunicada por outras pessoas, que este utiliza como técnicas para compreender ou, pelo menos, controlar aspectos de sua existência.

Só se pode compreender este acervo e as experiências vividas pelas ações exteriorizadas que constituem a base da comunicação e da relação social, essas ações ocorrem impulsionadas por motivos para e motivos por que, que serão tratados mais adiante.

\section{6 Ação}

Segundo Schütz (1974a), a ação é a conduta humana projetada pelo ator de maneira autoconsciente, ou seja, o sentido que a ação tem para o ator. Ela se origina na consciência do ator, por isso pode ser latente ou manifesta, projetada ou dotada de propósito. A ação está relacionada ao projeto no qual ela encontra seu significado.

Comumente distingue-se a ação da conduta, dizendo-se que a primeira é consciente e voluntária e a última reativa. Schütz cita que devemos examinar as razões mais profundas desta distinção, aparentemente superficial.

Assim, o filósofo afirma que a ação origina-se na consciência do ator, e é sempre voluntária e dirigida ao futuro. Ao contrário, na conduta não é peculiar esta orientação para o futuro. Esta orientação para o futuro é um 
conceito amplamente formulado por Husserl (Schütz, 1972; Schütz, 1974a; Schütz, 1974b).

A ação social (relação entre conduta ou vivências espontâneas) situa-se no tempo vivido e orienta-se para a conduta de uma ou mais pessoas agindo umas sobre as outras. A ação é interpessoal, surge da vivência interpessoal, como projeto participante.

A ação envolve, portanto, as dimensões da intencionalidade:

- intelectual: ela é sempre inteligente e tem um significado;

- volitiva: pois envolve o desejo de realizar, empenho, sentimentos, afeicões e temores;

- ativa: ela é voluntária; supõe o caminho da liberdade de escolha.

A ação não é guiada pela dimensão causal, ela nos leva aos motivos para os quais estamos voltados para o outro, visando algo, portanto, é um projeto.

\section{7 Teoria da motivação}

Para Schütz, segundo interpretação de Capalbo (1998), o mundo da vida é intersubjetivo desde o início e as nossas ações nele exercidas são eminentemente sociais, pois elas nos colocam em relação uns com os outros. O nível mais fundamental desta relação dá-se na situação face a face. É aí que a intersubjetividade aparece em toda sua densidade e que o outro nos aparece em sua unidade e em sua totalidade.

Entretanto, a ênfase principal encontra-se na questão da ação humana que é planejada baseada em um projeto que se pretende realizar.

Para compreender os impulsos que estão atrás da ação humana, vamos ao encontro da teoria da motivação de Schütz. O filósofo declarou que as pessoas agem em função de motivações dirigidas a objetivos que apontam para o futuro: os motivos para/ motivos a fim de - uma categoria essencialmente subjetiva. Declara também que as pessoas têm razões e preocupações para suas ações que são os motivos por que. Essas razões 
estão enraízadas em experiências vividas, no acervo de conhecimento adquirido e transmitido pelos predecessores, como herança cultural, assim como outros conhecimentos resultantes da experiência pessoal.

Os motivos para referem-se ao estado de coisas a ser estabelecido, para atingir o projeto a realizar e à vontade de fazê-lo. Os motivos por que se prendem ao passado sedimentado, à situação em que o ator já possui conhecimento disponível, a saber, os gostos, inclinações, preferências, conceitos, preconceitos que irão condicionar o projeto (Capalbo, 1998).

Continuando a análise do pensamento schütziano, Pais (2003) relata que a atenção dirigida às intenções e aos motivos que levam os indivíduos a interagir devem estar presentes, na descrição e interpretação dessas estruturas do mundo da vida. Para ter acesso a essas estruturas, não podemos adotar apenas uma posição de observador "externo" que somente vê as factualidades objetiváveis e mensuráveis. Devemos, também, desenvolver categorias para entender a interpretação que os indivíduos dão aos significados dos fluxos latentes de sua vida cotidiana.

\section{8 Relação face a face}

Neste conceito, o filósofo austríaco (Schütz, 1972) cita que uma outra pessoa está dentro do alcance de minha experiência direta e que compartilha comigo uma comunidade de espaço e tempo. Isto acontece quando ela está presente pessoalmente e estou consciente dela como pessoa. Percebo seu corpo como campo sobre o qual se manifestam os sintomas de sua consciência íntima. Ela divide comigo um tempo comum, quando sua experiência flui lado a lado com a minha, quando posso a qualquer momento buscar e captar seus pensamentos, conforme eles existam. A situação face a face pressupõe, então, uma simultaneidade real de cada uma das correntes de consciências distintas.

Na relação face a face, acrescenta Rodrigues (1998), eu apreendo o outro de maneira mais viva, talvez mais direta do que aquela com que eu 
posso apreender: o meu sentir, pensar e agir. A relação social decorre de uma reciprocidade de intenção de conhecer o outro como ser humano, vivo, consciente e livre.

Interpretando, também, este construto, Silva e Rodrigues (1996) dizem que é na relação face a face que apreendo diretamente o outro, em um momento de interação social, em uma relação nós. Numa experiência direta entre pessoas que só se realiza quando existe comunhão de espaço e tempo.

A fenomenologia social de Schütz visa a compreender o mundo com os outros em seu significado intersubjetivo. Ela trata da estrutura de significados na vivência intersubjetiva da relação social do face a face (1972; 1974a; 1974b).

No que se refere à recorrência da maternidade/paternidade adolescente, para uma assistência adequada acredito que os profissionais de saúde deverão atender as necessidades dos adolescentes, para isto, é preciso conhecê-los, compreendê-los, não teoricamente, não por meio de modelos preestabelecidos, mas, entender suas reais demandas, relatadas por eles mesmos.

\section{9 Tipificação}

Na relação vivida simultânea, direta ou na relação com nossos contemporâneos, vivemos baseados nos tipos que se estabelecem nessa relação e não como únicas e singulares. As pessoas criam tipos no mundo do senso comum, de acordo com seus próprios critérios, subjetivamente, significativos, baseados em suas percepções e definições. O tipo não é o fruto da conduta particular de alguém, puramente individual, mas é um tipo vivido que constitui uma certa convivência simultânea, social uma característica típica daquele grupo social que está vivendo aquela situação de comportamento vivido. 
O mundo cotidiano apresenta-se nas tipificações, ou seja, as representações ou caracterizações construídas pelos próprios atores sociais, de acordo com suas relevâncias. Essas tipificações incluem o universo e o estável, o específico e o mutável. O ator social tipifica o mundo para compreendê-lo e comunicar-se com seus semelhantes (Schütz, 1972).

Capalbo (2000) ao aproximar a faculdade de perceber a ação humana, não como mera conduta reativa, mas, anexada ao significado da experiência vivida, justificada na concepção de intencionalidade, baseada nos construtos apresentados por Alfred Schütz sobre tipificação e tipo ideal, desenvolve seus estudos com a inquietação proveniente de compreender o significado subjetivo da ação, o que irá possibilitar construir o tipo vivido. $\mathrm{O}$ tipo vivido para Capalbo é, a expressão de uma estrutura vivida na dimensão social, uma característica de um grupo social. Um conceito expresso pela inteligência, cuja natureza vivida é essencial, é invariante. E chega-se ao tipo vivido a partir da análise das relações sociais.

Neste sentido, a identificação da estrutura comum dos significados conferidos a determinada ação ou ato pode ocorrer, quando estes são reduzidos a seus motivos típicos. Para Schütz (1972), pode-se reduzir a ação ou ato do outro a seus motivos típicos, incluindo suas referências a situações, finalidades e meios típicos. É suficiente encontrar motivos típicos de atores típicos que explicam o ato como típico a partir de uma situação típica.

Na interpretação de Fustinoni (2000), a tipificação

é um meio de se chegar a um acordo com o mundo e não descreve, na realidade, suas qualidades reais. Os tipos não existem por si mesmos, sob forma pura e simples, mas são conceitos relativos que expressam motivos particulares e interesses de indivíduos específicos, que definem seus ambientes e dão significado ao mundo. São formados como conseqüências de certos problemas que preocupam uma determinada pessoa num determinado momento, e variam conforme a temática dos problemas. 
Para Capalbo (1998), quando oriento minha ação em direção a alguém,

eu atribuo um conjunto de motivos em vista dos quais vou agir. Para tal recorro ao meu acervo de conhecimentos, no qual tenho tipificações de meus semelhantes, atribuindo-Ihes conjuntos típicos de motivos variáveis em razão dos quais e em vista dos quais eles agem. Em toda interação social do tipo face a face, então, atribuem-se motivos típicos aos indivíduos com os quais estamos em relação.

A tipicidade, portanto, desempenha papel importante na compreensão do outro e na interação social.

A interpretação subjetiva do significado, para Silva e Rodrigues (1996),

é uma tipificação, nela o pesquisador capta as convergências nas intenções do sujeito da pesquisa, ou seja, nos motivos para peculiares a serem alcançados em sua ação, possibilitando a construção do tipo vivido, essencial à compreensão do típico da ação. Ou seja, o tipo vivido é construído pelo agrupamento dos motivos para invariáveis, de um grupo de atores específicos, com ações específicas, que se dão num determinado contexto, no cotidiano do mundo social.

Wagner (1979), citando Schütz, refere que a tipificação transforma ações individuais únicas, de seres humanos únicos, em funções típicas, e papéis sociais típicos, que se originam de motivações típicas e têm como objetivo realizar fins típicos.

Temos disponível, um acervo de conhecimentos herdado de nossos predecessores, ao qual acrescentamos nossa própria experiência vivida. E eu só posso compreender esta experiência vivida pelas ações exteriorizadas, que constituem a base da comunicação e da relação social, estas ações ocorrem impulsionadas por motivos para e motivos por que (Schütz, 1974a). 
A obra de Alfred Schütz está fundamentada na valorização dos sujeitos; portanto, busquei conhecer a vivência dos adolescentes em relação à maternidade/paternidade recorrentes na adolescência.

Considerando a parentalidade repetente na adolescência, como uma ação que se desenvolve em vista de um projeto que traz em si motivos para, busquei saber como esta ação é tipificada, segundo os motivos dos sujeitos.

Procurei conhecer o cenário da parentalidade precoce e compreender como os adolescentes "colocam-se em cena" e como elaboram suas "imagens-ação" e quais tipificações passam por seus discursos.

A assistência à saúde dos adolescentes implica o encontro de pessoas, é uma experiência intersubjetiva. Assim sendo, penso que as ações oferecidas pelos profissionais de saúde devam responder às expectativas dessa clientela.

É, portanto, no contexto das concepções de Schütz, já descritas, que busquei a compreensão do significado da ação e as necessidades do adolescente pai/mãe recorrente. Neste contexto, pretendo que o presente estudo possibilite reflexão sobre a assistência preestabelecida em programas de saúde, oferecida aos adolescentes e as necessidades de cuidados relacionadas a seu mundo vida, que emergem desta própria clientela. Para isto, apoio-me na Sociologia compreensiva de Alfred Schütz por permitir captar a realidade social e as necessidades na atitude natural, isto é, por situar as necessidades assistenciais (relacionadas à maternidade e paternidade recorrentes nesta faixa etária), centrada nos clientes (os adolescentes), baseada neles próprios e não em afirmações feitas a priori. 


\section{PROCEDIMENTO METODOLÓGICO}

\section{1 Sujeitos da pesquisa e região de inquérito}

A fim de desvelar, conhecer e compreender o fenômeno da maternidade/paternidade recorrente na adolescência, as inquietações foram dirigidas às descrições das vivências dos adolescentes pais e mães.

Para efeito deste estudo adotei o conceito de adolescência da Organização Mundial de Saúde (OMS, 1989) que considera adolescente o indivíduo que se encontra entre dez e vinte de idade e que, também, coincide com o conceito do Programa de Saúde do Adolescente - Prosad (Brasil, 1989; 1996; 2002b).

Segundo Merighi (1993), a região de inquérito é o local transparente de minhas preocupações, como pesquisador, em que é possível determinar aquilo que deve ser feito. Não é, portanto, um espaço, mas um contexto conceitual no qual as pessoas agem.

Para definir a região de inquérito, levei em consideração o fato dos sujeitos serem adolescentes, ou seja, estarem, entre dez e vinte anos e serem pais e mães recorrentes. Portanto, o critério de inclusão foi a vivência da repetição da maternidade / paternidade na adolescência.

É necessário esclarecer que, ao definir a região de inquérito, não considerei profissão, situação socioeconômica nem nível de escolaridade por acreditar que estes dados não interfeririam no experienciar a maternidade / paternidade recorrente, uma vez que meu interesse foi a experiência vivida pelos sujeitos.

Neste estudo, a região de inquérito foi, portanto, a própria situação em que ocorreu o fenômeno, o mundo-vida, o pré-reflexivo de cada adolescente pai ou mãe recorrente. 
A abordagem inicial dos sujeitos deu-se no Ambulatório de Ginecologia e Obstetrícia e na Clínica Obstétrica do Hospital Ipiranga (SP), mediante autorização da instituição (Anexo II e VI). Vale acrescentar que, como forma de ampliar o universo das experiências, a aproximação com os demais sujeitos também foi feita por meio de indicação dos primeiros adolescentes entrevistados nos locais acima referidos.

O número de sujeitos que fez parte da pesquisa, não foi definido previamente, mas, sim, com base nas descrições obtidas nos depoimentos. Desta forma, quando os dados foram repetindo-se, mostrando sinais de desvelamento do fenômeno, decidimos que era o momento de parar a coleta.

Desse modo, foram entrevistados 23 adolescentes pais/mães recorrentes, sendo seis pais e 17 mães, dentre as entrevistas selecionadas para a análise, foram apenas cinco pais e dez mães por serem seus discursos ricos de significados e suficientes para desvelar o fenômeno investigado.

\section{2 Descrição do processo de coleta de dados}

A coleta de dados foi feita no período de julho a setembro de 2005, sendo estes obtidos por meio de depoimentos, estratégia utilizada pela pesquisa qualitativa. Foram gravados, mediante autorização dos participantes e norteados por um roteiro constituído de questões abertas. Alguns depoimentos aconteceram no próprio Ambulatório de Ginecologia e Obstetrícia da instituição acima mencionada, onde existe espaço disponível, outros aconteceram em locais combinados, conforme a conveniência dos entrevistados.

As seguintes questões nortearam a entrevista com os adolescentes:

- Como foi para você ser mãe/pai pela primeira vez?

- Como aconteceu o nascimento do outro filho?

- Como é ser mãe/pai mais de uma vez, ainda adolescente?

- O que você espera do futuro sendo mãe/pai tão jovem? 
Cabe salientar que não houve ordem rígida para formular as questões, permitindo aos adolescentes a livre exposição de relatos sobre o tema proposto com base em suas vivências.

Tomou-se o cuidado de proporcionar aos adolescentes a liberdade e a espontaneidade necessárias para relatar suas experiências de maneira ampla e equilibrada para que pudessem descrever de forma mais precisa possível o ocorrido com eles ao viverem essa experiência e o que pensam sobre o futuro.

\section{3 Questões éticas}

Este estudo obedeceu às normas regulamentadoras da Resolução 196/96 do Conselho Nacional de Saúde (CNS, 1996), que trata de pesquisas envolvendo seres humanos. Nesse sentido, buscamos resguardar o anonimato e o sigilo em relação à gravação e utilização dos depoimentos, devolução dos resultados e sua divulgação, para assegurar a inexistência de prejuízos aos participantes deste estudo.

Para tal, antes de realizar cada entrevista, apresentei o objetivo do estudo e o Termo de Consentimento Livre e Esclarecido, para que os entrevistados pudessem assinar, caso concordassem conceder seus depoimentos (Anexo I). Por se tratar de adolescentes, a assinatura no referido termo, também, foi realizada por uma testemunha ou pelo responsável legal do interessado.

Assim, os sujeitos tiveram liberdade de querer ou não participar, sendo-Ihes assegurado o direito de declinar da participação a qualquer momento, se assim fosse sua vontade, sem qualquer tipo de sanção moral, econômica ou de qualquer outra natureza, podendo fazê-lo antes, durante, ou mesmo, depois da obtenção dos depoimentos.

Além disso, a identificação dos participantes do estudo foi feita com pseudônimos a fim de assegurar-Ihes o anonimato, sendo adotada a identificação por meio de nomes dos minerais preciosos (Anexo III). Os 
discursos dos sujeitos encontram-se na íntegra no anexo IV, com uma breve caracterização de cada adolescente pai/mãe.

Este projeto de pesquisa foi submetido a uma avaliação do Comitê de Ética em Pesquisa da Escola de Enfermagem da Universidade de São Paulo, obtendo o parecer positivo (Anexo V).

Vale destacar que depois da aprovação do Comitê de Ética em Pesquisa foi feito um estudo preliminar a fim de averiguar a pertinência das questões norteadoras. Após constatar que os depoimentos responderam a essas questões norteadoras, os dados passaram a ser colhidos.

\section{4 Momento da análise compreensiva}

Para proceder a análise individual dos discursos, percorri os caminhos dos pesquisadores da Fenomenologia Social, como: Tocantins (1993), Rodrigues (1998), Jesus (1998), Merighi (2000), Fustinoni (2000), adaptando-os ao presente estudo.

O percurso para a análise compreensiva do fenômeno foi desenrolado gradativamente, da seguinte maneira:

- leitura atenta e pormenorizada dos discursos dos adolescentes, objetivando a apreensão da vivência motivada dos sujeitos participantes;

- agrupamento dos aspectos significativos extraídos dos discursos que representaram convergências de conteúdo dos relatos que compõem as categorias;

- releitura das transcrições, buscando identificar categorias concretas, ou seja, locuções de efeito que expressassem aspectos significativos da compreensão e vivência dos motivos para os adolescentes repetirem a maternidade e paternidade precocemente; 
- identificação de categorias concretas que abranjessem os atos dos sujeitos participantes;

- estabelecimento dos significados do ato social frente à paternalidade adolescente recorrente, pelo típico dos discursos dos sujeitos participantes, para obter a tipologia vivida;

- a análise compreensiva dos agrupamentos de significados, segundo o pensamento do fenomenólogo Alfred Schütz, foi o fio condutor na discussão da análise dos dados.

Antes de apresentar a análise compreensiva dos depoimentos dos adolescentes, a fim de melhor elucidar o leitor da trajetória da presente pesquisa, passo a representar graficamente os esquemas representativos do estudo já descritos. 


\section{ESQUEMAS REPRESENTATIVOS DO ESTUDO}

\section{1 Esquema da pesquisa}

O DESPERTAR PARA O ESTUDO

\section{OBJETIVO}

Conhecer e compreender como é constituída a percepção dos adolescentes em relação à recorrência da maternidade / paternidade na adolescência.

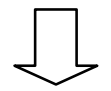

\section{INQUIETAÇÕES}

- Como os adolescentes que são pais ou mães experienciam a maternidade / paternidade?

- Como é para eles passar por esta experiência quando ainda se é jovem?

- Como é experienciar a maternidade/paternidade mais de uma vez quando ainda se é jovem?

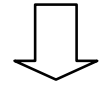

\section{QUESTÕES NORTEADORAS DA ENTREVISTA}

Aos adolescentes mães/pais recorrentes:

- Como foi para você ser mãe/pai pela primeira vez?

- Como aconteceu o nascimento do outro filho?

- Como é ser mãe/pai mais de uma vez, ainda adolescente?

- $\quad$ o que você espera do futuro sendo mãe/pai tão jovem? 


\section{2 Esquema da metodologia}

\section{PERCORRENDO A TRAJETÓRIA METODOLÓGICA}

- Pesquisa de natureza qualitativa

- Referencial teórico-filosófico: Fenomenologia Social de Alfred Schütz

- Referencial de análise: pesquisadores da Fenomenologia social

- Leitura minuciosa de todos os discursos

- Discriminação das unidades de significado

- Identificação das categorias concretas

- Análise das descrições à luz do referencial da Fenomenologia Social

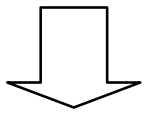

\section{OBJETO}

Discurso de pais / mães adolescentes

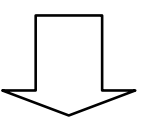

\section{REGIÃO DE INQUÉRITO}

- Vivência da maternidade e paternidade recorrente na adolescência

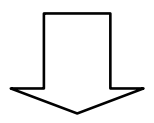

\section{SUJEITOS DA PESQUISA}

- Adolescentes mães recorrentes

- Adolescentes pais recorrentes
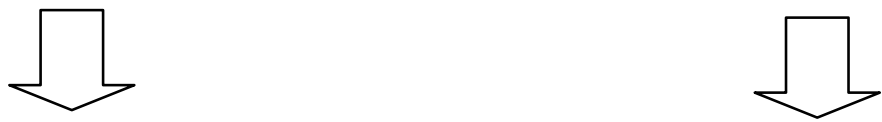

\section{OBJETIVO}

- Conhecer e compreender como é constituída a percepção que os adolescentes têm da maternidade/paternidade recorrente na adolescência 


\section{3 Esquema da fenomenologia de Alfred Schütz}

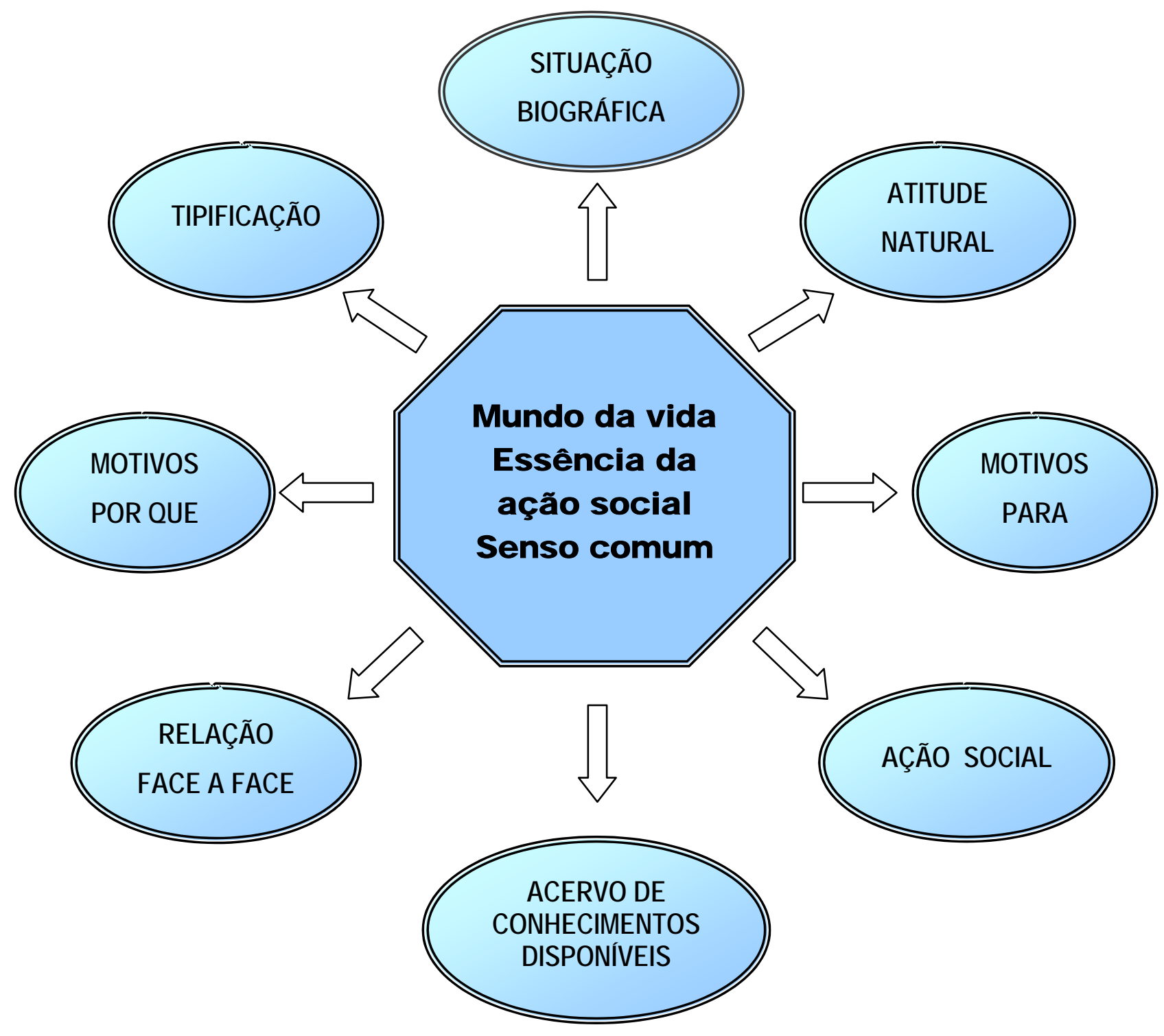




\section{CATEGORIAS CONCRETAS EMERGIDAS DO VIVIDO}

\section{A vida só pode ser compreendida olhando-se para trás, e só pode ser vivida olhando-se para frente. Sören Aabye Kierkegaard}

Na leitura atenta e pormenorizada de cada relato, procurei identificar 0 sentido global da experiência da paternidade e maternidade adolescente recorrente. Em leituras subseqüentes, agrupei as convergências temáticas e apreendi o significado que os sujeitos da pesquisa atribuíram às suas próprias ações.

A construção dos significados das ações dos adolescentes foi contextualizada em seus discursos, com base nas experiências por eles vividas no mundo cotidiano, possibilitando construir as categorias concretas emergidas do vivido.

Lendo e relendo os depoimentos, percebi que não havia diferenças significativas entres as falas dos pais e mães adolescentes. A maneira de vivenciar a parentalidade recorrente era comum a estes adolescentes, com algumas variações próprias dos gêneros, constituindo, assim, o mesmo tipo vivido. Tornou-se, então, mais adequado realizar a análise compreensiva de todos os depoimentos em conjunto.

Ao reexaminar cuidadosamente os conteúdos dos discursos, notei que os mesmos convergiam para sete unidades temáticas que, em segundo momento, sofreram novamente o processo de convergência, confluindo para cinco grandes categorias concretas do vivido: Contextualizando a percepção sobre ser pai/mãe adolescente, abrangendo duas subcategorias: Sendo pai/mãe pela primeira vez e pai/mãe recorrente; Vivenciando perdas; Vivenciando ganhos, com duas subcategorias: sentindo-se amadurecidos/responsáveis e expressando satisfação com a 
parentalidade; Buscando segurança para o futuro; e Experienciando situação ambivalente.

As três primeiras categorias referiram-se aos motivos por que: à realidade vivida pelos sujeitos deste estudo, ao contexto motivacional e as duas últimas aos motivos para da ação, ou seja, aos projetos, ao que se pretende alcançar.

$\mathrm{Na}$ análise dos discursos, considerei o constructo de intersubjetividade que, para Schütz (1974a), é uma categoria fundamental para a compreensão da existência humana, pressupondo a troca de experiências subjetivas entre as pessoas. Não se referindo, portanto, ao indivíduo único em sua singularidade, mas, ao que é comum a várias pessoas. Por meio dela, foi possível tomar as objetivações humanas, como objeto de conhecimento, construído pelo próprio homem. Assim, as pessoas percebem-se como semelhantes, podendo atuar umas sobre as outras, compreender e ser compreendido por outros, caracterizando a intersubjetividade do mundo da vida, lugar da ação social onde ocorrem as mudanças sociais.

A interpretação da ação de ser pai/mãe adolescente recorrente foi baseada na intersubjetividade de cada adolescente, pai ou mãe, sendo correspondente aos elementos de sua situação biográfica.

De acordo com o constructo de situação biográfica de Schütz, entendo que cada adolescente tem sua maneira própria de inserir-se no mundo da vida, revelando seu modo de posicionar-se no cenário da ação e de atuar, ou seja, o modo pelo qual ele/ela interpreta sua condição de pai/mãe recorrente, vislumbra possibilidades e envolve-se em seus desafios.

A situação biográfica caracteriza-se pelo conjunto de conhecimentos que integram o patrimônio individual dos adolescentes, tanto o que vivenciaram quanto o que Ihes foi transmitido por seus predecessores. Isto é, o que Schütz (1974a) denominou acervo de conhecimentos 
disponíveis, cuja situação biográfica é a base para o significado que o indivíduo atribui à ação.

Assim, o enfoque, encontra-se na ação humana ou social, sendo possível compreender esta ação subjetiva pelos seus motivos - motivos para e por que. 


\section{CONSTRUÇÃO DO TIPO VIVIDO}

Aqueles que se prendem ao passado, perdem o futuro que nos guia. Winston Churchill

Ao examinar as categorias emergentes reveladas neste estudo, foi possível construir o tipo vivido dos adolescentes em relação à parentalidade recorrente na adolescência .

Assim, é necessário salientar novamente que o tipo vivido é um constructo elaborado pela reflexão sobre a vivência do sentido comum que se verifica em um determinado contexto, no cotidiano do mundo social.

Ao tratar da interpretação científica da ação humana, Schütz (1974a) declara que todo conhecimento existente, tanto na esfera do sentido comum como no pensamento científico, implica constructos, ou seja, abstrações, generalizações, formalizações e idealizações próprias relacionadas a um certo nível de organização do pensamento. Portanto, os fatos são sempre interpretados pelas atividades de nossa mente e, assim, podemos captar determinados aspectos da realidade do mundo.

Esses constructos de segundo nível são elaborados e baseados nas ações que foram vivenciadas, no primeiro momento, pelos sujeitos envolvidos.

Nesta perspectiva, o tipo vivido desses adolescentes constitui uma característica do grupo que está vivenciando um mesmo fenômeno, ou seja, a parentalidade repetida nesta faixa etária.

À luz dos pensamentos de Schütz (1974a), desvelo que o mundo cotidiano dos adolescentes em relação à repetição da parentalidade apresenta-se nas representações ou caracterizações (tipificações) construídas pelos próprios adolescentes, de acordo com suas relevâncias. 
A tipificação vai se tornando progressivamente anônima, conforme se afasta de sua origem fundante que reside na situação face a face. Ela transforma, então, aquelas ações individuais, únicas, singulares em funções típicas de papéis sociais típicos, originários de motivos típicos, tendo como objetivo uma realização típica. As tipificações incluem todo um contexto social, pois os adolescentes, como atores sociais, tipificam o mundo para compreendê-lo e comunicar-se com seus semelhantes (Capalbo, 2000).

Elaborei e passo, então, a apresentar o tipo vivido - pai e mãe adolescente recorrente, em consonância com os constructos de Alfred Schütz e as categorias emergentes originárias dos motivos para e motivos por que dos adolescentes.

Desse modo, os adolescentes percebem-se pai/mãe mais de uma vez, retratando um tipo vivido que experiência perdas e ganhos: percebemse maduros, responsáveis, preocupados com o cuidado e a educação dos filhos, almejando segurança para o futuro. Motivo que os leva a buscar trabalho, moradia própria, retomada dos estudos, estabilidade conjugal e construção de uma família.

Vivenciam uma situação de ambivalência entre o que desejam e a realidade vivida, pois, pelo fato de serem pais/mães adolescentes lastimam ter perdido a liberdade. 


\section{ANÁLISE COMPREENSIVA DO TIPO VIVIDO: ADOLESCENTES PAIS E MÃES RECORRENTES}

\section{CONTEXTUALIZANDO A PERCEPÇÃO SOBRE SER PAI OU MÃE ADOLESCENTE}

Pela motivação dos adolescentes, compreendi os significados de suas ações, pois estas não são impostas, mas, oriundas de algo que os próprios sujeitos vivenciaram como relevantes.

Conforme abordado anteriormente, a motivação por que serve para contextualizar, motivar a ação futura. Nela está imbutido o acervo de conhecimentos acumulados transmitidos pelos predecessores, a herança cultural com a história pessoal. Apesar da motivação por que estar enraizada em experiências passadas, os atores não a tem consciente, enquanto atuam. Estes só podem compreendê-la em reflexão retrospectiva, que pode ocorrer, ainda que não necessariamente, depois de terminado o ato. Entretanto, um pesquisador poderá ser capaz de reconstruí-la com base no ato consumado.

Partindo das considerações mencionadas, realizei a análise compreensiva das categorias, oriundas do típico da vivência dos adolescentes, extraídas de seus depoimentos.

As categorias concretas emergidas do vivido e as subcategorias extraídas dos depoimentos dos sujeitos envolvidos no estudo, estão apresentadas na seqüência, assim como seu esquema representativo. 


\section{- Subcategoria: Sendo pai / mãe pela primeira vez}

Até pouco tempo nas sociedades tradicionais, a parentalidade só era bem aceita quando a união do casal era reconhecida socialmente com todos os preparativos, permitindo uma reflexão e uma organização prévias desse evento. Mas, na atualidade, observamos uma "naturalização da parentalidade adolescente, assim como de sua repetição (Clerget, 2004).

A visão tradicional sobre adolescentes pais/mães perpetua esteriótipos negativos e atrapalha o reconhecimento de muitos que desempenham adequadamente as funções parentais, prestando um bom cuidado a seus filhos.

Arenson (1994) explorou as percepções de mães adolescentes sobre a maternidade adolescente, verificou surpreendente nível de firmeza e comprometimento das adolescentes com as crianças e um desejo de otimizar a segurança financeira por meio do trabalho árduo e posterior, formação educacional. Inesperadamente, estas mães descreveram o fato de ter filhos como uma força positiva que as ajudou na conversão de suas vidas passadas de autodestruição para vidas mais produtivas e futuro cheio de esperança.

Examinando as falas dos adolescentes, capto nos relatos uma certa estranheza, um encantamento, surpresa e a satisfação em relação ao nascimento de seus filhos:

Eu adorei! Adorei porque eu já estava planejando, já estava tendo um relacionamento com ele. Eu namorava ele desde os 12 anos e a gente já estava morando junto. ÁGUA-MARINHA

... Quando nasceu [o primeiro] foi uma surpresa, assim, aquele momento que você vê a criança, assim, lá no berçário ... é uma coisa inexplicável, né? O meu coração acelerou, as lágrimas caíram, é uma emoção, fora do comum. TOPÁZIO

Ah!, achei meio estranho ... primeiro filho ... a gente fica assim ... como vou cuidar, mas é normal! CRISÓLITO

... Eu fiquei um pouquinho assustada ... no começo ... ESMERALDA 
9.1 Esquema representativo do típico da vivência dos adolescentes pais e mães recorrentes

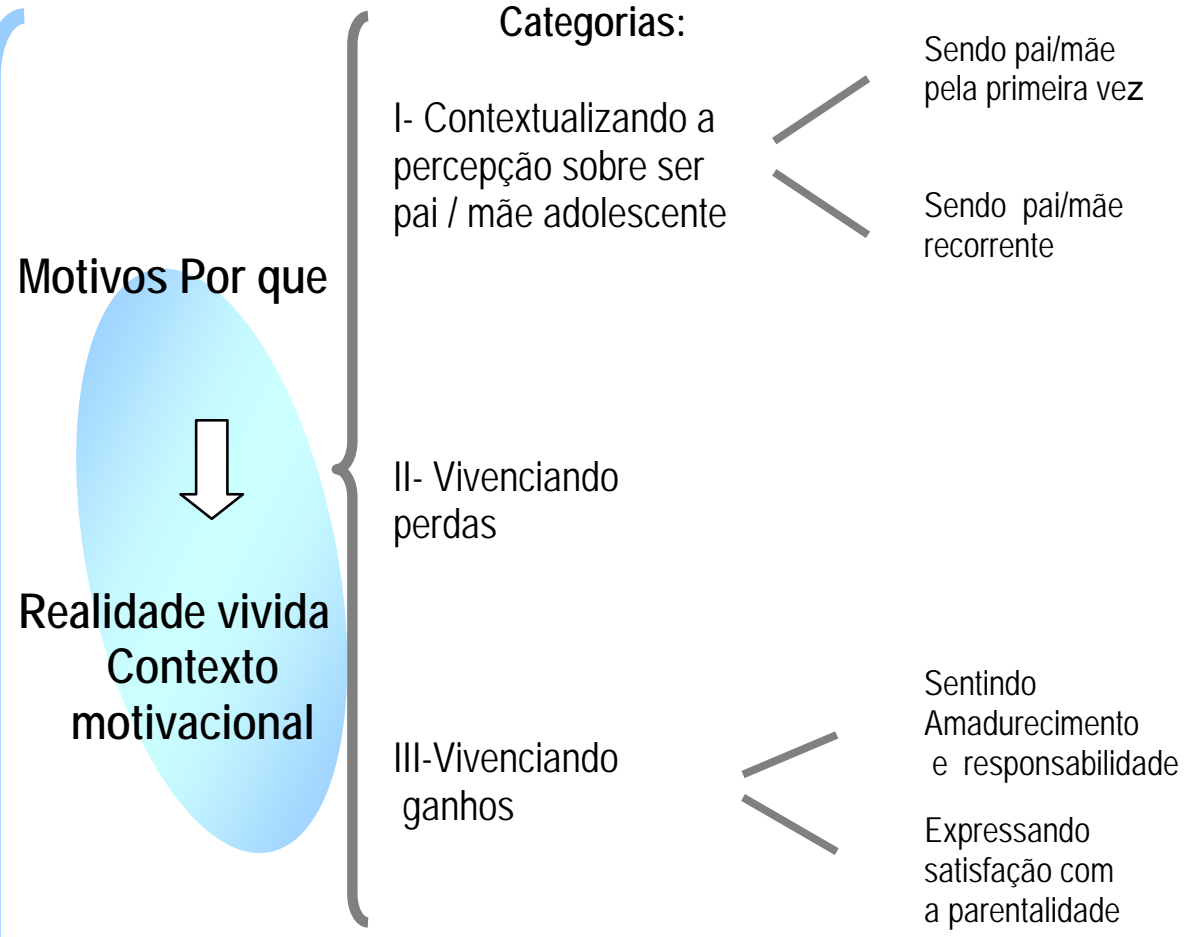

Ação Social

Ser pai / mãe adolescente recorrente
Motivos Para<smiles>C1CCCCC1</smiles>

Projetos:

0 que se pretende
Solicitude pelo cuidado e educação dos filhos

IV- Buscando segurança para o futuro

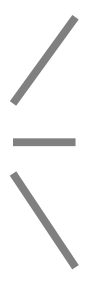

Busca de trabalho, moradia própria e retomada dos estudos

Desejo de estabilidade conjugal e construção de uma família

Desejo de ser pai/mãe $X$ não desejo de ter mais filhos

V- Experienciando situação de ambivalência
Ter filhos cedo é bom $X$ não aconselha a tê-los

Ter filhos é bom, tornam-se responsáveis $X$ perdas 
Alguns autores acreditam que a idade dos jovens representa um fator de aceitação social da maternidade e paternidade, porém existem estudos relacionados mais a fatores socioculturais que à idade. Nesse sentido, as mães, com idades entre 13 e 17 anos, apresentam características mais desfavoráveis se comparadas com aquelas mães, entre 18 e 19 anos (Fávero et al., 1997; Luz, 1999; Martins, 1999; Galarza, 2000; Sari, 2002; Levandowski, 2004). Entretanto, não foram encontradas diferenças entre as variáveis de comportamento de mães adolescentes e adultas. Observou-se, sim, que existe correlação íntima entre o comportamento materno de mães adolescentes e sua situação conjugal (Linares et al., 1998).

... Meu medo, é ter outro baque, tipo, se separar de novo ... o primeiro filho com o pai distante ... o segundo com o pai distante ... estou disposta a enfrentar o que vim ... TURMALINA

... meu marido fica do meu lado, então, isso ajuda mais. A gente fica mais segura pra criar ele e tudo. $\mathbf{R U B I}$

... agora, tudo bem ... esse eu já quis ... foi tudo bem ... eu também quis porque o pai, ele, também assumiu, registrou. MARCASSITA

Embora pesquisas posteriores sejam necessárias, os resultados deste estudo revelam pais e mães adolescentes, como um grupo social mais heterogêneo do que tem sido previamente descrito.

Constato que a homogeneidade e os padrões tipificados da gravidez e parentalidade na adolescência, descritos em muita literatura científica, não encontram respaldo nas falas dos adolescentes sujeitos desta pesquisa, mesmo porque vivemos em um País de grande heterogeneidade social e regional.

As vivências e transformações dos adolescentes são individuais, devendo ser compreendidas dentro de seu próprio mundo vida, na sua atitude natural, de acordo com sua situação biográfica e não em um conceito cronobiomédico, de maneira massificada como ocorre com grande parte do conhecimento científico atual sobre a progenitura adolescente. 
Schütz (1974a) declara que ainda que a realidade social padronize toda ação social, cada indivíduo situa-se no mundo da vida de uma maneira própria, sendo esta sua situação biográfica.

Aquino et al. (2003) comentam que a gravidez (ouso incluir também a parentalidade) é vivida de múltiplas formas que os contextos sociais definem universos de possibilidades e significações diferentes entre os jovens de distintas classes.

$\mathrm{Na}$ abordagem deste tema, temos enfatizado o risco para a gestação/parto, a situação socioeconômica desfavorável e a incapacidade psicológica dos adolescentes para criar os filhos, ou ainda, considerando a parentalidade nesta fase pela ótica da falta de informação, descuido, rebeldia e inconseqüência dos jovens.

Uma crítica a pesquisas que associam a parentalidade adolescente com repercussões negativas na criação dos filhos é que, geralmente, não se considera que as crianças observadas sejam as primogênitas e que a primeira parental costuma ser difícil, mesmo para pais adultos (Parceval, 1986).

Contrariamente à visão pessimista da literatura e da sociedade, alguns discursos apontaram diferentes percepções da maternidade e paternidade pelos progenitores.

Out e Lafrenière (2001) mencionam vários estudos, nos quais se demonstram que os adolescentes subestimam as demandas envolvidas na parentalidade e tendem a perceber mínimas conseqüências sociais negativas associadas à gravidez adolescente.

De acordo com Gordon (1990); Gordon (1996), existe pouca capacidade dos adolescentes refletirem sobre perspectivas que possam estar relacionadas a seu fracasso ao utilizar métodos anticoncepcionais. Desse modo, os que demonstram dificuldade em imaginar-se como pais, podem não considerar uma gravidez não planejada como conseqüência 
potencial da relação sexual desprotegida ou não perceber a gravidez, como um evento negativo.

A percepção da maternidade de maneira positiva é identificada neste estudo e também em outros, como: (Arenson, 1994; Madeira e Tsucheniro, 2000; Folle e Geib, 2004; Silva e Tonete, 2006, entre outros), conforme as falas apresentadas adiante. Parece haver uma busca de estabilidade revelada por meio da percepção do filho como algo próprio, um bem. Isto pode revelar uma tentativa de obter autonomia, atingir a maturidade e perceber sua própria competência para cuidar do filho:

Foi bom! Não foi planejado, mas, foi bom! ... Ah!, pra mim, sempre foi bom, mas ao mesmo tempo você fica meio, como se diz, sem noção, com medo de pegar nele, de tocar, de quebrar. Eu dei de mamar, não tive dificuldade. PEPITA

... Foi bom! Eu não quis engravidar, aconteceu. ... É bom porque a gente pode cuidar melhor, pode dar mais atenção, porque a gente pode acompanhar o crescimento ... a gente é mais nova, tem mais tempo. ESMERALDA

Eu gostei, eu me senti bem! ... Eu não sabia dar de mamar, dar banho, trocar ... essas coisas, mas aprendi. ... ÁGATA

... Ah! maravilhoso! O primeiro, não foi programado, veio mesmo de surpresa. ... Eu gostei de ser mãe ... cuidei bem dele, dei de mamar, me ensinaram a cuidar dele ... Eu estou achando bom, gosto de cuidar ... agora, tudo bem ... MARCASSITA

... Eu gostei, foi uma experiência boa, ... acho que sou boa mãe ... minha mãe me ensinou um pouco no começo ... mas eu sempre cuidei bem, porque minha irmã teve filho e eu sempre ajudei ela cuidar. ... JADE

Em outros discursos (de todos os pais e de uma mãe), a percepção perpassa pelo estranhamento, pela surpresa, por dificuldade com a experiência e até pelos sentimentos de raiva e solidão:

... O primeiro nascimento foi bem uma experiência. Assim, foi difícil, não tinha tanta responsabilidade. Era um pouco difícil conciliar o trabalho com a escola, com cuidar do filho ... era um pouco difícil, né? O mais difícil foi isso daí. DIAMANTE

O filho não foi planejado, aconteceu. Ser pai pela primeira vez foi, durante a gravidez, como se fosse um sonho, mas depois que a criança nasceu, ficou a responsabilidade ... ÔNIX

... mas depois ele nasceu, Eu fiquei, tipo, sozinha ... me sentia sozinha! Eu não ligava muito pra ele! Não dava aquele amor de mãe! Não gostava dele! Fui gostar dele mesmo quando ele tinha nove meses. Não sabia cuidar de criança, cuidava na marra, né? SAFIRA 
O amor materno ou paterno, como qualquer forma de amor, é algo construído. Sendo assim nem todos os homens ou todas mulheres sentem de imediato o amor que se espera deles. Então, como esperar esse sentimento de indivíduos em formação de uma identidade, ainda sem um completo estabelecimento de valores pessoais, sobretudo, quando a maternidade e ou paternidade não foram planejadas?

... O primeiro eu achei estranho. Assim, depois me acostumei. Mas nós programamos ele, não teve problema nenhum. ... Primeiro, eu achei estranho, depois me acostumei, é bom ... não acho ruim, não ruim. Acho que sou bom pai, é ... eu ajudo a cuidar dele ... trocar , dar banho ... JACINTO

Perscrutando a literatura científica encontrei inúmeros autores que investigaram a gravidez na adolescência e observaram alguns fatores relacionados a ela, dos quais destaco: escassa prática religiosa; fracasso e/ou evasão escolar; repetição da gravidez na adolescência; influência intergeracional; maturidade sexual mais precoce; permissividade familiar; baixa auto-estima, disfunção ou instabilidade familiar; situação econômica desfavorável; escassa expectativas e metas; ociosidade; imaturidade psicoemocional: idéia de onipotência ou egocentrismo (Carvalho, 1998; Carvalho e Barros, 2000; Guimarães, 2001; Carvalho e Merighi, 2004), influência dos meios de comunicação; dificuldades de acesso ao planejamento familiar; dificuldades para lidar com as informações que têm; necessidade de uso clandestino do método; falta de diálogo com o parceiro; preconceito dos pais e ausência de diálogo entre pais e filhos; instabilidade e insegurança próprios da adolescência; bloqueios emocionais (teste de fertilidade, agressão aos pais, sentimentos de culpa em relação à atividade sexual, medo de consulta médica, desejo de ser mãe/pai); baixas aspirações educacionais e poucas realizações pessoais; problemas comportamentais como: atividade sexual precoce, uso de álcool e drogas, entre outros (Clerget, 2004; Vitalle e Amancio, 2006; Brasil, 2006; Vitiello, [s.d.]; Bueno, 2006); pressão do grupo em relação ao início da atividade sexual; maior tolerância social para a atividade sexual (OPS, 1992; e vários outros). 
Entendo que a família representa o principal ponto de referência dos jovens, sobretudo nas camadas sociais mais baixas. Em seu estudo sobre a percepção de familiares a respeito da gravidez adolescente, Silva e Tonete (2006) perceberam que os familiares de gestantes adolescentes mobilizaram-se na formação de uma verdadeira rede de apoio, oferecendo suporte durante toda a gestação e elaborando planos para o cuidado da criança.

O suporte familiar percebido pelas gestantes durante a gestação, segundo Lima et al. (2004) inclui a ajuda financeira, explicações, conselhos, carinho e apoio emocional.

Alio-me a Brandão (2003) quando afirma que o nível de escolarização e dificuldade de inserção no mercado de trabalho aumentam a dependência dos adolescentes em relação aos pais. No entanto, o alongamento da dependência familiar não impede o exercício da autonomia nessa fase da vida, na qual a sexualidade tem grande relevância:

... Eu tenho a ajuda da minha mãe ... meu marido fica do meu lado, então, isso ajuda mais a gente, fica mais segura pra criar ele e tudo. RUBI

Nesta visão, a figura da mãe, sobretudo da mãe das adolescentes, revela-se como a mais importante referência aos jovens na transmissão de conhecimentos à próxima geração. A gravidez e a maternidade precoce da mãe da adolescente prenunciam uma forte influência intergeracional no padrão sexual e reprodutivo dos filhos, sobretudo, no gênero feminino.

Vitalle e Amancio (2006) afirmam que experiências sexuais mais precoces são observadas naqueles adolescentes em cuja família os irmãos mais velhos têm vida sexual ativa, sendo importantes indicadores do ambiente familiar que tipicamente provê papéis alternativos mais limitados e menos opções aos adolescentes.

Este tipo de ambiente promove a repetição do ciclo gravidezparentalidade repetida. Percebo esta influência nos trechos de discursos de 
alguns adolescentes que também tiveram mãe e ou pai que foram pais adolescentes, como serão apresentados, a seguir:

... Eu não posso falar o que é muito cedo, pois a minha irmã mesmo teve o primeiro filho dela aos 14 anos e, pra ela, também foi bom. PEPITA

... minha mãe também casou cedo, com 12 , com 13 teve minha irmã e com 14 eu nasci. ... Pra mim, não tem nada a ver a idade se a pessoa se gosta se assume o filho, não tem diferença. JACINTO

... Meus pais tiveram muitos filhos, cinco, e cedo [a mãe teve o primeiro aos 17 anos]. TOPÁZIO

Segundo a Teoria schutziana, o acervo de conhecimentos disponíveis possibilita ao indivíduo desenvolver atividades teóricas ou práticas e determina elementos relevantes para sua ação. Assim, as vivências pessoais armazenadas definem quais elementos, dentre os contidos em uma determinada situação, são significativos para a formação de seu sistema de relevâncias (Schütz, 1974a).

Para Schütz, as experiências acumuladas auxiliam no projeto de ação relacionado ao presente vivido. Desse modo, as pessoas podem orientar-se no mundo da vida, utilizando estas experiências para criar códigos de interpretação de vivências passadas e presentes (Wagner, 1979).

Dessa maneira, os motivos por que dos adolescentes estão vinculados ao passado, às suas vivências e as de seus predecessores que neles desenvolvem a confiança e a segurança para ter o mesmo comportamento.

Ao estudar sobre a maternidade adolescente, Almeida (2002) encontrou três situações diferentes nas quais ocorreram gravidezes e parentalidade precoces: entre aqueles que se achavam em união consensual; adolescentes com longo tempo de namoro e aqueles com namoros recentes.

As observações da autora são semelhantes ao encontrado no presente estudo: a gravidez precoce ocorre entre casais adolescentes antecipando em função de um projeto para mudar de vida ou legitimar o 
relacionamento junto aos familiares. Entre os adolescentes com longo tempo de namoro, antecipando o projeto de união do casal, sendo justificada por eles pelo descuido decorrente da intimidade adquirida. Em um namoro recente assume o sentido de inesperada e não desejada (pelo menos, a princípio), visto que o curto tempo de convivência parece dificultar a negociação do uso de um método anticoncepcional.

A seguir, os fragmentos dos discursos apresentados ilustram as circunstâncias acima descritas:

... Casei depois de três anos amigados. Aí, veio minha segunda filha ... SAFIRA

... eu estava namorando e eu quis, foi uma experiência boa! RUBI

... já estava tendo um relacionamento [há mais ou menos cinco anos] ... Adorei porque eu já estava planejando, namorava ele desde os 12 anos.

ÁGUA-MARINHA

... Estávamos namorando [começando], aconteceu e, nós, mantivemos a gravidez. PEPITA

... a gravidez foi planejada, eu namorava meu marido e nós ficamos junto aí, aconteceu a gravidez. ÁGATA

... o primeiro, veio mesmo de surpresa. MARCASSITA

... o segundo, também, não foi planejado [foi no primeiro mês de namoro]. ÔNIX

As percepções dos adolescentes no nascimento do segundo filho, constitui o tema da próxima subcategoria.

\section{- Subcategoria: Sendo pail mãe recorrente}

Pensamos de um modo empírico que uma primeira paridade não planejada, na adolescência, poderia ser uma razão suficientemente forte para prevenir sua recorrência, porém isso não encontra respaldo neste estudo, conforme vários sujeitos revelaram que não houve planejamento de nenhuma das gravidezes.

$\mathrm{Na}$ literatura científica, existem registros de que os adolescentes raramente planejam suas gestações (Machado, 2001; Stevens-Simon et al., 2001; Sari, 2002; Aquino et al., 2003; Almeida et al., 2003; Paulics, 2006). 
Quanto à contracepção após o primeiro filho na adolescência, Aquino et al. (2003) encontraram que $37,6 \%$ dos homens e $45,6 \%$ das mulheres passaram a utilizar algum método. Entretanto, 19,7\% e 21,5\%, destes respectivamente, permaneceram em relações desprotegidas e os porcentuais daqueles que engravidaram novamente, corresponderam a um em cada quatro pais ou mães adolescentes.

Meu segundo foi um acidente. Eu estava tomando remédio, eu fiquei um período sem tomar para tomar outro. Aí, eu engravidei da minha filhinha ... Foi um sufoco! ÁGUA-MARINHA

O segundo também não foi planejado mas, desta vez, estou tranqüila ... mas estou aceitando bastante. PEPITA

A primeira relação pode predizer o comportamento sexual posterior. Desse modo, as mulheres que utilizaram algum método anticoncepcional na primeira experiência sexual tendem a adotá-lo nas outras relações, independente de sua situação conjugal, afirma Bozón (1993).

Diversos estudos demonstram que os adolescentes são bastante informados sobre métodos anticoncepcionais, mesmo que estas informações sejam incompletas ou parcialmente corretas. Penso, entretanto, que informações isoladas não bastam para modificar o comportamento sexual e reprodutivo dos adolescentes. Mesmo conhecendo os métodos contraceptivos, vários entrevistados deste estudo não os utilizaram nem planejaram as gravidezes.

Algumas pesquisas apontam uma tendência ao relaxamento das práticas anticoncepcionais pelos adolescentes, conforme os relacionamentos afetivos tornam-se mais estáveis, o que também foi desvelado neste estudo (Benfam / DHS, 1997; Aquino et al., 2003; Almeida et al., 2003, Brandão, 2003).

A freqüência das relações sexuais também influencia a prática anticoncepcional, ou seja, aquelas que têm mais relações, tendem a ser mais precavidas do que as que têm relações esporádicas. 
Para outros autores como Longo (2002) o risco de uma gravidez aumenta para as adolescentes que já pariram alguma vez. E àquelas com relacionamento estável cresce a probabilidade de uma prole grande. As adolescentes que iniciam a atividade sexual com o namorado ou marido têm maior probabilidade de utilizar anticoncepcionais do que as que iniciaram com outro tipo de parceiro.

Dados de outras pesquisas são concordantes com o presente estudo e revelam que os adolescentes, geralmente, não são promíscuos. A maioria dos sujeitos teve sua primeira gravidez, assim como suas primeiras relações sexuais com o primeiro namorado, ou em um contexto amoroso e alguns também tiveram os demais filhos com o(a) mesmo(a) companheiro(a).

Mas surge um fato preocupante, geralmente, o padrão reprodutivo é definido na adolescência. Deste modo, quanto mais jovem for a mãe, maior será a probabilidade de multiparidade, ainda nesse período do ciclo vital (Benfam, 1997).

Os adolescentes deste estudo tinham dois ou três filhos, entretanto, deparei em minha prática docente-assistencial com jovens que apresentaram quatro ou, até mesmo, cinco paridades ainda na adolescência. Em consonância com a literatura, os adolescentes deste estudo revelaram que as gravidezes não foram planejadas. Contudo, vale lembrar que gravidez não planejada nem sempre significa filho não desejado.

Neste sentido, transcrevo, na seqüência, fragmentos de alguns discursos dos sujeitos deste estudo:

... Agora, vamos ver. Acho que vou dar conta das duas. Eu acho que não vai dar problema, pode dar, assim, ciúmes. No começo da gravidez, eu queria tirar. Ai!, eu queria tirarrr! Aí, ele brigou comigo porque eu queria tirar ela. Agora, tá tudo bem! ÁGUA-MARINHA

O segundo, também, não foi planejado, mas está sendo diferente porque eu tenho mais experiência. Está sendo bom! ESMERALDA

Esse [o segundo] aqui não foi planejado. Eu parei de tomar remédio, tava descansando, tava usando camisinha, mas eu queria mesmo mais um, mais cedo ou mais tarde. ÁGATA 
O segundo, também, não foi planejado ... mas foi diferente. Acho que nesse vai ser diferente. ÔNIX

O segundo, também, foi bom ... Não foi assim pra falar, planejada, não! RUBI

... foi um choque, porque no começo eu não queria, não foi programado, o outro tinha seis meses. JADE

Climent et al. (2000) comentam que o aumento da quantidade de filhos entre mães adolescentes é diretamente proporcional à intensidade da exclusão social a que estão submetidas. Os relatos de alguns sujeitos deste estudo confirmam esta circunstância.

Segundo os autores citados, a trajetória de vida das mães adolescentes segue uma rota que conduz a uma grande marginalização conseqüente ao empobrecimento dos projetos e qualidade de vida.

A falta ou o empobrecimento dos projetos (motivos para) refere-se, portanto, à atitude interna desses adolescentes que vivem no processo de sua ação.

No mundo da vida, cada adolescente, como um indivíduo tem uma história, vive em um determinado ambiente físico e sociocultural, trazendo consigo um acúmulo de conhecimentos e experiências decorrentes de seu modo de viver, vislumbrando o mundo por uma perspectiva diferente de seu semelhante, pois tem sua situação biográfica própria que inclui certas possibilidades de atividades teóricas ou práticas futuras de "propósito à mão". Este acúmulo de conhecimentos à mão serve-lhe como um código de interpretação de suas experiências passadas e presentes e também determina sua antecipação das coisas que virão (Wagner, 1979).

Desse modo, para Schütz (1974a), a situação biográfica define o modo pelo qual a pessoa ocupa o cenário da ação, interpreta suas possibilidades e enfrenta seus desafios.

O significado subjetivo de pertencer a um grupo representa a importância que o grupo tem para seus membros, freqüentemente, descrito como um sentimento entre os membros dos quais pertencem ao conjunto ou 
de que compartilham interesses comuns. O significado subjetivo que o grupo tem para seus membros, consiste no conhecimento de uma situação comum e, com ela, de um sistema comum de tipificações e relevâncias (Wagner, 1979; Schütz, 1974a).

Wagner (1979) ainda esclarece que esta descrição vale tanto aos grupos existenciais com os quais compartilho uma herança social, como aos chamados grupos voluntários que eu formo ou aos quais me associo.

Mesmo com as mudanças expressivas nas relações de gênero, o pai adolescente ainda desempenha o papel de provedor da família. Contudo, há sinalização de uma nova dimensão da paternidade, com pais que se envolvem de forma bastante ativa em seu papel paterno, vivenciando um maior envolvimento afetivo com a díade parceira-filho e compartilhando com a parceira alguns cuidados com a criança, trazendo benefícios às crianças, assim como indicam os trechos abaixo discriminados:

... eu ajudo a cuidar dele ... trocar , dar banho ... JACINTO

... eu cuido dele como cuida uma mulher normal, quando a G. tava no hospital, eu que fazia tudo, cuido da casa e tudo ... mesmo quando chora à noite, eu não ligo, não ... igual o primeiro ... ele chorava. Assim, à noite, eu pegava ele, já não acordava ela ... Eu vou cuidar do segundo, como eu cuidei do primeiro. Tem gente que não sabe cuidar de uma casa, fritar um ovo, trocar uma fralda. Aí, já atrapalha tudo ... pra mim, não! Eu sei cuidar de casa ... e, igual eu cuido de um, eu cuido do outro. CRISÓLITO

... você se preocupa com pequenas coisas: o que está fazendo, se vai cair, se vai machucar ... hoje, se eu tiver um tempo disponível, eu vou querer tar com meus filhos. TOPÁZIO

... Os filhos moram comigo. O Ju vai comigo pra loja na parte da manhã... aí um pouquinho, antes do almoço ele vai para casa pra tomar banho, almoçar pra ir pra escola. À tarde, eles vão pra escola. Na hora de sair... quando as crianças deixam a escola, vão para casa da avó. Na hora que saio da loja, pego os dois e levo pra casa, fico com eles até eles dormirem. Praticamente, só não fico com eles à tarde.

DIAMANTE

Unbehaum (2001) lembra que a responsabilidade pelos cuidados dos filhos, ainda se apresenta como uma atividade feminina, entretanto, a estrutura social, mesmo marcada por desigualdades e organizada, segundo a divisão sexual não tem dificultado mudanças. 
Para as mulheres, a realização de tarefas domésticas inicia-se muito cedo, sendo parte do processo de preparação para a maternidade, especialmente, entre as classes sociais mais baixas (Brandão, 2003). preparo da mulher para a maternidade ocorre com as brincadeiras com boneca, de casinha e, às vezes, inclui até mesmo práticas maternais com os irmãos mais novos. Em jovens das classes sociais mais carentes, a maternidade prenuncia mais que um destino, mas, uma fonte de valorização social.

Certamente um dos aspectos mais difíceis e, ao mesmo tempo, mais importantes da paternidade, é o estabelecimento de vínculo afetivo com o filho, baseado na comunicação e na confiança entre pai e filho, sobretudo, o primeiro filho. É diferente das mulheres, para as quais o vínculo com a criança parece ser estabelecido mais precoce, a partir dos primeiros movimentos do feto, a concretude da paternidade, talvez, somente se verifica após o parto. Talvez, seja esta a razão pela qual todos os pais adolescentes usaram expressões como "estranho", "novidade" e "expectativa", percepcionando o nascimento de seus filhos.

Em relação à parentalidade adolescente, notamos uma assimetria entre os gêneros. Ao pensar ter um filho, é freqüente que as mulheres avaliem essa decisão em termos das conseqüências que este evento teria sobre suas vidas. Entretanto, os homens detêm em analisar se estão ou não preparados para responder as necessidades dos filhos (Domínguez, 1998).

Para esta autora, os homens não se projetam no filho de igual modo que as mulheres, para as quais este parece mais uma extensão delas próprias, sendo mais difícil para elas reconhecer-lhe a existência independente da sua própria.

À luz do pensamento schutziano, cada indivíduo posiciona-se, de maneira singular, no mundo da vida, definindo, sua situação biográfica, ou seja, o modo pelo qual ele ocupa o espaço da ação, interpreta suas possibilidades e envolve-se com seus desafios. A sedimentação de suas 
experiências torna-se condição para a interpretação de eventos e ações posteriores. A situação biográfica ou estoque de conhecimentos é a experiência vivenciada anteriormente que armazenada vai determinar os elementos relevantes à ação. Portanto, o significado que o indivíduo atribuir à sua ação estará baseado em sua situação biográfica (Schütz, 1974a).

Compreendi que os adolescentes diante da parentalidade e de sua repetição vão elaborando as mudanças, realizando adaptações que acreditam ser necessárias e a partir do segundo nascimento não houve um grande estranhamento ou surpresa como no primeiro. Na seqüência, destaco fragmentos de seus discursos, tratando da questão de ser pai/mãe adolescente mais de uma vez:

... O segundo já ... quando nasceu, nem o primeiro era tão pequeno. Então, foi mais fácil, já estava uma estrutura melhor de formação ... assim ... uma formação, dividia melhor o trabalho, já não estava estudando mais, já tinha mais tempo pra cuidar, tanto do primeiro como do segundo. Olha, o primeiro é aquilo lá ... uma novidade ... você fica com um monte de expectativa, sei lá! Fica tentando imaginar como é que é, fica bem bobo. O segundo, foi mais natural, já tinha o primeiro, foi mais normal. DIAMANTE

Foi bom, foi programado. Este não achei estranho, não! Tipo, pra seguir a minha mãe, ela teve dois. Vai ser legal os dois. Vai ser melhor pra mim, já tenho experiência com o outro, tô cuidando melhor ... agora também é um menino. JACINTO

... Ah! Eu me assustei um pouco, ele não foi programado, então, no começo fiquei meio assim. Depois você vai acostumando, acostumando e, se tiver uma educação como o outro, vai ser normal ... vai educar a mesma coisa, vai dar a mesma educação do outro. CRISÓLITO

Vários pesquisadores sobre o tema da paternidade referem um envolvimento paterno significativo com a criança, seja com auxílio financeiro ou por meio de outras formas de atenção. Presumimos que estes jovens sejam capazes de transpor obstáculos e tornarem-se pais competentes e cuidadosos (Robison, 1988; Young, 1988; Allen e Doherty, 1996; Cochran, 1997; Marsiglio e Cohan, 1997; Dallas e Chen, 1998; Trindade e Bruns, 1999). 
Em que pese ser a parentalidade adulta uma etapa natural, previsível e esperada, implica modificações familiares, tanto individuais para cada um dos membros como ao casal e no grupo em conjunto (Velásquez, 2006).

Se no casal adulto, este evento assim se sucede, muito mais intensas serão as implicações a casais adolescentes, ou ainda, na maternidade adolescente sem a presença do companheiro. Isto porque a adolescência é uma fase muito singular do ciclo vital, de "construção do ser", construção de uma identidade, formação de valores éticos e pessoais e formação acadêmica, etc.

Estas modificações ocorridas na gestação e no pós-parto, segundo a autora citada, devem ser analisadas de acordo com a forma de organização familiar e o contexto sociocultural no qual se desenrolam. A evolução positiva ou negativa delas depende dos recursos internos da família, sua condição socioeconômica e o apoio de redes comunitárias, institucionais ou familiares.

Sabroza et al. (2006) ressaltam que independente da condição social de origem, o suporte familiar é o principal fator minimizador de repercussões emocionais negativas da gestação na adolescência.

Endossando os últimos autores, destaco que as condições psicossociais dos adolescentes mais jovens e que não se encontram em união consensual tendem a ser piores, assim como a visão menos otimista da maternidade/paternidade.

O desejo de engravidar e a atitude mais otimista ou positiva em relação à gravidez e parentalidade são mais freqüentes nos adolescentes pertencentes aos grupos etários mais velhos e com união consensual ou civil. Em contraste, o desejo de engravidar e ter um filho na adolescência inicial ou precoce poderiam sinalizar imaturidade emocional e comportamento inconseqüente, típicos da adolescência levando ao exercício irresponsável da sexualidade (Sabroza et al., 2006). 
Não podemos menosprezar a condição vicissitudinária que envolve a parentalidade somada às transformações próprias da adolescência, tendo em vista que esses jovens ainda não se encontram suficientemente habilitados para lidar com eles mesmos.

Chamo a atenção para $o$ fato de que a vivência da maternidade/paternidade na adolescência pode trazer desvantagens, dificuldades e perdas sociais que não apenas interfeririam na vida dos adolescentes individualmente, mas, com repercussões no ambiente conjugal, familiar e social.

Assim, passo a apresentar os aspectos negativos, as perdas e desvantagens conseqüentes da procriação na adolescência que serão os elementos da próxima categoria. 


\section{VIVENCIANDO PERDAS}

Ao analisar os discursos dos adolescentes, tomo conhecimento de algumas perdas relacionadas à realidade socioeconômica e cultural dos jovens em face da parentalidade precoce que será apresentada mais adiante.

Entre os estudiosos da temática em questão, é consenso que a maternidade e a paternidade adolescente são experiências difíceis e que demandam muita responsabilidade, mas podem ser desempenhadas satisfatoriamente pelos adolescentes. Entretanto, estes necessitam ajustar seu estilo de vida às suas novas condições parentais ${ }^{4}$.

Nesta perspectiva, Brandão (2003) afirma que os jovens incorporam a maternidade e paternidade ao processo de crescimento pessoal, na "construção de si", favorecidos pelo apoio que recebem de seus pais que Ihes preservam a individualização.

A falta de suporte social e familiar, sobretudo, da mãe da adolescente e do companheiro, ou mesmo, sua presença conflituosa pode ser uma fonte de estresse à mãe adolescente, incrementando as perdas relatadas por eles:

... agora, de outro lado, tem a idade ... que, pela idade, perde toda a adolescência. Ao invés de você sair, ir curtir, viajar ... tem que cuidar dos filhos ... O fato é assim: não é que atrapalha, mas depois que você tem o filho, você tem que se dedicar a ele. Quando que com 15 anos eu poderia tá fazendo minha festa de 15 anos, poderia viajar, várias outras coisas, poderia ter feito minha faculdade ... JASPE

No que se refere aos pais adolescentes, ainda pouco discutidas, suas dificuldades não são poucas. Estes, geralmente, são menos informados que suas companheiras e têm menor participação no processo biológico da gestação. A notícia de que serão pais, poderá comovê-los profundamente, devendo assumir um papel difícil em um momento crítico de seu desenvolvimento. Alguns tentam desempenhar este papel, mas a

\footnotetext{
${ }^{4}$ Parental: adjetivo de dois gêneros, de origem latina parentãlis; relativo a pai ou mãe
} (Houaiss e Vilar, 2001). 
desvalorização a que são submetidos por suas próprias famílias, as dificuldades econômicas e de trabalho, o abandono social e a relação de conflito que estabelece com sua companheira fazem com que poucos possam assumir e concretizar esta responsabilidade. Alguns abandonam a companheira e o filho, com possibilidade de seqüelas psicológicas, que até agora não foram bem estudadas. Por esta complexa problemática, o genitor adolescente também requer atenção da equipe de saúde, o que ainda não ocorre da maneira que deveria.

Nas publicações científicas nacionais, noto certa invisibilidade da paternidade adolescente, assim como da adulta. Segundo Fonseca (2001), há um silêncio envolvendo a paternidade adolescente, revelando uma relação perversa dos adultos para com o jovem, pois ao anular socialmente a paternidade, acaba-se por legitimar a ausência paterna, dificultando para o adolescente pensar, prevenir ou assumir a paternidade real ou virtualmente.

Continuando, o autor cita que o silêncio relacionado a este evento origina-se na percepção que a sociedade possui do filho, como sendo apenas da mãe. Refere também, que ao decidir assumir a paternidade de maneira ativa, o genitor adolescente não recebe apoio necessário das instituições sociais: escolares, militares, jurídicas, de saúde, etc.

... quando nasceu o segundo, eu ainda não trabalhava, o que eu fazia dava pra me manter. Eu estava conseguindo me manter. Eu falei, agora não dá mais, e tal, tenho que começar a trabalhar legal. TOPÁZIO

... Vai ser um pouco mais difícil porque você não tem aquele dinheiro, pá, né? Mas aí, nós dá um jeito. Minha mãe ajuda nós. O segundo vai ser mais fácil, o primeiro a gente já tira de letra ... CRISÓLITO

Fonseca (2001) acredita na existência de preconceitos de idade, gênero e classe social, assim, relata que predomina a representação social da maternidade, como um evento essencial no destino da mulher, e da não paternidade, como destino do homem. Entretanto, felizmente, nem todos adolescentes, adultos ou profissionais envolvidos com a questão, aceitam passivos estas prescrições sociais e lentamente este silêncio vai transformando-se em um sussurro (Medrado e Lyra, 2006). 
Concordo como os autores, Madeira (1998); Trindade e Menandro, (2002); Silva e Tonete (2006), ao afirmarem que a parentalidade exigiu dos jovens a assunção de novas responsabilidades, o que demandou a diminuição de participação em atividades de lazer e recreação, sobretudo, após o segundo filho. Interromper os estudos antes do planejado ou impossibilitar sua continuidade. Endosso, também, que para alguns rapazes, buscar um trabalho, foi uma necessidade conseqüente às funções parentais no período vital (Madeira, 1998; Oliveira, 1999; Machado, 2001).

A seguir, os extratos dos discursos dos sujeitos apresentados ilustram as condições acima mencionadas:

... Hoje, tenho que trabalhar. Não posso ficar com eles [os filhos] porque onde trabalho é longe [em tempo integral]. Então, eu passo minha responsabilidade toda para o pai deles, por algum tempo, né? ... JASPE

... [no primeiro] não sabia cuidar de criança, cuidava na marra, né? SAFIRA

... a pessoa tem que se dedicar muito! ÁGATA

... Ter filho me ajudou a ter mais responsabilidade ... quando você é sozinho, você não vai ligar ... eu faço e não tô nem aí, qualquer coisa tá bom ... não liga pra nada, mas quando tem família, você pensa, tem que trabalhar direitinho, certo, pra dar um futuro melhor pra eles. CRISÓLITO

O nascimento dos filhos, sobretudo, do segundo filho, impediu os adolescentes de um convívio social mais intenso como antes, restringindo-os ao ambiente familiar. Passaram de uma vida social ativa com saídas ['baladas"] noturnas, freqüências a festas e outras atividades de socialização tão necessárias a estes jovens que estão buscando a construção de uma identidade adulta, para uma vida caseira, como passo a apresentar:

... Eu não era de sair, mas agora com os filhos fica difícil, né? JADE

... a liberdade é o pior, não pode sair, não pode fazer quase nada ... ESMERALDA

... não tinha paciência pra nada. Queria saber de sair, ir pra balada, queria sair pra curtir. Só depois que tive a $R$ é que eu virei mãezona mesmo, dona de casa. Não saio de casa pra nada, só cuido deles, trabalho, também, ... é isso! ... trabalho em casa de família ... SAFIRA

... a sua vida muda, você não pode fazer as mesmas coisa que fazia. PEPITA

... Praticamente, só não fico com eles à tarde. DIAMANTE 
Vários pesquisadores referem que o ônus da criação do filho é maior à mulher e após o primeiro filho, fica difícil para ela retomar os estudos, assim, diminuem suas oportunidades de trabalho (Carvalho, 1998; SmithBattle e Leonard, 1998; Carvalho e Barros, 2000; Cabral, 2002; Carvalho e Merighi, 2004; Vitalle e Amancio, 2006). No entanto, aos rapazes, as perdas não são poucas:

.... pra mim, acho que é bom! Eu não gosto de rua ... é minha característica mesmo, não sou muito de sair ... não acho que perdi minha liberdade ... JACINTO

Apesar do adolescente, citado acima, declarar que não teve perdas, na verdade, sua fala reforça as perdas decorrentes da parentalidade precoce, pois declara que não perdeu em razão do fato de ter uma característica mais caseira, não gostar de rua nem de sair.

... o filho não tira a liberdade ... não tira, se você tiver sentimento, faz a coisa certa,
como eu. Não sou de balada, não curto nada, sou sossegado. Fico em casa,
trabalho certinho, chego em casa, descanso ... igual, que uma pessoa que gosta
de balada, sair todo final de semana, aí sim. Porque, assim, se a pessoa estuda,
aí, atrapalha um pouco. Aí ela quer ajudar você, trabalhar e já atrapalha tudo. Ter
o filho, e lá pra uns 20, que a pessoa tá mais experiente ... CRISÓLITO

Nos discursos seguintes, podemos perceber que a parentalidade repercute no desejo de independência e liberdade do adolescente que tem que repartir seu tempo, espaço e dinheiro, etc., com o filho:

... uma coisa de ruim em ser pai muito jovem é que você perde muito, muita oportunidade, escola, trabalho. ... Eu perdi muita coisa, muita coisa que poderia ter feito e, hoje, eu já não posso mais. Perdi toda a minha liberdade. Porque sendo pai, o tempo que poderia ser todo seu, agora você tem que dar pro seu filho ... perde a liberdade. Não, me lembro de ganhar nada! ÔNIX

Ah!, eu perdi, muito, né? Sem dúvida, eu perdi! Na verdade, eu consigo acompanhar tudo [fazendo o que gosta], porque eu continuo tocando [música]. Perdi, né? Apesar de conseguir acompanhar muita coisa, eu perdi. Você fica longe da situação financeira, assim, longe do seu ideal. Tenho vontade, sempre tive vontade de ter um carro, uma moto. Eu terei, com certeza, com o trabalho que estou, só que ainda não tenho, vou ter ainda. Não tive como conseqüência dos filhos, né? Por isso, que eu falo, assim, da idade, porque com uns 25 anos você pode se estruturar melhor, né? Pode dar uma vida melhor. TOPÁZIO

As próximas verbalizações apontam a demanda de atenção que a criação de uma criança exige e denunciam a perda aumentada para a genitora, sobretudo, àquelas jovens de nível socioeconômico mais baixo, cujos entornos são potencialmente perigosos, violentos ou excludentes: 
... Um coisa de ruim de ter filho cedo, é que agora, eu não vou poder continuar estudando. RUBI

... a pessoa tem que se dedicar muito. Abrir mão de tudo, porque se perde a liberdade ... Eu saía bastante, saía, me divertia, não tinha hora pra voltar pra casa. Mas como eu sou muito chegada a casa, não prejudicou esse lado. Outras pessoas já prejudica. Mas eu conheço muita gente que é mãe hoje que deixa filho largado em casa e vai pra balada. Porque não deu pra fazer naquela época, agora, tá descontando. ÁGUA-MARINHA

... Ter filho mais cedo, eu acho que depende da pessoa. Eu não aconselharia uma pessoa a ter. A sua vida muda, você não pode fazer as mesmas coisas que fazia. PEPITA

... É ruim porque a gente é muito nova e não dá pra trabalhar. Tem parar de trabalhar pra cuidar da criança. Aí, que é ruim ... porque perde a liberdade totalmente, mas de tudo! ... o que eu ganhei com o nascimento ... eu ganhei nada ... muito nada. Ser mãe é como eu falei, é difícil ... difícil pra tudo ... eu acho que tem que pensar mais pra ter cedo. Perde tudo! ... Parei de estudar e trabalhar .... ESMERALDA

... Eu quero terminar de estudar ... tive que parar na segunda série, no início da primeira gravidez porque estava tendo enjôo ... ÁGATA

...Tentei voltar a estudar no ano seguinte, mas engravidei e tive que interromper ... você perde a sua juventude. Assim, não dá pra sair, você fica mais com seus filhos, né? ... se eu foss e planejar eu teria com 18/20 anos. MARCASSITA

... mas se fosse um tempo atrás, eu não teria ... perdi bastaaante a liberdade! Eu não era muito de sair mas, agora, com os filhos fica difícil, né? Eu trabalho, trabalho em confecção da minha irmã, trabalhei até oito meses, agora não sei ... agora não sei como vai ser com o segundo ... vou esperar um pouco ... JADE

Reitero que a sociedade tende a considerar a gravidez e a parentalidade adolescente pelo lado negativo. Entretanto, existem casais adolescentes que demonstram um bom desempenho escolar e profissional além dos papéis parentais. Talvez até querendo provar a si mesmo e à sociedade que são capazes de cuidar de si e de seus filhos. Pois, diferente da adultícia, na adolescência, a parentalidade é cercada de cobranças, ressaltando-se a falta de jeito, as falhas, erros e omissões.

Os adolescentes, sujeitos deste estudo, revelam que também tiveram ganhos representados por amadurecimento, responsabilização e satisfação parental, isto será apresentado na categoria seguinte. 


\section{VIVENCIANDO GANHOS}

Em um estudo com 3.900 adolescentes, realizado pelo Programa de Saúde do Adolescente da Secretaria de Estado da Saúde de São Paulo (Prosad, 2004), constatou-se que o bom na maternidade é: ter alguém (33\%), ter responsabilidade (20\%), amadurecer (13\%), ser chamada de mãe (6\%), ter carinho e compreensão da família (6\%) e 16\% declararam que não havia nada de bom em ser mãe.

As benesses da maternidade/paternidade parecem estar associadas à satisfação pessoal de realizar-se como mulher/mãe, homem/pai. Entretanto, a parentalidade adolescente apresenta desvantagens que estão quase sempre associadas à limitação de possibilidades inerentes a essa faixa etária.

Ao analisar as falas dos adolescentes, tomo conhecimento de que para muitos a parentalidade representa, também, lucros. A experiência dos ganhos está relacionada ao amadurecimento, à responsabilidade e à satisfação advindos do exercício parental.

Contrariamente ao que se pensa, existem diversas vivências parentais e, para alguns, a geração e a criação de um filho são experiências repletas de significados positivos (Folle e Geib, 2004; Silva e Tonete, 2006). Isto, também, é o que Santos e Schor (2003) concluíram, destacando que a vivência da maternidade para as adolescentes não é única nem homogênea e para algumas (alguns) adolescentes, ser mãe (pais) pode ser uma experiência gratificante.

... Mas uma coisa de bom é que a gente pega experiência de vida e tudo, amadurece bastante, tem responsabilidade. RUBI

... É bom porque a gente pode cuidar melhor, pode dar mais atenção ... porque a gente pode acompanhar o crescimento ... a gente é mais nova, tem mais tempo ... não trabalha. ESMERALDA

... pra mim, é melhor ter filho porque eu não gosto de ficar sozinho. Pra mim, não tem nada a ver a idade se a pessoa se gosta se assume o filho, não tem 
diferença. Só assim ... de bom, tipo a minha mãe, ela tem trinta e eu 16 ... a gente trabalha junto ... eu ajudo ela ... ter filho cedo é bom por isso. JACINTO

Muitos autores referem que a maternidade, para algumas adolescentes, é uma escolha e, às vezes, para outras, é até uma solução para a vacuidade existencial, para a baixa auto-estima, solidão ou e/ou abandono emocional.

Sob esta ótica, para muitos adolescentes ter um filho é uma maneira de garantir para si algo próprio e o suprimento de uma identidade social à sua subjetividade fragilizada. O jovem ganha uma identidade própria de "mãe ou pai", socialmente reconhecida, passando a ser este um de seus objetivos.

Um estudo realizado com adolescentes argentinos, com idade entre 15 e 19 anos, mostrou que, para um terço desses adolescentes a maternidade é um projeto de vida, pois não tinham perspectivas (Dianni, 2006). Outros autores também corroboram com esta afirmação (Moreira,1997; Almeida, 2002; Beirão et al., 2003; Almeida, 2003; Santos e Schor, 2003; Almeida et al., 2003; Clerget, 2004; Persona, 2004).

Segundo Pinheiro (2006), para algumas adolescentes, a maternidade representa a busca de um novo status social influenciada pelos modelos e valores vigentes em determinado grupo social, consolidando-se como alternativa de construção de um projeto de vida compatível com as expectativas, normas e possibilidades disponíveis. Outros autores compartilham a mesma opinião (SmithBattle e Leonard, 1998; Almeida, 2002; Almeida, 2003; Beirão et al., 2003; Santos e Schor, 2003; Clerget, 2004; Persona, 2004).

A maternidade e paternidade adolescente nem sempre causam ruptura ou abandono dos projetos de vida. Pelo contrário, muitas vezes, a maternidade adolescente é valorizada por representar a possibilidade de mudanças no status social e melhor mobilidade social no futuro das jovens 
(Sciarra e Ponlerotto, 1998; Oliveira, 1999; Santos e Schor, 2003; Pantoja, 2003; Cabral, 2003; Madeira e Tsucheniro, 2003; Silva e Tonete, 2006).

SmithBattle e Leonard (1998), em consonância com um vasto corpo da literatura científica, comentam que não é a parentalidade adolescente por si que resulta em dificuldades às adolescentes e seus filhos, porém, esta é, particularmente, um fardo e é precária àquelas jovens mães com conflitos, em relacionamento coercitivos ou às famílias, cujos entornos são socialmente "tóxicos", cheios de perigo, violência e de extrema pobreza.

Na seqüência, ressalto trechos dos discursos das adolescentes que revelam ganhos por meio de uma atitude positiva em relação à maternagem ${ }^{5}$ :

... Foi uma experiência muito séria, mas estou achando maravilhoso ... estou encantada com eles. TURMALINA

... Olha, de um lado é bom, porque ser mãe é único ... Acho que vai ser melhor mais pra frente porque a nossa diferença de idade é pouca ... mais pra frente vai ser melhor, a gente vai ter um diálogo melhor. ... O diálogo vai ser melhor, a gente vai ter mais afinidade. JASPE

Acho melhor ser mãe mais cedo, que quando eu ficar mais velha, ele já tá criado ... Eu não sabia dar de mamar, dar banho, trocar ... essas coisas, mas aprendi. ÁGATA

Por um lado, é bom que quando você tiver uns 30 anos, eles já vão estar grandes ... quando eu tiver uns 30, o primeiro vai estar com 20 e este vai ter mais ou menos 18 anos. MARCASSITA

No tocante ao gênero masculino, os discursos abaixo revelam que este também apresenta alguns ganhos. $O$ adolescente é impelido a desenvolver a função de provedor. Assim, a assunção da paternidade além de realçar sua masculinidade e virilidade (Marsiglio, 1993) acelera também a

\footnotetext{
${ }^{5}$ Maternagem: técnica psicoterápica, na qual o terapeuta busca estabelecer com o cliente uma relação semelhante à que existiria entre mãe e filho; vocábulo de origem francesa, maternage, registrado pela primeira vez em 1959, sendo a partir de então, utilizado por diversos autores. O dicionário (Houaiss e Vilar, 2001) registra esta forma, mas o melhor vocábulo, por definição, para caracterizar o ato ou efeito de maternar seria maternação.
}

Maternação: ato ou efeito de maternar; conjunto de atos, comportamentos ou funções, cuidados ou responsabilidades relativos a ou que caracteriza a figura materna ou papel familiar, social ou cultural de mãe (Houaiss e Vilar, 2001). 
transição da condição de adolescente à de adulto, mais "maduro e responsável":

Eu acho que, pra mim, foi bom porque eu amadureci mais rápido. Veio uma responsabilidade pra mim. Fiquei mais responsável, tudo que vou fazer, tenho mais consciência por causa dos meus filhos. Acho que a coisa boa pra mim, é que tenho eles e isso ajudou também para mim... para... como vou falar... ficar mais maduro.. amadureci mais rápido do que o normal.

DIAMANTE

... é seu filho ... é bom, porque quando você vai ficando mais velho, o filho vai cuidando mais de você, vai mostrar pra você como é que é ... porque se você tem filho velho, você vai morrer e não vai nem ver o filho crescer. ... Não saber nem como é que é ... CRISÓLITO

... Ser pai muda muita coisa na vida da gente ... a gente amadurece muito. Mudou muito coisa, no meu jeito de ser, coisa que, antigamente eu tinha a cabeça muito dura. Porque eu sei que as coisas mudaram agora ... ÔNIX

Acredito que, na verdade, ter um filho já é um ganho, mas o que você pode tirar de tudo isso é que você pode olhar pra criança com outros olhos. Você se preocupa com pequenas coisas, com o bem-estar das crianças, o que está fazendo, se vai cair, se vai se machucar. Eu amadurei bastante. Uma coisa boa é que quando eles vão crescendo, você pode tar acompanhando, pode tar jogando um futebol. Eu acho que com meu filho mesmo, eu sei que vou jogar um futebol com ele, vai poder acontecer, tranqüilo! Eu vou tar inteirão, ainda. TOPÁZıO

$\mathrm{Na}$ próxima subcategoria, continuo a reflexão sobre os ganhos associados com a parentalidade adolescente, destacando a experiência da responsabilidade e o amadurecimento que envolvem o exercício parental.

\section{- Subcategoria: Sentindo-se responsáveis e amadurecidos}

As falas dos adolescentes convergiram para o fato de ser pai e mãe e sentirem crescer as responsabilidades, sobretudo, depois do segundo nascimento. Os sujeitos expõem claramente que o exercício parental significou amadurecimento e responsabilidade, como nos fragmentos apresentados abaixo:

... Fiquei mais responsável. ... Tenho ... Tudo que vou fazer, tenho mais consciência por causa dos meus filhos ... e isso ajudou também para mim ... ficar mais maduro ... amadureci mais rápido do que o normal. DIAMANTE

... Ter filho me ajudou a ter mais responsabilidade ... quando você é sozinho, você não vai ligar. ... Eu faço e não tô nem aí, qualquer coisa tá bom. ... Não liga pra nada, mas quando tem família, você pensa tem que trabalhar direitinho, certo, pra dar um futuro melhor pra eles. CRISÓLITO

... depois que a criança nasceu, ficou a responsabilidade. Foi legal, mas foi muita responsabilidade, eu cai na real. Depois que o neném nasceu, só depois que ele 
nasceu, que me deu um estalo ... na cabeça. A responsabilidade é em três coisas, financeira, educação, criar, a criação ... Mas, com o segundo vai ser isso, então, vai ser diferente. ... Eu acho melhor esperar um pouco mais, porque eu fui pai pela primeira vez com 15/16 anos e é uma responsabilidade muito grande para bem dizer um adolescente ainda. Então, eu aconselharia que não fosse pai cedo, não! Ser pai muda muita coisa na vida da gente .... gente amadurece muito. Mudou muito coisa, no meu jeito de ser, coisa que, antigamente eu tinha a cabeça muito dura. Porque eu sei que as coisas mudaram agora. ÔNIX

Eu amadureci bastante. Eu vejo, às vezes, tento fazer um comparativo antes dos filhos e pós ... eu mudei muito, muito, muito mesmo! Eu queria só jogar bola, só sair à noite, só dançar, só tocar, só curtir, só zoar, só vícios que eu não tenho, né? ... mas queria sempre estar na noite, assim. Mas hoje, se eu tiver um tempo disponível, eu vou querer tar com meus filhos. TOPÁZIO

Pelas falas desta subcategoria, foi possível apreender que a parentalidade parece inserir os adolescentes no mundo adulto. No que se refere aos rapazes, a responsabilidade pelos seus atos demonstra ser um dos atributos de virilidade, que fazem parte do ideário da masculinidade. No entanto, ressalto que se torna difícil para os jovens assumir a paternidade sem os suportes familiares e sociais.

Para os homens, a paternidade pode representar um marco de passagem à adultícia e reforçador da identidade masculina. Ao passo que a gravidez colabora na construção da identidade masculina e potencializa a virilidade do jovem, a paternidade e sua assunção ajudam a consolidar a imagem do homem responsável, maduro e adulto, destaca Cabral (2002).

As considerações anteriores, remetem-me novamente ao constructo schutziano da situação biográfica. Os pais adolescentes baseados nesse constructo, como atores, apresentam uma maneira particular de se posicionar no cenário da ação, interpretando suas possibilidades, envolvendo-se com os desafios que se apresentam no mundo da vida. Com a sedimentação de suas experiências, adquirem conhecimentos que lhes permitirão interpretar futuros eventos e ações nos quais estiverem envolvidos (Schütz, 1974a).

Na seqüência, apresento fragmentos dos discursos das adolescentes que também retratam esta subcategoria: 
Meu medo, meu medo, é ter outro baque, tipo, se separar de novo. ... O primeiro filho sem ... com o pai distante ... o segundo com o pai distante ... estou disposta a enfrentar o que vim ... TURMALINA

É muita responsabilidade, assim. Olha, de um lado é bom, porque ser mãe é único! JASPE

... só depois que tive a $R$, é que eu virei mãezona mesmo, dona de casa, não saio de casa pra nada, só cuido deles, trabalho também ... é isso! Trabalho em casa de família, levo a $R$ [a terceira criança] pro meu serviço. ... Eu dou conta do meu serviço e dela. SAFIRA

... agora meu pensamento é nele, não vai muito pra mim. É mais pra eles agora. Mas uma coisa de bom é que a gente pega experiência de vida e tudo, amadurece bastante, tem responsabilidade. Pra meu namorado, também ... pra ele vai servir pra amadurecer bastante como pai ... que ele queria o filho. Então, eu acho que ele já estava se preparando pra isso. RUBI

É muita responsabilidade, a pessoa tem que se dedicar muito. Não, eu não quero mais ter filhos por causa das condições financeiras, também, que hoje em dia está mais difícil. ... A violência tá aumentando, os jovens nas drogas. Eu penso assim, será que eu vou conseguir dar jeito [nas filhas] nesta fase de balada? Minha preocupação não é tanto de ter de criar, mas isso ... ÁGUA-MARINHA

Passo agora a discorrer sobre uma subcategoria que expressa a satisfação dos adolescentes com a parentalidade:

\section{- Subcategoria: Expressando satisfação com a parentalidade}

Nas últimas décadas, a maternidade e paternidade adolescente vêm preocupando alguns profissionais de saúde envolvidos com esta clientela. Todavia, certos discursos e práticas ainda estão baseados na idéia de que a gravidez e a parentalidade nesta etapa do ciclo vital constituem-se em eventos fora de época, inoportunos e indesejáveis.

Concordo com Pinto e Silva (1998) quando referem que a gravidez de adolescentes não planejada não implica necessariamente em gravidez indesejada ou em filhos não desejados ou rejeitados. Muitos são rapidamente aceitos ou transformam-se ao longo da gestação em desejados, resultando situações felizes e equilibradas.

Percebo que, algumas vezes, a gravidez/parentalidade na adolescência é tratada como empecilho para os adolescentes cumprirem sua função social. Costumamos inferir que os filhos de adolescentes são 
malcriados, problemáticos e rejeitados (Grossman, 1995; Cunha et al., 1998). Mas, pautado em minha vivência assistencial, depreendo que isto não é necessariamente verdade.

Esta visão preconceituosa da sociedade em relação à procriação adolescente aponta para o conceito de Schütz (1974a) do estoque de conhecimentos adquiridos pela experiência individual e, também, de seus antecessores, influenciando as ações humanas, pois o mundo onde vivemos é coletivamente constituído, é intersubjetivo. Embora recebam esta "herança cultural", alguns adolescentes rompem com essas prescrições sociais.

$\mathrm{Na}$ opinião de Elster e Hendricks (1986), a rede de apoio social inadequada para auxiliar os pais poderia delatar a existência de preconceitos e barreiras sociais pelo fato da paternidade (e, igualmente, a maternidade) ser considerada um evento adulto.

As falas dos adolescentes, sujeitos do presente estudo, desvelam sentimentos, como: emoção, novidade, expectativa, encantamento, susto, surpresa em relação ao nascimento de seus filhos. Muitos consideram a experiência da maternidade/paternidade como boa e referem que aprenderam os cuidados com o filho (dar banho, trocar as roupas, amamentar, alimentar, etc.) sem dificuldades, além de outras funções parentais, como apresento agora:

... é bom ... não acho ruim, não ruim. Acho que sou bom pai, é. ... Eu ajudo a cuidar dele ... trocar , dar banho ... Eu gostei , pra mim, acho que é bom, dentro do que eu quero mesmo. ... Pra mim, é melhor ter filho porque eu não gosto de ficar sozinho. JACINTO

... O fato de ser pai é bom ... é uma satisfação ... Bom pai ... eu não sou. ... Eu acho que tenho que melhorar muita coisa como pai, tenho que melhorar um pouco em tudo. ÔNIX

... só que por outro lado sempre foi o meu sonho, ser pai! ... Em relação a filho, tudo que eu imaginava de negativo, foi o inverso. ... Hoje, eu vejo assim, o quanto eu passei até chegar este momento de me estruturar, ficar com uma cabeça boa ... isso é reflexo deles. TOPÁZIo

Rhein et al. (1997) em estudo sobre a participação de pais adolescentes no cuidado da criança, encontraram 54\% deles envolvidos no 
cuidado do filho. Os autores citados relatam que instabilidade financeira ou confusão a respeito do cuidado da criança foi provavelmente a razão para que se estabelecesse o desinteresse e a falta de envolvimento daqueles que não participaram do cuidado.

Fonseca (2001) citando outro estudo afirma que os homens mais envolvidos nos tarefas de cuidados com as crianças relataram maior satisfação conjugal.

Descubro que várias adolescentes deste estudo encontravam-se em união estável com o pai das crianças, fato que também pode gerar satisfação e uma atitude positiva diante da maternação. Reitero que muitos progenitores precoces adaptam-se bem e realizam bem o exercício parental, sobretudo, quando têm apoio familiar e social de seu/sua parceiro/parceira e dos serviços/profissionais de saúde.

... Foi uma experiência muito séria, mas estou achando maravilhoso! Estou encantada com eles! TURMALINA

... Olha, de um lado é bom, porque ser mãe é único! ... JASPE

... É bom, é bom. ... Ah!, Claro, a gente tem uma certa insegurança, assim, na parte de educar, criar, mas é bom, a gente vai aprendendo. RUBI

... Eu gosto mesmo de criança. É que eu ... eu gosto de cuidar! Tudo que ela [a primeira filha] faz, eu fico besta. É lindo e maravilhoso, eu gosto de ver ela fazendo aquilo, então ... ÁGUA-MARINHA

Resultados concordantes com os deste estudo foram os de Heath e Mckenry (1993) que verificaram entre adolescentes maior satisfação com a paternidade do que no grupo de homens adultos. Entretanto, estes autores não investigaram se esta satisfação poderia estar vinculada ao fato desses pais não assumirem responsabilidades em relação ao cuidado das crianças, tendo assim um visão mais positiva e amena da função paterna.

Os achados do estudo de Almeida et al. (2003) mostraram que embora $63 \%$ das adolescentes tenham afirmado não ter planejado a gestação, $89 \%$ citaram desejar engravidar. Os autores acreditam que o fato 
pode ter contribuído para a alto índice de respostas positivas em relação à sua aceitação em um total de $100 \%$ da amostra estudada.

Nesta linha de pensamento, Abeche (2003) colabora ao concluir que a parentalidade na adolescência não é invariavelmente fruto de falha na contracepção ou na orientação anticoncepcional. O autor menciona que existe um número expressivo de gestações planejadas ou bem recebidas pelo casal, sobretudo, quando se trata do primeiro parceiro da adolescente ou de casais em coabitação.

Apoiado nos depoimentos dos sujeitos, depreendo que nem sempre a experiência parental foi planejada, assim, esta não foi indesejável. Eles relatam uma satisfação com o nascimento dos filhos.

Examinando eventuais diferenças nas expectativas e sentimentos de futuros pais adolescentes e adultos, Levandowski (2002), não encontrou divergências significativas na interação pai-bebê entre esses grupos.

Autores como Amini (1996) e Costa (1998) questionam se as conseqüências negativas associadas à gravidez e parentalidade na adolescência não seriam devidas mais ao contexto social desfavorável no qual estão inseridos alguns adolescentes do que à sua idade.

Analogamente a estes autores, acredito que a idade não seja de modo necessário um fator determinante na paternidade/maternidade. Uma vez mais acredito que muitos adolescentes podem se realizar como pais e desempenhar bem os papéis parentais, em especial, quando recebem apoio familiar, social e dos serviços de saúde.

Ao refletir sobre a questão da idade dos sujeitos, intuio que as dificuldades que os jovens enfrentam estão mais associadas à carência econômica, à precariedade de serviços de apoio e ou da família e aos recursos disponíveis que incrementam as perdas e frustrações no processo 
de maternagem / paternagem ${ }^{6}$, podendo levar a um desempenho parental insatisfatório.

Deduzo que iniciar a vida adulta, gradativamente, sem sobrepor etapas, experienciando no total as diversas fases do ciclo vital poderá gerar grandes e saudáveis frutos para o indivíduo, família e comunidade. Entretanto, é necessário assistir os adolescentes para que eles possam ter um desenvolvimento biopsicossocial promissor frente a um longo futuro que Ihes apresenta.

Por mais precárias que sejam as condições vivenciadas, noto nas falas dos adolescentes um esforço no sentido de reorganizar as suas vidas por meio de projetos, expectativas, desejos e sonhos, constituindo, assim, seus motivos para ou a fim de.

${ }^{6}$ Paternagem: trata-se de um neologismo; poderia ser definido como ato ou efeito de paternar; conjunto de atos, comportamentos ou funções, cuidados ou responsabilidades relativos a ou que caracteriza a figura paterna ou papel familiar, social ou cultural de pai; análogo à maternagem ou maternação, registrada por Houaiss e Vilar (2001). Optou-se por utilizá-lo a exemplo de outros autores referenciados neste trabalho, a saber, Fonseca (2001); Medrado e Lyra (1999) e outros. 


\section{BUSCANDO SEGURANÇA PARA O FUTURO}

Como já foi salientado, Schütz (1974a) estabelece que a ação de um indivíduo origina-se em sua consciência, é voluntária e dirigida ao futuro e em sua estrutura temporal, está intimamente relacionada com seu projeto. Assim, a ação humana ou social é uma conduta dirigida à realização de um determinado fim e esta ação - o motivo para ou a fim de - só pode ser interpretada pela subjetividade do ator, pois só este pode definir seu projeto de ação e seu desempenho social.

Entre as questões norteadoras da entrevista, as expectativas dos sujeitos foram evidenciadas a fim de conhecer seus projetos, objetivos, ações, ou seja, seus motivos para. Ao analisar a descrição das experiências dos sujeitos, procurei captar os motivos por que, objetivando a contextualização de suas ações.

Nesse cenário, a análise compreensiva dos discursos dos adolescentes volta-se a seu comportamento social em relação aos motivos, às intenções que orientam suas ações, assim como às suas significações. Ao analisar os impulsos que estão por trás da ação destes adolescentes, remeto-me à Teoria da motivação de Schütz (1974a). Para o filósofo, as pessoas agem em função de motivações dirigidas ao futuro, a seus motivos para. Às vezes, suas ações estão enraizadas em experiências passadas e na personalidade que desenvolveram durante suas vidas, os seus motivos por que.

Nesta perspectiva, a parentalidade parece prover um rito de passagem da adolescência à adultícia e esperança de um futuro melhor, particularmente, quando outras alternativas são difíceis de ser escolhidas no meio social onde vivemos, pela falta de boa formação educacional, falta de serviços de saúde de qualidade, a escassa ou, até mesmo, inexistência de 
oportunidade de emprego. Eventualmente, isso refletiu na solicitude desses adolescentes por um futuro melhor para os filhos diferente do que tiveram.

De acordo com SmithBattle e Leonard (1998), os adolescentes de níveis socioeconômicos mais baixos, de algum modo, sabem que procrastinar uma gravidez não alterará substancialmente suas vidas, por conseguinte, são como que "desviados" para a maternidade/paternidade que, muitas vezes, não é planejada, porém costuma ser bem-vinda na ocasião do nascimento.

Em concordância com os achados de Domínguez (1998), percebi que alguns dos entrevistados demonstraram dificuldades para projetar-se no tempo, pensar e planejar o futuro, sem levar em conta os aspectos anticoncepcionais, já abordados anteriormente, como nas falas que se seguem:

... Ah! Não sei, acho que ... não quero mais casar, não! ... [ri] ... Mas eu penso em ter outro filho, sim. ... Acho que mais um ... não sei ... JASPE

É interessante ressaltar que a entrevistada acima que já esteve em união consensual e, no momento, refere apenas namorar, ao dizer "não quero mais casar", ri como se estivesse duvidando de sua afirmação. Entretanto, almeja ter seu terceiro filho. Seu ex-companheiro, também, adolescente, tem três filhos, sendo os dois primeiros com ela.

Futuro? Ah! ... voltar a estudar ... voltar a estudar ... mas , meus filhos ... não tenho nenhum projeto ... ESMERALDA

Bem, trabalhar ... trabalho na confecção da minha irmã ... agora não sei ... agora, não sei como vai ser com o segundo [filho] ... JADE

Nestes e em outros fragmentos dos discursos, as preocupações dos adolescentes revelam-se mais imediatistas, relativas à saúde da criança e de seu cuidado, alguns até declaram não ter nenhuma preocupação. As expectativas futuras relacionam-se à saúde, felicidade, ao desejo de cuidar bem do filho, intenção de retomar os estudos e trabalhar. Assim como Godinho et al. (2000), percebo uma visão idealizada do futuro, sobretudo, 
nos mais jovens, sem apresentar alternativas concretas e sem visualizar caminhos promissores na sociedade onde estão inseridos.

As dificuldades para projetar-se no futuro estão claramente associadas às condições objetivas de vida, nas quais estes adolescentes encontram-se imersos. A magnitude dos problemas enfrentados no cotidiano é vinculada à alimentação, moradia, vestuário, sustento da família, etc., em contrapartida com as escassas alternativas para resolvê-los que dificultam a possibilidade de planejar e pensar no futuro, visto que não podem exercer um controle mínimo sobre o que lhes sucede (Domínguez, 1998).

O relato sobre os recursos econômicos necessários para criar um filho, assim como sua educação, além do desejo de uma moradia própria foi uma constante nos discursos dos sujeitos deste estudo, como se pode constatar na subcategoria apresentada, a seguir.

\section{- Subcategoria: Solicitude pelo cuidado e educação dos filhos}

Os trechos dos discursos que serão apresentados nesta subcategoria revelam uma solicitude pela educação /formação acadêmica dos filhos e pelo cuidado dos filhos/diálogo com os filhos.

Em minha prática assistencial, encontro que algumas adolescentes, têm, sobretudo, no início, certa inabilidade no cuidado com o filho, o que, muitas vezes, é evidenciada e reforçada por figuras adultas próximas que, por ansiedade e excesso de preocupação, acabam assumindo a maternagem e/ou paternagem, dificultando o desenvolvimento das competências parentais dos jovens.

Em alguns casos, ocorre, até mesmo, a usurpação dos papéis parentais, dificultando o processo de maternagem/paternagem pelos adolescentes. Como exemplo, destaco a história de Rubi, cujo filho mais velho está sendo criado por sua mãe, na casa dela e de Jaspe, pois nos primeiros meses de vida de seu primeiro filho, os pais de seu namorado sugeriram-Ihe abrir mão da guarda do filho para eles. 
As frações dos discursos seguintes apontam a existência de uma certa apreensão quanto ao cuidado dos filhos, até mesmo, pelos genitores do sexo masculino:

... Ter um futuro bom ... assim, cuidar deles, ... Ah! Eu penso assim ... dar o melhor pra eles, ensinar o que é certo e errado. CRISÓLITO

... Ah!, sim, poder sei lá, dar uma vida melhor pro meus filhos, muitas coisas que eu não tive ... TOPÁZIO

... Eu espero que eles peguem firme com o estudo, se formem, não sei. ... Cada um vai escolher a profissão que vai querer. Eu espero mesmo que todos concluam os estudos, e ... Ah! ... Que fiquem bem! ... Cada um tenham a sua vida bem firmada, bem estruturada, que sigam um caminho certo, sejam pessoas honestas, que trabalhem, não desviem, não desandem para o lado errado ... drogas, roubo, ... essas coisas, assim ... DIAMANTE

... mais pra frente vai ser melhor. A gente vai ter um diálogo melhor. Não assim como eu, eu escondia muita coisa do meu pai, eu não quero que eles escondam as coisas pra mim. Acho que o diálogo vai ser melhor, a gente vai ter mais afinidade. A gente conversa muito! Ai! Eu queria ser uma mãe melhor. Eu queria ficar mais com eles ... JASPE

Ah! O meu sonho é que dou uma coisa melhor pros meus filhos, coisa que eu não tive, um amor de mãe, um amor de pai ... fazer eles estudar. Não perder a juventude como eu perdi ... quero que elas esteja estudando, fazendo uma coisa que elas gosta. SAFIRA

... os estudos deles. Agora, meu pensamento é neles, não vai muito pra mim, é mais pra eles agora. RUBI

... As crianças educadas, na escola, estudando direitinho. PEPITA

... dar um bom estudo pra meus filhos quando eles tiver grande, quando eles crescer ter uma profissão ... ÁGATA

Ai, meus filhos! ... que eles sejam homens de bem, que eu quero dar tudo pra eles. ... Eu quero tentar fazer o máximo que eu puder pra eles ... dá tudo pra eles, o que eu puder dar pra eles ... que não falte nada a eles. MARCASSITA

A habilidade para proporcionar uma interação parental de qualidade parece estar relacionada a características pessoais dos genitores (desenvolvimento cognitivo, personalidade, etc.), sendo também influenciada por diversos fatores ambientais e características próprias da criança (Levandowski e Piccinini, 2004).

No que se refere ao gênero masculino, contemplo um consenso entre alguns autores quando dizem que a assunção da paternidade tende a oferecer benefícios diretos e indiretos à criança. Entre os diretos, estaria 0 
auxílio com a alimentação, vestuário, moradia e outras necessidades materiais, bem como a disponibilidade emocional. Quanto aos indiretos estão representados pelas diferentes formas de apoio para a companheira, sobretudo, o emocional. A qualidade da relação da díade pai/mãe afeta as atitudes e comportamentos maternos, repercutindo no desenvolvimento social e cognitivo da criança (Allen e Doherty, 1996; Cabrera, 2000; Levandowski e Piccinini, 2004).

Reporto-me novamente aos conceitos de Schütz (1974a) quando afirma que o mundo social é constituído por meio da comunicação e da ação intersubjetiva dos sujeitos empenhados nessa interação significativa. O autor estabelece que, na relação de interação face a face, os partícipes voltados um para o outro, compartilham simultaneamente determinada experiência vivida, no mundo da vida, no mesmo espaço e tempo. A esta relação, consciente do outro ser humano como pessoa, o autor denominou relação tu. A relação é definida como unilateral quando apenas um indivíduo voltase à presença do outro e recíproca, quando ambos estão conscientes e voltados um para o outro, configurando, então, a relação nós. Nesta última, há participação de um na vida do outro, abertura recíproca aos atos intencionais do outro, vivenciando os conteúdos subjetivos de significados um do outro.

$\mathrm{Na}$ seqüência, transcrevo algumas falas dos adolescentes que ilustram a relação de interação face a face:

... O pai do primeiro só registrou não ajudou em nada e, eu conheci o pai das outras crianças quando o primeiro tinha um ano e pouco ... ele me ajudou até hoje ... aí, a gente casamos no papel ... SAFIRA

... meu marido fica do meu lado, então, isso ajuda mais a gente, fica mais segura pra criar ele e tudo. RUBI

... eu adorei! ... porque já estava tendo um relacionamento com ele ...

ÁGUA-MARINHA

A busca por trabalho, o desejo de uma moradia própria e a retomada dos estudos são os temas da próxima subcategoria. Esta evidencia também a necessidade que os adolescentes pais e mães têm de apoio nas áreas socioeconômicas e médico-assistenciais. 


\section{- Subcategoria: Busca de trabalho, moradia própria e retomada dos estudos.}

Nos trechos dos discursos de todas as mães e pais: Jacinto, Crisólito, Ônix e Topázio está clara a preocupação deles com a obtenção de um emprego ou trabalho melhor; os que estão empregados, o desejo de uma moradia própria ou independente dos pais ou de outras pessoas, o desejo de retomar os estudos, tendo em vista a provisão de algo melhor para os filhos.

Nas camadas sociais mais baixas, é comum os jovens continuarem a coabitar com os pais e contar com sua ajuda, aproveitando suas experiências para a criação de seus filhos. Aquino et al. (2003) encontraram um porcentual significativo de 36\% dos jovens de ambos os sexos, para os quais a chegada de um filho não os levou a deixar a residência dos pais para a concretização da união conjugal.

Neste sentido, Schütz (1974a) escreve que, é da experiência acumulada e dos conhecimentos adquiridos dos seus antecessores que o indivíduo orienta-se nas situações de vida.

Nesta investigação, descubro que, muitos sujeitos, a exemplo de outros adolescentes que também são genitores, coabitam com um ou ambos os pais.

Tomo conhecimento que os familiares, com freqüência, assumem um papel bastante grande no cuidado da criança, permitindo aos adolescentes lidar de forma adequada com o estresse da parentalidade. Na época da entrevista, vários jovens expuseram o apoio de seus familiares na criação de seus filhos, porém, eles mesmos, prestavam-Ihes os cuidados.

Corroborando com as descrições feitas, Almeida relata que independente das circunstâncias em que ocorreram as gravidezes observase o apoio das famílias de origem. Por mais precárias que sejam as condições de vida, os familiares fazem adaptações à nova situação, 
ajudando a reformar a casa, cedendo algum cômodo para o casal morar ou apoiando a adolescente que teve que assumir a maternidade sozinha (Almeida, 2002).

Penso que a ajuda familiar é essencial aos adolescentes, com a providência da moradia e, até mesmo, na transmissão de conhecimentos. Isto me remete mais uma vez ao conceito schutziano do Acervo de conhecimentos disponíveis, já abordado.

... minha mãe me ensinou um pouco no começo ... cuidando da casa; no momento eu não tou cuidando, tem gente que tá cuidando. Minha mãe paga uma moça para cuida da casa. Eu acho que sou uma boa mãe, minha mãe acha que só ela é a melhor ... só ela que cuida bem dele e, pronto! JADE

... trabalho no departamento de vendas de cilindros hidráulicos [com o pai]. JASPE

Pelo depoimento desta última adolescente, nos primeiros meses do primeiro filho, os avós paternos sugeriram-lhe que abrisse mão da guarda do filho para eles.

... o meu filho mais velho mora com ela [a mãe dela] ... nasceu antes do tempo, com sete meses ... RUBI

Não menos digna de destaque, mesmo que muito ainda seja necessário fazer, é a assistência médico-social como denotam as falas seguintes:

... aí, eu coloquei ele numa creche [municipal] de criança desnutrida. ... Lá eles me ensinaram como era cuidar de criança, porque eu não sabia cuidar. Cheguei num ponto de deixar ele desnutrido mesmo, não conseguia amamentar ele direito. Não tinha paciência pra nada ... SAFIRA

Eu não sabia dar de mamar, dar banho, trocar. ... Essas coisas, mas aprendi. Eu aprendi no hospital onde eu dei à luz pela primeira vez ... no Amparo Maternal [maternidade filantrópica] ... lá é ótimo, eu gostei de lá ... não tenho nada do que reclamar ... é, lá é ótimo ... eu gostei. No Hospital Ipiranga [maternidade federal] também [onde deu à luz ao segundo] foi maravilhoso ... lá todos atende muito bem a gente. ÁGATA

... eu dei à luz no Vila Alpina [rede pública estadual] ... cuidei bem dele, dei de mamar, me ensinaram a cuidar dele. ... Minha mãe me ajudou muito, me deu a maior força ... se não fosse a minha mãe! ... Eu morava com ela. MARCASSITA

Infelizmente, a situação da gravidez e a parentalidade adolescente retratadas nas publicações científicas referenciadas e/ou consultadas 
evidenciam uma inadequação, escassez ou ausência de uma assistência emocional, social, médica e financeira de maneira prática e útil às dezenas de milhares de jovens que, anualmente, se reproduzem:

... minha mãe me ensinou um pouco no começo. ... Mas eu sempre cuidei bem porque minha irmã teve filho e eu sempre ajudei ela cuidar. JADE

Na minha família, graças a Deus! Eu tive uma família de pessoas. ... Deus me deu um segmento [familiar] muito bom. TOPÁZIO

... Eu tenho ... eu tenho um pouco de insegurança. ... Tanto que meu filho mais velho mora com ela [sua mãe], que nasceu antes do tempo, com sete meses. Pra mim ... eu fico um pouco insegura, assim, mas tenho vontade de acertar. Eu tenho ajuda da minha mãe ... RUBI

... no primeiro mês da minha primeira filha, tive ajuda da minha mãe ... porque não sabia cuidar nada! ESMERALDA

... Foi mais difícil pela falta de experiência, mas minha mãe me ajudou no resguardo. ... Pra mim, não prendeu, mas uma consulta médica que a gente tem que ir, que não dá pra levar criança, tem que arranjar alguém pra cuidar ... mas a gente dá um jeito ... eu deixo com minha mãe. ÁGUA-MARINHA

... Lógico, que tem o pai que ajuda, tem a mãe. ... Então, você não fica tão em cima. Pelo menos eu não levei tão a sério, tinha quem ajudava. Então, você fica tranqüilo porque tem a ajuda dos outros ... Tenho a ajuda do meu pai e da minha mãe. ... Meu pai paga o plano de saúde, aluguel, escola. Eu trabalho com ele ... ele me ajuda, não tenho salário fixo. DIAMANTE

Novamente, destaco o papel da mãe, sobretudo, da mãe da adolescente no apoio e na transmissão de conhecimentos e segurança tão necessários ao desempenho das atividades parentais desses jovens.

Cabral (2002) refere-se ao processo de transição para a adultícia em termos de incorporação progressiva de atributos caracterizados por autonomia residencial / conjugal e profissional / financeira. Sendo assim, o nascimento e a assunção de um filho parecem incrementar tal processo.

Conforme esta autora, ao contrário das jovens, ao considerar as trajetórias escolar e profissional dos jovens percebemos uma interrupção da primeira em prol da segunda, mais por questões materiais do que em função da gravidez em si, assim como aparece nos depoimentos dos sujeitos deste estudo. 
Pantoja (2003) concluiu que a maternidade propiciou a reafirmação dos projetos de ascensão social, manifestados pelo esforço desprendido dos jovens e por suas famílias na continuidade dos estudos, para dar um futuro melhor ao filho. A importância dos estudos para o projeto de vida assume lugar de destaque nas falas dos adolescentes deste estudo reforçando uma ambigüidade, posto que muitos interrompem os estudos antes ou durante a gravidez.

Torno patente que os relatos sobre os recursos econômicos necessários para criar um filho foram uma constante nos discursos dos sujeitos deste estudo:

Eu pretendo me formar, terminar o colegial. Não penso numa profissão. ... Ah! ... eu queria mesmo, assim, é ser engenheiro. Arranjar um emprego bom, criar meus filhos ... e mais tarde morar na nossa própria casa. JACINTO

Dar uma casa melhor. Ah! Um emprego melhor, pra mim ... vou terminar os estudos pra ter uma coisa melhor, pra dar uma coisa melhor pra eles ... CRISÓLITO

... Eu pretendo a voltar a estudar, arranjar um emprego ... pensar no futuro dos meus filhos ... ÔNIX

... tenho vontade, sempre tive vontade de ter um carro, uma moto. Eu terei, com certeza, com o trabalho que estou ... Mas, eu queria mesmo é ter uma casa própria. Isto é um sonho que eu estou almejando. Eu vou conseguir, ainda. Eu tou batalhando pra isto, trabalho muito pra isto. O outro lado é o sonho musical ... Ah!, sim, poder sei lá, dar uma vida melhor pro meus filhos, muitas coisas, que eu não tive ... TOPÁZIO

Consoante a assimetria de gênero, as maiores diferenças parecem estar vinculadas ao modo que os pais e as mães adolescentes encaram a paternidade e a maternidade, respectivamente. A preocupação dos homens demonstra ter maior clareza que as mulheres a respeito das implicações materiais de se ter um filho. Isto talvez possa ser explicado pelo fato do papel de provedor econômico da casa ser tradicionalmente do homem, como destaca, Dominguez (1998).

No entanto, na presente investigação, ao serem questionados sobre o futuro, ambos os gêneros demonstraram apreensão pelas questões materiais: 
... O que espero é estudar, eu quero fazer Direito ... pretendo, né? ... Trabalhar futuramente como advogada e cuidar dos meus filhos, só isso! TURMALINA

Eu penso, eu queria como todo mundo uma vida estável, ter uma casa, estar bem financeiramente, ter os meus filhos ao meu lado. ... Quero que mais pra frente tenham um bom estudo, uma faculdade ... mais dinheiro. ... Pretendo fazer um curso ou uma faculdade, mas, no ramo que trabalho ... JASPE

Eu quero uma casa no meu nome, um canto meu, com meus filhos, parar de pagar aluguel, viver em paz com eles! Voltar a estudar ... vou fazer o supletivo, também, para ver se consigo um emprego melhor, também, né? ... Tenho estudo ... SAFIRA

A pessoa tem que estudar mesmo, ver o que quer, depois pensa isto ... Por agora, acho que a única coisa que eu quero mesmo é arrumar minha casa e tudo ... pra eles [os filhos], ter um cantinho deles também, né? ... quando eles crescer, ter um lugarzinho pra eles ... os estudos deles. Agora, meu pensamento é neles, não vai muito pra mim, é mais pra eles agora ... Eu gostaria de voltar a estudar, mas agora vai ficar muito difícil com os dois. Eu queira terminar a escola e tudo ... RUBI

... Eu queria ter estrutura melhor, para dar mais conforto ... uma casa maior, minha casa tem só dois cômodos, aumentar mais ter uma vida boa. ÁGUA-MARINHA

... O meu sonho ... Meu marido trabalhando, que agora ele está desempregado. PEPITA

Futuro? Ah! ... Voltar a estudar ... voltar a estudar! Ai! Eu quero voltar a estudar quando eles tiverem maior. Trabalhar! ... poder ter minha casa ... parar de pagar aluguel. Mas, meus filhos ... não tenho nenhum projeto ... ESMERALDA

Eu quero terminar de estudar ... tive que parar na segunda série, no início da primeira gravidez porque estava tendo enjôo ... depois arrumar um serviço, trabalhar ... pra cuidar deles melhor ... porque é melhor, né? ... a gente tando trabalhando pra cuidar, né? ... dar um bom estudo pra meus filhos quando eles tiver grande, quando eles crescer ter uma profissão ... ÁGATA

Ai, meus filhos ... que eles sejam homens de bem, que eu quero dar tudo pra eles ... eu quero tentar fazer o máximo que eu puder pra eles ... dá tudo pra eles, o que eu puder dar pra eles ... que não falte nada a eles. Eu quero voltar a estudar ... eu queria fazer veterinária ... eu tentei voltar depois do primeiro filho, mas aí, engravidei e tive que parar de novo. MARCASSITA

Assim, idade ideal pra ter filho, não tem ... tem que ter um situação boa, sua casa ... Bem, trabalhar, eu trabalho ... trabalhar os dois ... voltar estudar ... um dia ter uma casa ... é assim, a gente morava na casa do meu sogro ... JADE

Além da solicitude pela criação dos filhos e a busca de trabalho, moradia própria e retomada dos estudos, vemos em alguns discursos, elementos mostrando que os adolescentes desejam ter uma vida conjugal e construir uma família, como distingo na próxima subcategoria. 


\section{- Subcategoria: Desejo de uma vida conjugal e a construção de uma família}

Em trechos do discurso das mães, Turmalina e Ágata e dos pais, Jacinto, Crisólito e Ônix, é possível captar o desejo de uma vida conjugal e construção de uma família. Alguns adolescentes falam do empenho para estabelecer e/ou manter o relacionamento afetivo. Um pai de 17 anos (Ônix) chegou a empregar a expressão "lutar para ficar com a segunda companheira, mãe de seu segundo filho", como no seguinte fragmento de discurso:

Acho essencial o pai ficar junto com o filho, entendeu? ... Só que com a mãe do meu primeiro filho não pude ficar, porque nós não lutamos pra isso. Agora, com esse segundo, eu vou lutar pra ficar junto com ela. Vou ser um pai melhor ... lutar pra isso ... vou lutar pra ficar mais junto com ele. ÔNIX

A interferência da situação conjugal, seja legal ou consensual, é reforçada por Stern (1997) que destaca o cônjuge como a referência mais importante e que exerce maior influência na adolescente e em suas condutas durante a gestação e por extensão, acrescento na criação do(o) filho(os).

Corroborando Cowley e Farley (2001) afirmam que o melhor fator preditivo da atitude das adolescentes em relação à gestação e, ouso, pela aproximação do fenômeno, incluir a maternidade, é a percepção da aceitação desta pelo pai da criança.

Chamo a atenção para o fato de que a união conjugal e/ou assunção da paternidade pode não somente alterar a percepção da gravidez/maternidade pela adolescente, mas a percepção de toda a família (Sabroza et al., 2006), que passa a ter uma visão mais favorável do evento.

Neste sentido, Levandowski e Piccinini (2004) afirmam, citando outros autores, a existência de duas situações, uma positiva e outra negativa, a respeito das conseqüências de gravidez (e parentalidade) na vida conjugal de adolescentes. Se por um lado, a parentalidade uniria o casal, pela decisão de viverem juntos, promovendo o crescimento de ambos e uma 
relação afetiva positiva, também, com benefícios à(s) criança(s). Por outro lado, o nascimento de um filho e a decisão de morar juntos poderia desfazer o estado de enamoramento anterior, levando esses casais a experimentarem mais problemas conjugais e separações.

Apesar da vivência da parentalidade ser diversa, concordo com Pinheiro (2006) ao dizer que, geralmente entre as classes sociais mais favorecidas valoriza-se a formação acadêmica e a profissional, estimulandose o adiamento da maternidade (paternidade) e/ou a constituição de uma família para não comprometer a futura inserção do jovem no mercado de trabalho e sua autonomia financeira.

Parece que os adolescentes destas classes são mais propensos a optar por um abortamento, tendo em vista que a parentalidade poderia alterar suas metas educacionais e carreiras.

A autora refere que entre as classes menos favorecidas e sem maiores aspirações acadêmicas e profissionais, as fontes de gratificação e reconhecimento poderiam estar ligadas ao papel de esposa e mãe (esposo e pai).

Dentre os entrevistados do presente estudo, apenas uma adolescente (fragmento já apresentado anteriormente em outra categoria) mencionou a intenção de abortar, na segunda gestação:

... No começo da gravidez, eu queria tirar. Ail, eu queria tirarrr! Aí, ele brigou comigo porque eu queira tirar. Agora tá tudo bem! ÁGUA-MARINHA

Os entrevistados interromperam os estudos por motivo da primeira ou segunda gestação ou, no caso de alguns jovens, para trabalhar no sustento do casal. Estes jovens também manifestaram o desejo de estar junto, pretendendo oficializar a união:

... Pretendo casar, mas só quando tiver 18 anos [no momento tem 16 anos]. JACINTO

... mas quando tem família, você pensa, tem que trabalhar direitinho, certo, pra dar um futuro melhor pra eles ... ensinar o que é certo e errado. CRISÓLITO 
... eu vou lutar pra ficar junto com ela. Vou ser um pai melhor ... lutar pra isso ... vou lutar pra ficar mais junto com ele ... Causa que, o meu futuro, é o futuro dos meus filhos. Esse está sendo o meu projeto, dar o melhor, ter uma família estruturada. Eu estou botando muita confiança neste meu novo relacionamento. ÔNIX

... E tudo de bom no nosso relacionamento, quero que a gente seja muito feliz. TURMALINA

... Eu quero casar ... a gente já tá vendo tudo, pra casar no civil mesmo. ÁGUA-MARINHA

No estudo de Aquino at al. (2003) ter um filho antes dos 20 anos motivou os jovens à constituição de uma união conjugal em $47,8 \%$ dos homens e $39,9 \%$ das mulheres, sendo a porcentagem de união prévia entre homens de $9,3 \%$ contra $18,3 \%$ das mulheres.

A seguir, apresento a categoria na qual os sujeitos expressam elementos de uma situação ambivalente em relação à parentalidade na faixa etária em que se encontram. 


\section{EXPRESSANDO SITUAÇÃO AMBIVALENTE}

$\mathrm{Na}$ busca da compreensão do fenômeno da parentalidade adolescente repetente encontramos nesta categoria manifestações de ambivalência existencial parental pelos sujeitos adolescentes, diante da simultaneidade de eventos vitais vividos, nesta fase do ciclo vital.

Esta categoria caracteriza a reflexão a respeito do que os adolescentes anelam e a realidade vivida por eles, ou seja, a ambivalência de sentimentos: o desejo de ser pai e/ou mãe em contraste com o fato de não querer ter mais filhos (a maioria dos entrevistados); a opinião de que ser pai/mãe cedo é bom, entretanto, não aconselha ninguém a tê-los tão cedo; a opinião de que ser pai/mãe é bom, torna-os responsáveis e amadurecidos mas, em contrapartida, tira-Ihes a liberdade, a juventude e impede a continuação dos estudos.

... Certo ter filho cedo não é, né? ... mas se vir também tem cuidar igual normal ... o filho não tira a liberdade ... não tira, se você tiver sentimento, faz a coisa certa ... como eu ... Pra mim, não tem nada de ruim de ser pai jovem ... pra algumas pessoas tem , né? ... Pra mim, não! Nem pra ela ... CRISÓLITO

... eu gostei de ser mãe, mas foi um trauma no instante que eu soube que estava grávida ... foi um susto ... a gravidez foi um caos ... ficava pensando, um com dois anos ... e outro menor ainda e eu ainda estou um pouco assustada. ... Foi uma experiência muito séria, mas estou achando maravilhoso ... estou encantada com eles. Eu aconselho as outras meninas para estudar, construir sua vida primeiro, depois, sim, pensar em construir uma família. Agora, eu não dou conselho a ninguém. TURMALINA

O processo gestacional, como a parentalidade envolvem alterações intrapsíquicas, interpessoais, etc. Pautada na percepção de concepção surge a ambivalência afetiva - a oscilação entre desejo e não desejo da gestação, o querer e não-querer a criança. Maldonado (2000) explica que não há uma aceitação total ou rejeição total da gravidez, pois o sentimento oposto jamais estará inteiramente ausente. Este é um fenômeno natural que caracteriza, também, todos os outros relacionamentos interpessoais, pois a 
complexidade das relações humanas permite a coexistência dos mais diversos sentimentos.

De igual modo, a adolescência, por si só, é um momento de conflito, de ambivalência, de sentimentos paradoxais, de crise. É muito mais que uma fase de transformações físicas, portanto, deve ser contemplada como um período existencial de tomada de posição social, familiar, sexual entre 0 grupo. Entretanto, é na condição de ser adolescente, na realidade social vivida por estes jovens que se encontra o grande diferencial entre parentalidade adolescente e adulta:

... Uma coisa de ruim de ter filho cedo é que agora eu não vou poder continuar estudando. Mas uma coisa de bom é que a gente pega experiência de vida e tudo, amadurece bastante, tem responsabilidade. RUBI

... No começo da gravidez, eu queria tirar ... Agora tá tudo bem! ... Eu não tenho nada contra de ser mãe cedo. Muito cedo, 12/13 anos acho que não tem capacidade. Quando eu era mais nova pensava, era insegura, pensava sou muito novinha, eu quero curtir ainda. Depois de estar mais sério o relacionamento, na minha cabeça eu queria ser mãe. ÁGUA-MARINHA

Por um lado, é bom que quando você tiver uns 30 anos, eles já vão estar grandes ... quando eu tiver uns 30, o primeiro vai estar com 20 e este vai ter mais ou menos 18 anos. Por outro lado, você perde a sua juventude. Assim ... mas, em compensação, é só olhar pra carinha deles ... que já basta. Eu acho que ... no começo, eu me arrependi ... MARCASSITA

Em alguns discursos, percebo a importância da presença física e do apoio do pai da criança para a adolescente:

Ah!, tava mais experiente, né? ... Já sabia, não estava tão perdida. A gente tava junto [ela e o pai da criança], já foi mais esperado. Do primeiro foi mais um sopetão. Do segundo, eu não fiquei tão perdida, já sabia como cuidar, tudo. Foi mais fácil. Fui uma mãe melhor. JASPE

A primeira vez, assim, eu não queria a gravidez, o pai dele queria que eu tirasse mas, eu não queria tirar, mas depois ele nasceu. Eu fiquei, tipo, sozinha ... me sentia sozinha! Eu não ligava muito pra ele! Não dava aquele amor de mãe! Não gostava dele! ... o pai do primeiro só registrou, não ajudou em nada! ... SAFIRA

... esse eu já quis ... foi tudo bem ... eu também quis porque o pai, ele também assumiu, registrou. MARCASSITA

Nogueira (2006) afirma que a maternidade torna a mulher mais madura e segura, capaz de encarar suas idealizações e permite-lhe uma síntese entre aquilo que ela deseja e o que pode realizar. Entretanto, é 
necessário que ela encontre espaço para o autoconhecimento e desenvolvimento, pois a maternidade/paternidade pode ser tanto uma nova etapa de crescimento ou de afundamento em antigas mazelas não resolvidas.

O fato de ser pai é bom, é uma satisfação ... uma coisa de ruim em ser pai muito jovem, é que você perde muito, muita oportunidade, escola, trabalho. ... Eu perdi muita coisa muita coisa, que poderia ter feito e, hoj,e eu já não posso mais, perdi toda a minha liberdade. Porque sendo pai, o tempo que poderia ser todo seu, agora você tem que dar pro seu filho ... perde a liberdade. Não me lembro de ganhar nada. ÔNIX

Na verdade, no momento que ouvi isso, que ela estava grávida, eu senti um pouco de raiva. Eu falei, ah! ... Não pode ser!, Eu não tou trabalhando ... Só que por outro lado sempre foi o meu sonho, ser pai! TOPÁZIO

Outra razão para o conflito e ambivalência existencial é que a parentalidade na adolescência contraria os projetos que a sociedade prescreve aos indivíduos: as atividades escolares, a preparação profissional, a aquisição de um trabalho remunerado, o estabelecimento de uma relação amorosa estável, duradoura e, só então, a reprodução dentro dos laços do matrimônio. Quando as situações da vida não ocorrem mais ou menos dentro desta seqüência, podem causar certa dificuldade aos jovens como destaco novamente:

... vai ser um pouco mais difícil porque você não tem aquele dinheiro, mais aí, nós dá um jeito ... certo ter filho cedo não é, né? ... CRISÓLITO

... Depois você quer viver a adolescência que você não viveu, aí, fica tudo bagunçado ... JASPE

... uma coisa de ruim em ser pai jovem é que você perde muito, muita oportunidade, escola, trabalho ... ÔNIX

... tive que parar de estudar. Aí, que é ruim. ESMERALDA

... Assim, idade ideal pra ter filho, não tem ... tem que ter uma situação boa, sua casa ... JADE

Vale enfatizar que mesmo diante de uniões planejadas e gravidezes também planejadas, nesta fase do ciclo vital, os adolescentes deverão enfrentar uma série das transformações biopsicossociais decorrentes da gravidez/paridade e parentalidade versus a condição de ser adolescente. 
Noto que os adolescentes deste estudo têm uma relação cuidadosa com suas crianças. Externam queixas pelas limitações às atividades sociais impostas pela criação dos filhos, entretanto não existem sentimentos de ambivalência em relação aos filhos e, sim, pelas obrigações conseqüentes da parentalidade. Quanto ao desejo de ter filhos, expresso por eles, este também poderia representar um desejo de independência ou uma fuga e não um verdadeiro amadurecimento psicoemocional e sexual.

... Vai ser um pouco mais difícil porque você não tem aquele dinheiro, pá ... né? ... Mas aí, nós dá um jeito. Minha mãe ajuda nós. ... O segundo vai ser mais fácil, o primeiro a gente já tira de letra ... bom ... segundo e último! CRISÓLITO

Mais uma vez a ambivalência é desvelada na difícil situação vivenciada pelos adolescentes ao lidar com os dois novos papéis sociais, simultaneamente, o de ser adolescente e ser pai/mãe.

A progenitura confronta os pais (e mães) adolescentes com a privação da liberdade, devendo assumir as responsabilidades econômicas e psicológicas inerentes às funções parentais, todavia o tamanho dessas responsabilidades põe à prova a personalidade do indivíduo, afirma Nunes (1998).

... A sua vida muda, você não pode fazer as mesmas coisas que fazia. Mas assim, se a pessoa quiser coisa séria, criar uma família, ela tem que ter. Eu não posso falar o que é muito cedo, pois a minha irmã mesmo teve o primeiro filho dela aos 14 anos e, pra ela, também foi bom. PEPITA

$\mathrm{Na}$ investigação com 28 pais adolescentes, Westney et al. (1986) encontraram 21 que declararam que a procriação ocorreu antes do que haviam projetado, ou seja, a partir dos 20 anos. Os resultados mostraram despreparo para a paternidade, falta de prontidão com a mesma que se reflete negativamente na reação inicial dos adolescentes à comunicação da gravidez (geralmente, envolvendo ambivalência, tristeza, choque, surpresa e medo).

Nos trechos abaixo, podemos perceber novamente o conflito desses jovens quanto à melhor época ou idade para a procriação: 
... não tem problema, é lá pra uns 20 , que a pessoa tá mais experiente ... CRISÓLITO

... Agora com 18/19 anos, a pessoa já está um pouco mais madura, já sabe o que quer ... RUBI

... se eu fosse escolher agora, eu teria com uns 18 ... se eu fosse planejar eu teria com 18/20 anos. MARCASSITA

...eu acho que deve esperar até uns 28 anos ... assim, esperava terminar os estudos. ESMERALDA

... 17/18 anos tem menina que já é cabeça ... têm outras que não, né? ÁGUA-MARINHA

Sob esta lente para a análise, outro aspecto na parentalidade que poderia interferir nas práticas parentais é a ambivalência provocada pelo desejo por autonomia, típico dos adolescentes e a nova dependência de seus pais para a criação do(s) filho(s), como destacam Teti e Lamb (1986).

Nesse sentido, Trindade e Bruns (1999) comentam que a paternidade (maternidade) é uma experiência dolorosa que arranca o adolescente de seu cotidiano comumente marcado pela falta de responsabilidade e envolvimento em seus projetos. A gravidez e a parentalidade exigem uma reformulação de seus planos e a ambigüidade envolvendo estas mudanças implica uma falta de engajamento com a paternidade/maternidade, evidenciada na dúvida quanto ao desejo de ser pai/mãe.

Os autores citados relatam que esta ambigüidade, muitas vezes, é reforçada pela mídia, por colegas ou familiares. Destaco, concordando com Dallas e Chen (1998), que as solicitudes pela criação e sustento dos filhos tendem a ser comuns, tanto aos adultos como aos adolescentes; entretanto, aos últimos a situação é intensificada pelo fato de possuírem menos recursos disponíveis:

... É bom! Não que me arrependi, mas, se fosse um tempo atrás, eu não teria ... perdi bastaaante a liberdade! O bom é que eu tenho eles! Assim, idade ideal pra ter filho, não tem ... tem que ter uma situação boa, sua casa ... JADE

Os atores no mundo da vida, em suas subjetividades e intersubjetividades, estão a todo o tempo fazendo escolhas que envolvem conflito que exigem soluções, decisões que, por sua vez, determinam uma 
cisão. Eles precisam fazer escolha de algo em detrimento de outra coisa. Assim, quando escolhemos, demonstramos preferência por uma ou outra coisa. Portanto, nossas escolhas (ações), baseadas nos preceitos de Schütz (1974a) determinam nossas intenções e estão carregadas de significado.

A parentalidade trouxe mudanças inesperadas no mundo vida dos atores adolescentes, tais como: responsabilidade em relação à moradia, emprego, sustento do filho/família, além de provocar ambigüidade de sentimentos a respeito do desejo de ser pai ou mãe.

A ambivalência é uma das características da existência do Homem que só se constitui sob laços de tensão, que unem e afastam. Grande parte dos adolescentes tornou-se genitor e genitora recorrentes em uma época de maiores conflitos e ambivalência humana quando estão formando sua identidade e conquistando um lugar na sociedade. Nesse período vital, existe uma ambivalência de se firmar como mulher/mãe e homem/pai.

Um dos mais difíceis aspectos psicossociais da maternidade na adolescência é a possibilidade / realidade que algumas/alguns jovens estejam planejando suas gravidezes. Por um sentimento geral de vazio, de carência de alguém para amar ou para aumentar a possibilidade das jovens "prenderem" o namorado, ou ainda, para não o perderem (Dianni, 2006; Coley e Chase-Lansdale, 1998; Moreira, 1997).

A maternidade/paternidade, também, poderia ser reflexo do desejo de comprovar sua própria capacidade reprodutiva (Gomes et al., 1998; Dadoorian, 2003) e construir uma identidade ou demonstrar independência frente aos pais (SmithBattle e Leonard, 1998; Dadoorian, 2003; Dias e Gomes, 2003; Pinheiro, 2006).

Ah!, foi bom! Porque eu queria, queria mesmo ... a primeira vez, eu quis! Eu estava namorando, e eu quis. Foi uma experiência boa! RUBI

... O primeiro, eu achei estranho, assim, depois me acostumei. Mas nós programamos ele, não teve problema nenhum. [o segundo] Foi bom, foi programado. Este não achei estranho, não! JACINTO

... Eu gostei, me senti bem! A gravidez foi planejada ... ÁGATA 
... A primeira gravidez foi programada, só que, não assim, pensando como seria realmente ter uma criança ... DIAMANTE

Quanto aos pais adolescentes, estes enfrentam grandes desafios, pois, nesta fase, vital estão superando as contingências próprias da adolescência, como a construção da imagem corporal, construção de identidade adulta, separação das figuras parentais, formação educacional, a profissionalização e ainda precisam enfrentar a crise da paternidade.

Sabemos que a possibilidade de um desempenho profissional adolescente bem remunerado é restrita pela falta de qualificação profissional em razão da pouca idade. Zaher et al. (2001) dizem que, geralmente, as condições de trabalho do adolescente são precárias: trabalham muito, ganham pouco e não estão protegidos pela lei.

Para estes autores, existe um paradoxo entre os projetos profissionais e a realidade pessoal e de mercado de trabalho.

Lucchiari (1988) escreve que escolher um trabalho, uma profissão, é selecionar o modo pelo qual desejamos participar no mundo que vivemos, que é, sem dúvida, uma forma de responsabilizarmos também pelas escolhas dos outros. Refere que todo projeto de vida, por mais pessoal que seja, tem sempre um componente social e universal.

Em minha pratica docente-assistencial, é possível constatar que, muitas vezes, os pais adolescentes aceitam a paternidade, conforme cita o estudo de Kahhale et al. (1997). Mas, esta aceitação, não significa necessariamente que assumirão o sustento do casal ou do filho.

Lembro que Schütz (1972) considera que se pode compreender a ação e sua significação subjetiva pelos motivos da ação. O sujeito define e interpreta o sentido de sua ação em termos de motivos para, referente ao que ele pretende alcançar pela ação e os motivos por que, razões enraízadas em suas experiências passadas, na personalidade que este desenvolveu durante a vida. 
Sendo assim, a parentalidade carrega consigo uma história de desejo, com todos os seus matizes, conscientes ou inconscientes. Nos depoimentos dos entrevistados, posso captar diversos sentimentos abrigados nesse desejo, entre estes, destaco a perspectiva de tornarem-se adultos com a paternidade/maternidade e a organização de recursos para um sentido positivo de vida.

Para Sarmento (2001), na adolescência o desejo de ter um filho traz fortes componentes ligados aos sentimentos ambivalentes frente ao processo de tornar-se independente dos pais. Mais uma vez afirmo, agora baseado nas palavras desta autora que, entre as pessoas mais adultas esse tipo de ambivalência também existe, porém, na adolescência, tais sentimentos são intensos e bem marcados pelas transformações próprias do período.

De forma semelhante a autora citada, também acredito que o exercício parental adolescente, não é muito diferente do adulto, pois revestese de medos, anseios, dúvidas e muitas expectativas. Os sentimentos de perdas, mudanças, separação, surpresa, de susto vão se mesclando com outros sentimentos de ganhos, amadurecimento, responsabilidade, independência e satisfação, emergindo, assim, o desejo de cuidar, proteger, amar e participar no desenvolvimento do filho.

As falas transcritas evidenciam que os sujeitos deste estudo vivenciaram situações conflituosas no processo de maternagem/paternagem; e no relacionamento afetivo estão tentando elaborar suas perdas e ganhos, enquanto são compelidos pelas contingências da parentalidade em sua faixa etária, a "assumir" responsabilidades mais precoces. Entretanto, estavam conseguindo, na maioria dos casos, manter o vínculo afetivo com os filhos e com o(a) companheiro(a) e desempenhar satisfatoriamente os papéis paternos. 


\section{CONSIDERAÇÕES GERAIS}

Não se trata de descobrir e percorrer sozinho, uma única vez, uma pista. Mas, de traçar e de concluir, para uso de muitos, uma larga pista. Lebret

Ao percorrer o caminho aberto e já trilhado por predecessores no método fenomenológico, fui em busca de mais um aspecto da parentalidade adolescente, agora, na perspectiva de sua recorrência e dos sujeitos que vivenciam a situação.

Ciente da existência de uma intrincada rede que envolve crenças, valores, tabus e preconceitos relativos às questões de sexualidade, gravidez e parentalidade adolescente, procurei nos sujeitos envolvidos o significado de vivenciar este fenômeno. Neste estudo, busquei dar voz aos adolescentes a fim de compreender o significado dessa experiência para eles e a relação com seus projetos de vida.

Ao optar pela Fenomenologia como estratégia para compreender o significado e as vivências da parentalidade recorrente na adolescência, aproximei-me do referencial da Fenomenologia Social de Alfred Schütz que permite captar a realidade social dos indivíduos por ser um caminho sistemático na compreensão dos aspectos sociais do fenômeno em questão.

Compreendo que as múltiplas vivências da parentalidade adolescente são dependentes do contexto social que, por sua vez, definem os desejos, possibilidades e significações deste fenômeno nas distintas classes sociais.

Nesse período vital, os padrões homogêneos da progenitura descritos em muita literatura científica não encontram respaldo nas falas dos sujeitos do presente estudo.

Percebi que a vivência da gravidez e a parentalidade na adolescência não divergem muito da vivência na adultícia. As maiores diferenças estão 
nas singularidades dessa faixa etária e na realidade social vivida pelos adolescentes. Pais e mães adolescentes enfrentam uma tarefa dupla: tornarem-se adultos, superando as contingências da adolescência: construção de uma identidade, construção da imagem corporal, superação das figuras parentais e profissionalização e, ainda, educar seus filhos. Conseqüentemente, podemos dizer que a gravidez/parentalidade, sobretudo, a parentalidade recorrente na adolescência é duplamente crítica. É, então, uma crise que se sobrepõe à própria crise do adolescer.

Desse modo, as implicações da parentalidade recorrente para o adolescente são inúmeras e, obviamente, o apoio familiar, psicológico e social constituem-se em fatores protetores.

Neste sentido, a intensidade das conseqüências, das perdas e desvantangens serão piores, proporcionalmente à imaturidade emocional dos pais/mães adolescentes, da falta do apoio familiar e social e de recursos financeiros para criação dos filhos.

Em alguns relatos deste estudo, os adolescentes consideram outros fatores, além do econômico que contribuem para que o homem esteja preparado para ter filhos, tenha certa maturidade que não é adquirida necessariamente pela idade, para atender as carências do filho. É preciso acumular conhecimentos a respeito do mundo da vida para transmitir a seus sucessores e ter um(a) companheiro(a) estável para que conte com o apoio afetivo que a criança necessita em seu desenvolvimento.

As representações que os homens têm da paternidade hoje, afastamse um pouco do modelo tradicional, pois exercem um papel mais ativo, próximo dos construídos pela mãe e exibem uma figura tradicional paterna transformando-se.

A realidade de ser pai/mãe adolescente recorrente não é um evento incomum nem uma singularidade de jovens carentes. Entre os entrevistados, havia também adolescentes de classe média, creio, então, que posso inferir 
que se trata de um fenômeno que perpassa pelas várias camadas sociais, porém repercute mais intensamente nas menos favorecidas.

Pela percepção dos adolescentes, notei que eles fazem uma associação de ser pai/mãe, com sentimentos bons, de grande emoção, sonho, susto, surpresa, expectativa, estranheza, novidade e experiência de novas formas de afetividade e preocupação com as mudanças que podem acontecer. Há uma coexistência de diversos sentimentos.

A insegurança no cuidado do filho, sentimento que, muitas vezes, é reforçado por outras pessoas próximas, que, às vezes, assumem a maternagem/paternagem. Aqueles que têm uma experiência prévia cuidando de irmãos menores ou de outras crianças, bastante comum nas classes sociais baixas, parece que se adaptam com facilidades às suas práticas parentais.

Mesmo considerando o aumento da responsabilidade, em alguns aspectos avaliados como positivos e a perda da liberdade, a maioria dos pais adolescentes revelou satisfação com a condição de pai e demonstrou apego afetivo aos filhos.

Julgo que a precariedade de serviços médico-sociais de apoio existentes e dos recursos financeiros que estes jovens dispõem, assim como o ônus do cuidado, da provisão e outras demandas dos filhos que recaem sobre os adolescentes, podem ter resultado com certa frustração e desencanto com a parentalidade, levando-os a aconselhar o adiamento da progenitura.

A assistência aos adolescentes deve considerar não só os aspectos teóricos e cronobiológicos, mas, os fatores psicossociais e culturais que estão envolvidos na parentalidade desse grupo social. Deve-se, também, compreender a vivência desses jovens, pois só os que experienciam a ação, poderão atribuir o sentido que esta Ihes significa. Importa, então, incorporar à prática assistencial a visão de quem é assistido. 
Entendo que a família configura-se como principal ponto de referência dos jovens, sobretudo, nas comunidades de mais baixa renda. Ressalto a figura da mãe da adolescente como mais importante na transmissão de conhecimentos para criação dos filhos.

A maioria das garotas deste estudo encontrava-se em união estável com o pai das crianças, fato que também pode gerar satisfação e uma atitude positiva frente à maternação. Muitos progenitores precoces adaptamse e realizam bem o exercício parental, especialmente, quando têm apoio familiar e social de seu/sua parceiro/parceira e dos serviços/profissionais de saúde.

Nos discursos, foi possível apreender que a parentalidade parece inserir os adolescentes no mundo adulto. No que se refere aos rapazes, a responsabilidade pelos seus atos parece ser um dos atributos da virilidade, fazendo parte do ideário da masculinidade. No entanto, ressalto que se torna difícil a assunção da paternidade pelos jovens sem o suporte familiar e social.

Nesta perspectiva, a parentalidade parece prover um rito de passagem da adolescência à adultícia e a esperança de um futuro melhor, particularmente, quando outras alternativas são difíceis de ser escolhidas no meio social onde se vive, pela falta de boa formação educacional, falta de serviços de saúde de qualidade, a escassa ou, até mesmo, inexistência de oportunidade de emprego. Eventualmente, isso refletiu na solicitude desses adolescentes por um futuro melhor para os filhos, diferente do que eles tiveram.

Os adolescentes de níveis socioeconômicos mais baixos, de algum modo, sabem que procrastinar uma gravidez não alterará substancialmente suas vidas, então, eles são como que "direcionados" para a parentalidade que, muitas vezes, não é planejada, porém bem-vinda na ocasião do nascimento. 
Na busca da compreensão do fenômeno, percebi que a parentalidade recorrente entre os adolescentes requer uma análise de vários fatores e em vários níveis de profundidade, dos mais diversos profissionais. A fase mais elementar dessa compreensão reside nas transformações sociais das últimas décadas e dos fatores psicossocioculturais considerados como associados ao mesmo.

Frente à precariedade de perspectiva de seu meio socioeconômico e cultural, a adolescente pode vislumbrar a maternidade como uma possibilidade de alcançar um status social mais representativo ou o preenchimento da vacuidade existencial. Ela pode estar buscando na maternidade autoridade e poder inerentes à mesma para compensar a imagem da adolescente imatura e dependente por meio do papel maternal socialmente valorizado.

Para os homens, a paternidade pode representar um marco de passagem à adultícia e reforçador da identidade masculina. A gravidez pode, então, colaborar na construção da identidade e potencializar a virilidade do jovem, enquanto a parentalidade auxilia na consolidação da imagem de homem responsável, maduro e adulto.

Por mais precárias que sejam as condições vivenciadas, noto nas falas dos adolescentes um esforço no sentido de reorganizar suas vidas por meio de projetos, expectativas, desejos e sonhos, constituindo, assim, seus motivos para.

A parentalidade adolescente e sua recorrência têm implicações muito além do que a saúde da díade mãe-filho pode dar origem a problemas de natureza psicológicas, socioeconômicas e demográficas com suas repercussões sobre a jovem mãe, do filho, pai jovem, famílias do casal adolescente e em toda a sociedade. Portanto, ter um filho precocemente pode traduzir-se por repercussões físicas, psicológicas e sociais, sendo os dois últimos os mais importantes. 
Ao término deste estudo, foi possível compreender a parentalidade adolescente recorrente. No entanto, ainda vejo a necessidade do desenvolvimento de outras investigações, sob os mais diversos olhares, advindos dos vários campos do conhecimento a fim de desvelar outras perspectivas não vislumbradas nesta pesquisa.

Sustento que os adolescentes progenitores constituem-se em grupos sociais mais heterogêneos do que têm sido descrito previamente. Assim, a freqüência com que os adolescentes procriam, provoca uma naturalização desse evento, como também sua repetição.

No vasto corpo da produção científica consultada, resgatei que as ações de conceber e criar filhos apresentam-se como experiências atribuídas culturalmente, quase de modo exclusivo ao gênero feminino, ignorando-se a participação, os desejos e sentimentos dos homens nesses processos. Quando incluídos nos estudos, seu envolvimento é abordado sob a ótica feminina, reforçando a idéia de que a procriação e cuidado dos filhos são circunstâncias inerentes a este gênero. Quanto ao pai, após um coito fecundante, encara uma grande lacuna em seu papel.

Sendo assim, evidenciamos a necessidade de construção de um lugar social para a paternidade, sobretudo, da paternidade adolescente, que segundo Fonseca (2001) incluiria apoiar os jovens para assumirem de maneira responsável sua capacidade reprodutiva, estimulando-os em todo o processo da gravidez aos cuidados com o filho, ajudando-os a construir seus espaços dentro da família, além daqueles de provedor. Sensibilizar as adolescentes quanto a desejabilidade e necessidade do envolvimento dos pais de seus filhos em todas as fases do processo. Reforçar para os profissionais a necessidade de compreender e apoiar os pais adolescentes favorecendo o exercício parental, além de produzir e divulgar conhecimentos sobre o tema. 
É preciso lembrar que a gravidez adolescente não é um evento exclusivamente feminino e, certamente, não haverá nenhuma resolução se não dermos maior atenção ao gênero masculino.

A partir das últimas duas décadas com o despontar da paternidade adolescente nas produções científicas, começa-se a vislumbrar novas perspectivas da maternação possibilitando, ainda que, timidamente, o compartilhamento da responsabilidade sexual e reprodutiva antes centrada apenas no gênero feminino.

A compreensão da multifatoriedade desse fenômeno e de sua difícil solução deve continuar nos estimulando na busca de soluções, assim, então, poderemos fazer progressos.

Entretanto, percebo que o despreparo dos enfermeiros decorrente do modelo educacional não propicia o olhar holístico que o processo de adolescer exige.

Desse modo, parece-me essencial que exista um novo modelo de formação, não apenas centrado na técnica e no biológico, porém, com uma visão humanística que vá além do atendimento clínico para que possa alcançar o jovem em seu meio, nas escolas e nos grupos.

Ao descrever esse panorama, destaco a visão abrangente do fenômeno e o modo de ser do adolescente (suas perspectivas) nos programas de formação, treinamento e atualização dos profissionais. Eventualmente, uma especialização Lato sensu, na área de Hebiatria, momentos para questionar o conhecimento adquirido.

O Ministério da Saúde refere que

o adolescente e o jovem são definidos por muitos como um símbolo de rebeldia. Porém, não podemos esquecer de sua capacidade de criar e inovar, de suas idéias e pensamentos e, principalmente, da vontade que eles têm de querer mudar o mundo com justiça. É preciso ter uma atenção especial com essa juventude para que administrem sua energia e saúde com sabedoria. Contando com quase 50 milhões de jovens nesta faixa etária, o Brasil não pode ignorar a energia , o espírito criativo, inovador e construtivo dos jovens, 
tampouco seu potencial de contribuição para o desenvolvimento do país (Brasil, 2006).

Nesta linha de pensamento, considero que promover uma assistência humanística aos adolescentes para ajudar seu desenvolvimento de maneira saudável, plena de realizações será o melhor investimento que uma sociedade fará para seu próprio futuro.

Observo que o encontro com a Fenomenologia Social possibilitou a ampliação, o enraizamento do horizonte do significado, além de abrir novas perspectivas e aperfeiçoar um maior conhecimento sobre o fenômeno estudado, pois a arte de fazer a Enfermagem implica encontro muito especial de pessoas, em uma experiência intersubjetiva.

Neste sentido, a Fenomenologia incorpora-se à Enfermagem, pois é uma ciência voltada e realizada para o Ser humano, suas ações devem adequar-se às necessidades de sua clientela. Para isso, é preciso que esta clientela seja conhecida, atraída, ouvida atentamente, compreendida, sendo respeitadas sua subjetividade e a complexidade humana, pelo reconhecimento das diferenças individuais e por não impor fórmulas, modelos e conceitos prontos em seu "Fazer" cotidiano.

A Enfermagem é a ciência da saúde e não da doença, do cuidado, mas, não do paternalismo, da integralidade e não do fragmento. Considera o Ser Humano holisticamente e como sujeito de ação e, assim sendo, deve respeitar sua subjetividade para, então, poder atendê-lo em suas necessidades.

Acredito que o enfermeiro tenha uma situação destacada na assistência apropriada aos adolescentes nos aspectos sexuais e reprodutivos. Entretanto, é preciso que esse profissional encontre significado em suas ações assistenciais e educativas. Assim, em uma relação face a face, de intersubjetividade, baseada no cliente, que respeite sua subjetividade e singularidade possa desenvolver uma relação intersubjetiva compartilhada. 
Ao concluir esta investigação, posso afirmar que a paternalidade adolescente configura-se como um fenômeno complexo, multifatorial, perspectival, inesgotável situado na interface entre desejos, possibilidades e significações que se coloca como um campo indefinido de possibilidades perceptivas.

Os adolescentes não são como se costuma falar jocosamente "aborrecentes" nem "anjolecentes", estão, certamente, buscando e precisam encontrar suas identidades. Eles querem ser adultos, fortes, independentes, querem se auto-afirmar. Portanto, deve-se criar um ambiente favorável para esses jovens crescerem e amadurecerem. Entendo que, ajudar os adolescentes neste processo de construção de uma identidade será apontarIhes um caminho para que conquistem autonomia e desempenhem bem o papel que desejarem, o que poderá até incluir o de pai/mãe e ou pai/mãe mais de uma vez.

A literatura científica sugere que intervenções baseadas nas demandas envolvidas na parentalidade, que aumentem as experiências perspectivas dos jovens, poderão ser mais efetivas que os programas tradicionais de prevenção da gravidez precoce consistindo apenas na transmissão de informações.

Apóio, então, a importância de ações educativas baseadas na relação face a face, com respeito mútuo entre os clientes e os profissionais de saúde por meio de palestras e oficinas abordando o cuidado pré-natal, o preparo para o exercício da maternidade/paternidade, a puericultura e o planejamento familiar, usando técnicas de atividades práticas (hands-on techniques), representação de papéis (role-play) que são essenciais, tanto à prevenção da gravidez indesejada como para encorajar a boa vivência da parentalidade.

Constato o crescimento do número de serviços de saúde destinados a adolescentes, mas vejo ser preciso mais espaço para o adolescente nesses serviços de saúde. Devemos ouvir os adolescentes, conhecer suas 
necessidades e não thes impor modelos prontos, tidos como acabados e melhores. Sustento a existência de uma lacuna entre o fazer dos profissionais e as reais necessidades dos adolescentes, em um despreparo dos profissionais dos serviços de saúde para o trabalho com o adolescente, para atenção às peculiaridades e complexidades de suas necessidades. Acredito na carência de espaços e suporte apropriados às suas demandas, seja no campo da orientação, proteção ou recuperação de sua saúde.

As causas da gravidez e parentalidade precoces são multifatoriais e nos falam da necessidade de investimento no Ser humano, em particular, na educação. Os adolescentes serão mais responsáveis sobre seus comportamentos sexuais e contraceptivos, se eles forem melhor preparados emocional, cognitiva e comportamentalmente para enfrentar as emoções e situações reais que vivenciam.

Enfatizo a necessidade da perspectiva interdisciplinar ao abordar o tema pela complexidade e multiplicidade de implicações que o envolvem, não podem ser restritas a uma discussão apenas ao campo biomédico. Neste sentido, minha vivência e visão de mundo como docente e uma nova reflexão sobre o fenômeno estudado, fortalecerão o elo ensino-pesquisaextensão que caracteriza metas primordiais da vida acadêmica.

Desta pesquisa, emergiu um caminho para um novo modo de cuidar e ensinar o cuidar de adolescentes pais e mães, em uma dimensão humana/existencial e da compreensão de não é mais possível desconsiderar as experiências vividas pelo outro.

A assistência ao adolescente representa uma grande oportunidade para a atuação e valorização do profissional de Enfermagem, entretanto, requer o conhecimento das peculiaridades próprias dessa população.

A inter-relação dos sistemas biológicos (idade, fase do desenvolvimento corporal e cognitivo), psicossociais e culturais deve ser visualizada, pois percebemos como o resultado da formação positivista e 
tecnicista dos enfermeiros, muitas vezes, atenta apenas a um ou dois desses sistemas. Por conseguinte, se todas as dimensões do Ser humano não forem consideradas, em seu sentido mais amplo, o cuidado tornar-se-á dissociado da prática do enfermeiro. 


\section{REFERÊNCIAS}

Abeche AM. Gestante adolescente e seu parceiro: características do relacionamento do casal e aceitação da gravidez. [dissertação]. Porto Alegre: Faculdade de Medicina da Universidade Federal do Rio Grande do Sul; 2003.

Abrahamse AF, Morrison PA, Waite LJ. Beyond stereotypes: who becomes a single mother? Santa Monica: The Rand Corporation; 1988. p. 12-7.

Allen WD, Doherty WJ. The responsabilities of fatherhood as perceived by African American teenage fathers. Fam Soc 1996;77(3):142-55.

Almeida AM, Trindade RFC, Gomes FA, Nilsen L. Maternidade na adolescência: um desafio a ser enfrentado. Rev Bras Enferm. 2003;56(5):519-22.

Almeida MAS. Gravidez adolescente: a diversidade das situações. Rev Bras Est População. 2002;19(2):197-207.

Almeida MCC, Aquino EML, Gaffikin L, Magnani RJ. Uso de contracepção por adolescentes de escolas públicas na Bahia. Rev Saúde Pública. 2003; 37:(5):566-75.

Amini SB, Catalano PM, Dierker LJ. Births to teenagers: trends and obstetric outcomes. Obstet Gynecol. 1996; 87(5Pt1):668-74.

Amparo AMD, Alves PB, Cárdenos CJ. Pertencimento e identidade em adolescentes de risco em Brasília. Rev. Bras Cresc Desenv Hum. 2004; 14(1):1-13.

Aquino EML, Heilborn ML, Knauth D, Bozon M, Almeida MC, Araújo J, et al. Adolescência e reprodução no Brasil:a heterogeneidade dos perfis sociais. Cad Saúde Pública. 2003; 19 Supl. 2:5377-88.

Arenson JD. Strengths and self-perceptions of parenting in adolescents mothers. J Pediatr Nurs. 1994;9(4):251-5.

Atkin LC, Alatorre-Rico J. Pregnant again? psychosocial predictory of short interval repeat pregnancy among adolescent mothers in Mexico City. $\mathrm{J}$ Adolesc Health. 1992;13:(8):700-6. 
Barbosa LMS, Abranches ADG, Peixoto RML, Chaves MAM, Lopes GP, Nascimento LG. Práticas sexuais na adolescência. Rev Soc Bras Obstet Ginecol Infância Adolesc. 1997;1(3):6-11.

Beirão MMV, Mucci AE, Ferreira RA, Miranda SM, Amaral TM. Adolescência. In: Alves CRL, Viana MRA. Saúde da família: cuidando de crianças e adolescentes. Belo Horizonte: COOPMED; 2003. Cap.11, p. 109-33.

Bello MAV, Pinto e Silva JL. Conhecimento, atitude e prática sobre métodos anticoncepcionais entre adolescentes gestantes. Rev Saúde Pública. 2004; 38:(4):479-87.

Berquó E, coordenadora. Comportamento sexual da população brasileira e percepções do HIVIAIDS. Brasília: Ministério da Saúde/CEBRAP;2000 (Série avaliação $n^{\circ} 4$ ).

Bocardi MIB. Gravidez na adolescência: o parto enquanto espaço do medo. São Paulo: Arte \& Ciência; 2003.

Bogaski NT, Schirmer J, Barbieri M. A prevenção das DST/AIDS entre adolescentes. Acta Paul Enferm. 2000;13(1):18-26.

Bozón M. L'entrée dans la sexualité adult: le premier rapport et ses suites. Du calendier aux attitudes. Population 1993; (5);1317-52.

Brandão ER. Individualização e vínculo familiar em camadas médias: um olhar através da gravidez na adolescência [tese]. Rio de Janeiro: Universidade do Estado do Rio de Janeiro; 2003.

Brasil. Ministério da Saúde. Gravidez na adolescência. [online]. Brasília; 2006. Disponível em: <http://portal.saude.gov.br/saude/visualizar_texto.cfm? idtxt $=>$ [Acesso em 16 abr. 2006].

Brasil. Ministério da Saúde. Divisão Nacional de Saúde Materno Infantil. Prosad- Programa de Saúde do Adolescente: bases programáticas. $21^{\mathrm{a}} \mathrm{ed}$. Brasília (DF); 1996.

Bruns MAT. Reflexões acerca do "fazer" metodológico. In: Castro DSP, Ázar FP, Piccino JD, Josgrilberg RS. Fenomenologia e análise do existir. São Paulo: Universidade Metodista de São Paulo;2000. p. 215-24.

Bueno GM. Variáveis de risco para a gravidez na adolescência. [online] Disponível em: <http://www.virtualpsy.org/infantil/gravidez.html>. [Acesso em 30 abr. 2006].

Bull S, Hogue CJ. Exploratory analysis o factors associated with teens' repeated chilbearing. J Health Care Poor Underserved.1998;9:42-61. 
Burrows R, Rosales ME, Alayo M, Muzzo S.Variables psicosociales y familiares asociadas con el embarazo de adolescentes. Rev Med Chile. 1994a;122:(5):713-20.

Burrows R, Rosales ME, Dias M, Muzzo S. Riesgo de embarazo temprano: construccion y validacion de un instrumento predictor. Rev Med Chile. 1994b; 122(5):510-6.

Cabral, CS. Gravidez na adolescência e identidade masculina: repercussões sobre a trajetória escolar e profissional do jovem. Rev Bras Est População. 2002;19(2):179-95.

Cabrera NJ, Tamis-LeMonda CS, Bradley RH, Hofferth S, Lamb ME. Fatherhood in the twenty-first century. Child Dev. 2000;71(1):127-36.

Cano MAT, Ferriani MGC. A família frente à sexualidade dos adolescentes. Acta Paul Enferm. 2000;13(1):38-46.

Capalbo C. A subjetividade em Alfred Schütz. Veritas. 2000;45(2):289-98.

Capalbo C. Fenomenologia e ciências humanas. 3ª ed. Londrina: UEL;1996.

Capalbo C. Metodologia das ciências sociais: a fenomenologia de Alfred Schutz. $2^{\mathrm{a}}$ ed. Londrina: UEL; 1998.

Carvalho GM, Acocella D. Adolescência: risco e prevenção para gravidez precoce e doenças sexualmente transmissíveis [monografia]. São Paulo: Centro Universitário São Camilo; 2003.

Carvalho GM, Antognetti M. Sentimento das adolescentes grávidas vinculadas ao serviço de pré-natal do programa de saúde da família da zona norte de São Paulo [monografia]. São Paulo: Centro universitário São Camilo; 2002.

Carvalho GM, Barros SM. Fatores psicossociais relacionados à gravidez na adolescência. Acta Paul Enferm. 2000;13(1):9-17.

Carvalho GM, Boulos LR, Garcia MT, Katz RH. Ser gestante: refletindo o cuidado da gestação ao nascimento. São Paulo: Centro Universitário São Camilo; 2005.

Carvalho GM, Franchi CC. O início da vida sexual feminina: algumas considerações [monografia]. São Paulo: Centro Universitário São Camilo; 2004.

Carvalho GM, Silva SS, Merighi MAB. Comportamento sexual de adolescentes e jovens universitários: conhecimento e uso dos métodos anticoncepcionais. In: $55^{\circ}$ Congresso Brasileiro de Enfermagem e $11^{\circ}$ 
Congresso Panamericano de Profissionales de Enfermerla; 2003 nov.10 -15; Rio de Janeiro.

Carvalho GM, Garcia MT, Garofalo EL, Katz RH, Boulos LR. Manual de orientações a puérperas e gestantes do Hospital Ipiranga. São Paulo: Secretaria de Estado da Saúde; 1997.

Carvalho GM, Garofalo EL. Implantação de um programa de interação de grupo como adolescentes por equipe multiprofissional em um hospital público do município de São Paulo. Rev Serv Soc Hosp Clin. 1998;5(1):23-7.

Carvalho GM, Merighi MAB, Frutuoso MFP. Nutrição do adolescente. In: Carvalho GM. Enfermagem e nutrição. São Paulo: EPU; 2005. p. 63-81.

Carvalho GM, Merighi MAB. Gravidez na adolescência. In: Carvalho GM. Enfermagem em ginecologia. São Paulo: EPU; 2004. p. 59-69.

Carvalho GM, Merighi MAB. Gravidez precoce: que problema é esse? São Paulo: Paulus/ Centro Universitário São Camilo; 2006.

Carvalho GM, Silva SS. Conhecimento e uso dos métodos anticoncepcionais por jovens e uma instituição universitária [monografia]. São Paulo: Centro Universitário São Camilo; 1999.

Carvalho GM. Enfermagem em ginecologia. São Paulo: EPU; 1996.

Carvalho GM. Enfermagem em ginecologia. 2a ed. São Paulo: EPU; 2004.

Carvalho GM. Fatores psicossociais relacionados à gravidez na adolescência [dissertação]. São Paulo: Universidade Federal de São Paulo; 1998.

Carvalho GM. Guia prático para evitar a gravidez. São Paulo: EPU; 1987.

Charpie-Dubrit M. La contraception a l'heure des maladies sexuellement transmissibles. Rev Med Suisse Romande.1991;111(2):133-9.

Clerget S. Adolescência: a crise necessária. Rio de Janeiro: Rocco; 2004.

Climent GI, Arias D, Spurio C. Maternidad adolescente: un camino hacia la marginación. Cuad Med Soc.2000;(77):81-97.

Coard S, Nets K, Park P, Felice M. Predictors of repeat pregnancy in urban adolescentes mothers. [abstract]. J Adolesc Health.1998, 22(2):173.

Cochran DL. African American fathers: a decade review of the literature. Fam Soc 1997;(78):340-51. 
Coley RL, Chase-Lansdale PL. Adolescent pregnancy and parenthood: recent evidence and future directions. Am Psychol. 1998; 53(20):152-66.

Costa COM. Fecundidade na adolescência; perspectiva histórica e atual. J Pediatr 1998;7(4):87-90.

Costa MC, Santos C, Sobrinho CL. Estudo dos partos e nascidos vivos de mães adolescentes e adultas jovens no Município de Feira de Santana, Bahia, Brasil, 1998. Cad Saúde Pública. 2002;18(3):715-22.

Cotes P, Aranha C, Barbi D. Mães antes da hora. Época; 2004 mar. 8; Seção Comportamento: 54-9.

Cowley C, Farley T. Adolescent girls' attitudes toward pregnancy; the importance of asking what the boyfriend wants. J Fam Pract. 2001; 50:603-7.

Cunha AA, Monteiro DLM, Reis AFF. Fatores de risco da gravidez na adolescência. In: Monteiro DLM, Cunha AA, Bastos AC. Gravidez na adolescência. Rio de Janeiro: Revinter; 1998. p. 43-56.

Dadoorian D. Gravidez na adolescência: um novo olhar. Psicol Ciência Profissão. 2003; 21(3):84-91.

Dallas CM, Chen SC. Experiences of African American adolescent fathers. West J Nurs Res.1998;20(2):210-22.

Dianni C. Um terço das adolescentes pobres usam a maternidade como projeto de vida. [online]. Disponível em: <http://www.amigasdoparto.org.br/ artigo_004-01.asp>. [Acesso em 28 mar. 2006].

Dias ACG, Gomes WB. Conversas em família sobre sexualidade e gravidez na adolescência: percepção das jovens gestantes. Psicol Reflex Crit. [online] 2000;13(1). Disponível em: <file://Psicologia\%20Reflexão\%20e \%20Crítica\% 20-\% 20BConversa s,\%20em520famíli... >. [Acesso em 16 abr. 2003].

Dias CJ. Prevenção em sexualidade na adolescência. Mundo Saúde 1997; 21 (2):75-81.

Dimenstein G, Lambert P. Sexo, aborto e AIDS explodem entre jovens. Folha de São Paulo, São Paulo; 1998 maio 03. Seção Cotidiano: 5.

Domínguez Gl. Varones adolescentes: los significados de la paternidad en la transición hacia los roles adultos. In: Bilac ED, Rocha MIB, organizadores. Saúde reprodutiva na América Latina e no Caribe. Temas e problemas. Campinas: PROLAPIABEP/NEPO/UNICAMP; 1998. p. 237-60.

Dotta IG, Noda E, Silva SLL, Wang MHJ. Gestação na adolescência. Rev Bras Méd. 2000;57:15-20. 
Elster AB, Hendricks L. Stresses and coping strategies of adolescent fathers. In: Elster AB, Lamb ME, organizadores. Adolescent fatherhood. Hillsdale: Laurence Erlbaum; 1986. p. 55-6.

Fávero MH, Mello RM. Adolescência, maternidade e vida escolar: a difícil conciliação de papéis. Psicol Teoria Pesq. 1997; 13(1):131-6.

Ferreira T. Prevenção da gravidez na adolescência deve considerar formação de identificação. [online]. Disponível em: <http://www.unifesp. br/comunicacao/jpta/ed159/ pesq3.htm >. [Acesso em 30 abr. 2006].

Fini MI. Sobre a pesquisa qualitativa em educação, que tem a fenomenologia como suporte. In: Bicudo MAV, Espósito VHC. Pesquisa qualitativa em educação. Piracicaba: UNIMEP; 1994. p. 23-33.

Folle E, Geib LTC. Representações sociais das primíparas adolescentes sobre o cuidado materno ao recém-nascido. Rev. Lat-Am. Enferm. 2004; 12(2):183-90.

Fonseca AL, Bastos AC. Maternidade adolescente em contexto cultural: um estudo com mães adolescentes de duas comunidades (uma urbana e uma semi-rural) na Bahia. Rev Bras Cresc Desenv Hum. 2001;11(1):86-98.

Fonseca JL. Paternidade adolescente: da investigação à intervenção. In: Arilha M, Ridenti SGU, Medrado B, organizadores. Homens e masculinidades: outras palavras. 2a ed. São Paulo: 34; 2001. p. 185-214.

Fustinoni SM. As necessidades de cuidado da parturiente: uma perspectiva compreensiva da ação social [tese]. São Paulo: Escola de Enfermagem, Universidade de São Paulo; 2000.

Galarza H, Gutierrez O, Muchaypiña R. Nivel de conocimientos sobre cuidados del recién nacido y su relación con los factores socioculturales en madres adolescentes primíparas, 1999. Lima: Instituto Materno Perinatal; 2000.

Garcia TR. Representações de gestantes adolescentes solteiras sobre aspectos de sua problemática psicossocial : implicações para a enfermagem obstétrica [dissertação] Ribeirão Preto: Escola de Enfermagem de Ribeirão Preto, Universidade de São Paulo; 1984.

Garcia TR. Cuidando de adolescentes grávidas solteiras, [tese]. Ribeirão Preto: Escola de Enfermagem de Ribeirão Preto, Universidade de São Paulo; 1996.

Garcia TR, Pelá NTR, Carvalho EC. Gravidez pré-conjugal em mulheres adolescentes. João Pessoa: Idéia; 2000. 
Godinho RA, Schelp JRB, parada CMGL, Bertocello NMF, Adolescentes e grávidas: onde buscam apoio? Rev Lat-Am Enferm. [periódico online]. 2000; 8(2). Disponível em: <http://www.scielo.Br/1>. [Acesso em 18 abr. 2006].

Gomes R, Fonseca EMGO, Veiga AJMO. La visión de la pediatria acerca del embarazo en la adolescencia: un estudio bibliográfico. Rev Lat-Am Enferm. 2002;10(3):408-14.

Gomes SEC. Gravidez na adolescência e sua recorrência [dissertação]. São Paulo: Escola de Enfermagem, Universidade de São Paulo; 2004.

Gordon CP. Adolescent decision making: a broadly based theory and its application to the prevention of early pregnancy. Adolescence. 1996; 31(123):561-82.

Gordon DE. Formal operational thinking: the role of cognitive development processes in adolescent decision-making about pregnancy and contraception. Am Journal of Orthopsychiatry. 1990;60(3):346-57.

Grossman E. O médico de adolescente e seu ofício: reflexões sobre as normas e a prática [dissertação]. Rio de Janeiro: Instituto Fernandes Figueira, Fundação Osvaldo Cruz; 1995.

Guimarães BEM. Gravidez na adolescência. In: Saito MI, Silva LEV. Adolescência: prevenção e risco. São Paulo: Atheneu; 2001. Cap. 28, p. 291-98.

Heath DT, McKenry PC. Adult family life of man who fathered as adolescents. Fam Soc. 1993;4(1):36-45.

Houaiss A, Vilar MS. Dicionário Houaiss da língua portuguesa. Rio de Janeiro: Objetiva; 2001.

Instituto de Estudios de Población y Desarrollo (IEPD). Madres adolescentes en la República Dominicana: informe general. $2^{\mathrm{a}}$ ed. Santo Domingo; 1996.

Jesus MCP. A educação sexual na vida cotidiana de pais e adolescentes: uma abordagem compreensiva da ação social [tese]. São Paulo: Escola de Enfermagem, Universidade de São Paulo; 1998.

Kahhale EP, Odierna IC, Galetta MA, Neder M, Zugaib MO. O desenvolvimento da sexualidade e da relação materno-filial em gestantes adolescentes. Rev Ginec Obst. 1997;8(1):23-9.

Levandowski DC, Piccinini C. Paternidade na adolescência: aspectos teóricos e empíricos. Rev Bras Cresc Desenv Hum. 2004;14(1):51-67. 
Levandowski DC, Piccinini CA. A interação pai-bebê entre pais adolescentes e adultos. Psic Reflex Crit. 2002;5(2):413-24.

Levandowski DC. Paternidade na adolescência: uma breve revisão da literatura internacional. Est Psicol. 2001;6( 2):195-209.

Levinson RA. Reproductive and contraceptive knowledge, contraceptive selfefficacy, and contraceptive behavior among teenage women. Adolescence. 1995; 30:65-85.

Lima CTB, Feliciano KVO, Carvalho MFS, Souza APP, Menabo JBC, et al. Percepções e práticas de adolescentes grávidas e de familiares em relação à gestação. Rev Bras Saúde Materno-Infantil 2004; 4(1):71-83.

Linares R, Romero G, Moreno H. Factores de riesgo de salud maternoinfantil en madres adolescentes de Colombia. Rev Panam Salud Publica. 1998; $4(2): 80-6$.

Longo LAFB. Juventude e contracepção: um estudo dos fatores que influenciam o comportamento contraceptivo das jovens brasileiras de 15 a 24 anos. Rev Bras Estudos de População 2002; 9(2):110-119.

Lucchiari DHS. O que é escolha profissional. $3^{a}$ ed. São Paulo: Brasiliense; 1988. p.17-74.

Luz AMH. Mulher adolescente: sexualidade, gravidez e maternidade. Porto Alegre: EDIPUCRS; 1999.

Lyra J. A Construção Social da Invisibilidade dos pais adolescentes nos dados demográficos [online]. In: $12^{\circ}$ Encontro Nacional de Estudos Populacionais; 1998. Disponível em: <www.abep.org.br>. [Acesso em $1^{\circ} \mathrm{abr}$. 2006].

Machado BRG. Influencia de la educación sanitaria en madres adolescentes en su conducta para lactar. Rev Cubana Med Integral. 2001;17(3):244-47.

Machado FN, Meira DC, Madeira AMF. Percepções da família sobre a forma como a adolescente cuida do filho. Rev. Esc. de Enferm USP. 2006; 37(1):11-8.

Madeira AMF, Tsunechiro MA. Crescer com o filho: a singularidade do adolescer mãe. In: Merighi MAB, Praça NS. Abordagens teóricometodológicas qualitativas: a vivência da mulher no período reprodutivo. São Paulo: Guanabara Koogan; 2003. p. 59-80.

Madeira AMF. Crescer com o filho: a singularidade do adolescer mãe [tese]. São Paulo: Escola de Enfermagem, Universidade de São Paulo; 1998. 
Maldonado MT. Psicologia da gravidez: parto e puerpério. 15a ed. São Paulo: Saraiva; 2000. p. 33.

Mandu ENT Gravidez na adolescência: um problema? In: Ramos FRS, organizadores. Projeto Acolher: um encontro da enfermagem com o adolescente brasileiro. Brasília (DF): Ministério da Saúde; 2001. p. 94-7

Marsiglio W, Cohan M. Young Fathers and child development. In: Lamb ME, organizadores. The role of the father in child development. $3^{\text {th }}$ ed. New York: John Wiley Sons 1997. p. 227-44.

Marsiglio W. Adolescent males' orientation toward paternity and contraception. Fam Plann Perspect. 1993;25(1):22-31.

Martins F, Bicudo MAV. A pesquisa qualitativa em psicologia: fundamentos e recursos básicos. São Paulo: Cortez; 1989.

Martins F, Bicudo MAV. Contribuição da fenomenologia à psicologia clínica: imaginação e fantasia. In: Martins J. Um enfoque fenomenológico ao currículo: educação como poiésis. São Paulo: Cortez; 1992.

Martins MOD. Mães adolescentes e o cuidado a seus filhos no primeiro ano de vida [dissertação] Salvador: Escola de Enfermagem, Universidade Federal da Bahia; 1999.

Medrado B, Lira J. Adolescência "desprevenida" e a paternidade na adolescência: uma abordagem geracional e de gênero, 1998. Disponível em: $<$ http://www.bireme.br/bvs/adolec $>$. [Acesso em 4 jan. 2006].

Melo MT. Estar grávida na adolescência: um estudo realizado no Hospital Regional de São José, SC. Psicol Soc. 2001;13(1):93-106.

Merighi MAB. A docência de enfermagem em uma universidade pública: um enfoque fenomenológico [dissertação]. São Paulo: Escola de Enfermagem, Universidade de São Paulo; 1993.

Merighi MAB. Enfermeiras obstétricas egressas da Escola de Enfermagem da Universidade de São Paulo: caracterização e trajetória profissional [tese]. São Paulo: Escola de Enfermagem, Universidade de São Paulo; 2000.

Monteiro DLM. Perfil socioeconômico da adolescente e adesão à contracepção. In: Monteiro DLM, Cunha AA, Bastos AC. Gravidez na adolescência. Rio de Janeiro: Revinter; 1998. p. 171-85.

Morais FRR, Garcia TR. Gravidez em adolescentes: visão de familiares. Mossoró: UERN;2003. 
Moreira CC. Fique alerta quando a adolescente engravida. Pediatr Mod. 1997; 33(5):320.

Neme B. Obstetrícia básica. $2^{\mathrm{a}}$ ed. São Paulo: Sarvier; 2000.

Nóbrega NP. O papel da parentalidade na construção do sujeito. In: D' Ávila Neto MI, Garcia CA, organizadores. Mulher: cultura e subjetividade.

Coletâneas da ANPEPP 1997;1(7):135-46.

Nogueira AT. Maternidade e paternidade. [online]. Disponível em:

$<\mathrm{http}$ ://www. amigasdoparto_maternidade.asp>. [Acesso em 28 mar. 2006].

Nunes CEG. Adolescência e paternidade: um duelo de papéis sociais.

Psicologia. 1998; 29(1):125-138.

Organización Panamericana de la Salud (OPS). Fondo de Población de las Naciones Unidas (FPNU). El embarazo en la adolescencia: lineamenos para el diseño de investigaciones de aspectos socioculturales. Washington (DC): OPS/ FPNU; 1992.

Out JW, Lafreniere K. Baby think it over ${ }^{\circ}$ : using role-play to prevent teen pregnancy. Adolescence. 2001;36(143):571-82.

Pais JM. Vida cotidiana: enigmas e revelações. São Paulo: Cortez; 2003.

Pantoja ALN. Ser alguém na vida: uma análise sócio-antropológica da gravidez / maternidade na adolescência em Belém do Pará, Brasil. Cad Saúde Pública 2003; 19 supl.2:335-43.

Parceval G. A parte do pai. Porto Alegre: L \& PM; 1986.

Paulics V. Atenção à gravidez na adolescência. [online]. Disponível em: $<$ http://www.federativo.bndes.gov.br/dicas/D074.htm>. [Acesso em 19 jun. 2006].

Persona L, Shino AKK, Tarallo MC. Perfil de adolescente com repetição da gravidez atendidas num ambulatório de pré-natal. Rev Lat-Am Enferm. 2004; 12(5):745- 50.

Piccinini CA, Rapoport A, Levandowski DC, Voigt PR. Apoio social percebido por mäes adolescentes e adultas: da gestação ao terceiro mês de vida do bebê. Psicologia 2002; 33(1):9-35.

Pinheiro VS. Maternidade na adolescência: significados e repercussões [dissertação]. Natal: Universidade Federal do Rio Grande do Norte; 2001.

Pinheiro VS. Repensando a maternidade na adolescência. Estud Psicol (Natal). 2000;5(1). [periódico online]. Disponível em: <file://A:IEstudos 
\%20de\%20Psicologia\%20(natal)\%20-\%20BRepensando\%20a\%20matern...> .[Acesso em 16 abr. 2006].

Pinto e Silva JL. Aspectos médico-sociais da gravidez na adolescência. In: Neme B. Obstetrícia básica. $2^{\text {a }}$ ed. São Paulo: Sarvier; 2000. Cap.135, p.1196-201

Pinto e Silva JP. Gravidez na adolescência desejada: versus não desejada. Femina 1998;26(10):825-30.

Ramos FRS. Bases para uma re-significação do trabalho de enfermagem junto ao adolescente. In: Projeto Acolher / Associação Brasileira de Enfermagem. Adolescer: compreender, atuar, acolher. Brasília (DF); 2001. p.11-8.

Resolução 196/96, de 10 de outubro de 1996, do Conselho Nacional de Saúde (CNS). Regulamenta pesquisas envolvendo seres humanos. Bioética.1996;4(2 supl):15-25.

Rezende J, Montenegro CAM. Obstetrícia fundamental. $9^{\mathrm{a}}$ ed. Rio de Janeiro: Guanabara-Koogan; 2003.

Rhein LM, Ginsburg KR, Schwarz DF, Pinto-MR JA, Zhao H, Morgan AP, et al. Teen father participacion in child rearing: family perspectives. Adolesc Health.1997;21:244-52.

Robinson BE. Teenage pregnancy from the father's perspective. Am J Orthopsychiatry.1988;58(1):46-51.

Rodrigues BMRD. O cuidar de crianças em creche comunitária: contribuição da sociologia fenomenológica de Alfred Schütz. Londrina: UEL; 1998.

Sabroza AR, Leal MC, Souza Junior PR, Gama SGN. Algumas repercussões emocionais negativas da gravidez precoce em adolescentes no município do Rio de Janeiro. Cad Saúde Pública [periódico online]. 2004; 20(1). Disponível em: <http://www.scielo.Br>. [Acesso em 18 abr. 2006].

Sadigurski CA. Um estudo sobre a descontinuação dos métodos contraceptivos na adolescência. Estilo de Viver 2001;1(4):11.

Santos SR, Schor N. Vivências da maternidade na adolescência precoce. Rev Saúde Pública. 2003;37(1):15-23.

Sari A. A interação na relação mãe-bebê em mães adolescentes. Rev Psiquiatria Rio Grande do Sul. 2002;24(3):261-8.

Sarmento R. Paternidade adolescente. In: Saito MI, Silva LEV. Adolescência: prevenção e risco. São Paulo: Atheneu; 2001. Cap. 30. p. 307-320. 
Schütz A. Fenomenologia del mundo social. Buenos Aires: Paidós; 1972.

Schütz A. El problema de la realidad social. Buenos Aires: Amorrortu; 1974a.

Schütz A. Estudios sobre la teoria social. Buenos Aires: Amorrortu; 1974b.

Schütz A, Luckman T. Las estructuras del mundo de la vida. Buenos Aires: Amorrortu; 1977.

Sciarra DT, Ponterotto JG. Adolescent motherhood among low-income urban hispanics: familial considerations of mother-daughter dyads. Qual Health Res. 1998;8(6):75-63.

Silva L, Tonete VLP. Gravidez na adolescência sob a perspectiva dos familiares: compartilhando projetos de vida e cuidado. Rev. Latino-Am Enferm. 2006;14(2): 199-206.

Silva ALAC, Rodrigues BMRD. A sociologia fenomenológica de Alfred Schütz e a possibilidade de compreender em enfermagem. Rev Enferm UERJ. 1996; (n. esp.):475-78.

SmithBattle L, Leonard VW. Adolescent mother four years later: narratives of the self and visions of the future. Ans Adv Nur Sei. 1998;20(3):36-49.

Sociedade Civil do Bem-Estar Familiar no Brasil (Bemfam). Brasil PNDS: Pesquisa Nacional sobre Demografia e Saúde, 1996. Rio de Janeiro: Bemfam/DHS; 1997.

Souza MMC. A maternidade nas mulheres de 15 a 19 anos: um retrato da realidade. Mundo Saúde. 1999;23(2):93-105.

Stevens-Simon C, Beach RK, Klerman LV. To be rather than not to be ... that is the problem with the questions we ask adolescentes about their childbearing intentions. Arch Pediatr Adolesc Méd. 2001;155:1298-300.

Stern C. El embarazo em la adolescência como problema público: uma visión crítica. Salud Pública Mex. 1997;39:137-43.

Takiuti A. Mitos e tabus da condição feminina. In: Anais do $5^{\circ}$ Congresso Brasileiro de Adolescência, $1^{\circ}$ Congresso da Associação Brasileira de Adolescência e $3^{\circ}$ Encontro do Comitê de Adolescência da América Latina, 1993; Belo Horizonte. p.268-71.

Teti DM, Lamb ME. Sex-role Learning and adolescent fatherhood. In: Elster AB, Lamb ME, organizadores. Adolescent fatherhood. Hillsdale: Lawrence Erlbaum; 1986. p. 19-30. 
Tocantins FR. As necessidades na relação cliente - enfermeiro em uma unidade básica de saúde: uma abordagem na perspectiva de Alfred Schütz, [tese]. Rio de Janeiro: Escola de Enfermagem Anna Nery, Universidade Federal do Rio de Janeiro; 1993.

Trindade E, Bruns MAT. Pai adolescente: quem ele é? Rev Bras Sex Hum. 1998; 9(1):23-8.

Trindade E, Bruns MAT. Adolescentes e paternidade: um enfoque fenomenológico. Ribeirão Preto: Holos; 1999.

Trindade ZA, Menandro MCS. Pais adolescentes: vivência e significação. Est Psicol. 2002;7(1):15-23.

Unbehaum SG 2001. a desigualdade de gênero nas relações parentais. In: Arilha M, Ridenti SGU, Medrado B, organizadores. Homens e masculinidades: outras palavras. $2^{\mathrm{a}}$ ed. São Paulo: 34; 2001. p. 163-184.

Urena FIC. El incremento de la maternidade adolescente en la República Dominicana, 1991-1996. Santo Domingo: Instituto de Estudos de Estudos de Población y Desarrollo; 1998.

Velásquez AMQ. Câmbios em la dinâmica familiar durante la gestación y el posparto. 1997. Disponível em: <http//www.tone.udea.edu.co/revista/mar97/ câmbios.htm>. [Acesso em 18 abr 2006].

Vieira M, Greenhalgh L, Vieira JL. Mãos dadas para a vida. Época 2000; (92):52-7.

Vitalle MSS, Amancio OMS. Gravidez na adolescência [online]. Disponível em: <www.brazilped news.org.br/set2001/bnpar101.htm>. [Acesso em 30 abr. 2006].

Vitiello N. Sexualidade na adolescência. Manual de apoio ao educador. São Paulo: Organon; [s.d.].

Wagner HR, organizador. Fenomenologia e relações sociais: textos escolhidos de Alfred Schütz. Rio de Janeiro: Zahar; 1979.

Walsh G. Introducción a obra de Alfred Schütz. In: Schütz A. Fenomenologia del mundo social. Buenos Aires: Paidós; 1972.

Westney OE, Cole OJ, Munford TL. Adolescent unwed prospective fathers: readiness for fatherhood and behaviors toward the mother and the expected infant. Adolescence.1986;21(84):901-11.

World Health Organization (WHO). Safe motherhood. Geneva; 1996. p. 6-8. 
World Health Organization (WHO). The reproductive health of adolescent: a strategy for action. Geneva; 1989.

Young M. Parenting during mid-adolescence: A review of development theories and parenting behaviors. J Matern Child Nurs. 1988; 17(1):1-12.

Zaher VL, Silva LEV, Leal MM. Saúde e trabalho. In: Saito MI, Silva LEV. Adolescência: prevenção e risco. São Paulo: Atheneu; 2001. Cap.18. p.18798. 


\section{BIBLIOGRAFIA COMPLEMENTAR}

Branco VMC. Gravidez na adolescência: problema para quem? Interação 1997 jan./mar.; 6-7.

Cabral C. Contracepção e gravidez na adolescência na perspectiva de jovens pais de uma comunidade favelada do Rio de Janeiro. Cad Saúde Pública. 2003; 19 supl. 2:283-92.

Carvalho A, Salles F,Guimarães M, organizadores. Adolescência. Belo Horizonte; Editora UFMG / Proex- UFMG; 2003.

Costa MC, Santos C, Sobrinho CL. Estudo dos partos e nascidos vivos de mães adolescentes e adultas jovens no Município de Feira de Santana, Bahia, Brasil, 1998. Cad Saúde Pública 2002;18(3):715-722.

Monteiro DLM, Cunha AA, Bastos AC. Gravidez na adolescência. Rio de Janeiro: Revinter; 1998.

Gama SGN, Szwarcwald CL, Sabroza AR, Branco VC, Leal MC. Fatores associados à assistência pré-natal precária em uma amostra de puérperas adolescentes em maternidades do Município do Rio de Janeiro, 1999-2000. Cad Saúde Pública 2004; 20 supl.1:S101-11.

Gauderer EC. Socorro, meu filho é um adolescente! Rio de Janeiro: DP\&A; 1999.

Golse B. O desenvolvimento afetivo e intelectual da criança. $3^{\mathrm{a}}$ ed. Porto Alegre: Artmed; 1998. p. 170-257.

Harris JLJ. Urban African American adolescent parents: their perceptions of sex, love, intimacy, pregnancy and parenting. Adolescence. 1998;33(132): 833-44.

Hercowitz A. Gravidez na adolescência. Pediatr Mod. 2002; 38(8):392-5.

Tiba I. Adolescentes: quem ama, educa! São Paulo: Integrare; 2005.

Machado NO. Caracterização nutricional de uma população de mães adolescentes [dissertação]. São Paulo: Faculdade de Saúde Pública, Universidade de São Paulo; 2001.

Mellamby AR, Pearson VAH, Tripp JH. Preventing teenage pregnancy. Archives of Disease in Childhood. 1997;77:459-62. 
Miranda MIF, Ferriani MG. Políticas públicas sociais para crianças e adolescentes. Goiânia: AB; 2001.

Mngadi PT, Zwane IT, Ransjö-Arvidson AB, Ahlberg BM, Thembi IT. Quality of maternity care for adolescent mothers in Mbabane, Swaziland. Int Nurs Rev. 2002;49(1):38-46.

Oliveira MW. Gravidez na adolescência: dimensões do problema. Cad. CEDES 1999;19(45):48-70.

Peres F, Rosemburg CP. Desvelando a concepção de adolescência / adolescente presente no discurso da saúde pública. Saúde Soc 1998;7:5386.

Piccinini CA, Rapoport A, Levandowski DC, Voigt PR. Apoio social percebido por mäes adolescentes e adultas: da gestação ao terceiro mês de vida do bebê. Psicologia. 2002;33(1):9-35.

Romanelli G. Autoridade e poder na família. In: Carvalho MCB, organizadora. A família contemporânea em debate. São Paulo: EDUC/ Cortez; 2002. p. 73-88.

Sarti CA. Família e individualidade: um problema moderno. In: Carvalho MCB, organizadora. A família contemporânea em debate. São Paulo: EDUC/ Cortez; 2002. p. 39-49.

Souza IF. Gravidez na Adolescência: Uma questão social. Adolesc Latinoam Porto Alegre. 2002; 3(2). Disponível em: <http://raladolec.bvs.br/script=sci_ar tex\&pid=S1414. $>$. [Acesso em $1^{\circ}$ set. 2004].

Strasburger VC. Os adolescentes e a mídia: impacto psicológico. Porto Alegre: Artes Médicas Sul; 1999.

Thompson PJ, Powel MJ, Patterson RJ, Ellerbee SM. Adolescent parenting: outcomes and maternal perceptions. JOGNN. 1995;24:713-8.

Universidade de São Paulo. Faculdade de Saúde Pública. Guia de apresentação de teses. 2a ed. São Paulo: A Biblioteca; 2006.

Wagner A, Falcke D, Meza EBD. Crenças e valores dos adolescentes acerca de familia, casamento, separação e projetos de vida. Psicol Reflex Crit. 1997;10(1). Disponível em: <http://www.scielo.br/scielo>. [Acesso em 27 maio 2006].

Zagonel IPS, Neves EP. O ser adolescente gestante em transição: um enfoque de cuidar-pesquisar sob a ótica da enfermagem. Rev Bras Enferm. 2002; 55(4):408-13. 


\section{ANEXOS}




\title{
ANEXO I
TERMO DE CONSENTIMENTO E ESCLARECIMENTO PARA PARTICIPAR DE PESQUISA CIENTÍFICA

\author{
Título da pesquisa: RECORRÊNCIA DA PARENTALIDADE NA ADOLESCÊNCIA NA \\ PERSPECTIVA DOS SUJEITOS ENVOLVIDOS
}

Eu, Geraldo Mota de Carvalho, enfermeiro obstetra, aluno do Programa de Doutorado da Escola de Enfermagem da Universidade de São Paulo, estou realizando um estudo com o objetivo de conhecer e compreender como é constituída a percepção que os adolescentes têm da maternidade/paternidade recorrente na adolescência. Sendo você, então, um(a) adolescente pai (mãe), mais de uma vez, gostaria de entrevistá-la(o) para que eu possa realizar esta pesquisa.

Este estudo não tem ligação alguma com nenhuma instituição assistencial.

Você terá apenas de dispor de alguns minutos de seu tempo para me contar um pouco da sua experiência ou situações vivenciadas durante o processo da maternidade / paternidade. Sua participação será importante para que nós, profissionais da área da saúde conheçamos sua experiência e, desta forma, poder contribuir para a assistência a outros adolescentes nas mesmas circunstâncias.

Deixo claro que suas respostas são confidenciais, mantendo assim seu anonimato e você terá a liberdade de retirar seu consentimento a qualquer momento, deixando de participar da pesquisa.

A entrevista será realizada em uma sala privativa e seu conteúdo será gravado. Todas as informações serão mantidas em sigilo e identificadas sob um pseudônimo de conhecimento apenas do pesquisador. As fitas das entrevistas serão guardadas em local seguro e trancado por um período de cinco anos, após o término da pesquisa.

Os resultados do estudo serão divulgados em reuniões e publicações científicas. Promoverão o planejamento de uma melhor assistência de Enfermagem, com o objetivo de ajudar os adolescentes a viverem a experiência da gravidez / maternidade / paternidade, da melhor maneira possível.

\section{CONSENTIMENTO PÓS-INFORMADO}

Entendo que as informações serão confidenciais, não havendo identificação nominal, que não sofrerei nenhum tipo de sanção, caso desista de participar deste estudo. Sou livre para não querer participar do estudo, podendo deixar de responder qualquer pergunta se assim o desejar.

Se tiver dúvidas sobre o estudo, entrarei em contato com o pesquisador pelos números de telefones: 9787-6220 ou pelo endereço eletrônico: mrgem@uol.com.br ou com a secretaria do Comitê de Ética em Pesquisa (CeP) da Universidade de São Paulo por meio do número 3066 -7548.

Este documento contém duas vias, uma ficará em meu poder e a outra arquivada com o pesquisador.

Assim, declaro que tendo compreendido o que foi explicado, concordo participar da pesquisa de forma voluntária e não me oponho que a entrevista seja gravada. 


\begin{abstract}
ANEXO II
SOLICITAÇÃO DE AUTORIZAÇÃO PARA PESQUISA
\end{abstract}

São Paulo, 22 de abril de 2005

\author{
À Diretoria da Divisão de Enfermagem \\ Hospital Ipiranga \\ Sra. Sandra Cristina Perez Tavares \\ Av. Nazaré, 28 - Ipiranga \\ São Paulo - SP \\ 04262-000
}

Eu, Geraldo Mota de Carvalho, enfermeiro obstetra, funcionário deste Hospital e aluno do Programa de Doutorado da Escola de Enfermagem da Universidade de São Paulo, estou realizando um estudo sobre a recorrência da maternidade/paternidade na adolescência, gostaria de fazer contato com adolescentes mães/pais recorrentes, para entrevistá-los a fim de continuar minha pesquisa.

Este estudo não tem ligação com nenhum hospital, maternidade ou outra instituição assistencial, entretanto gostaria que o contato inicial com os adolescentes fosse feito nessa instituição. As entrevistas poderão ser realizada nas dependências do Hospital ou nos locais onde os sujeitos desejarem.

Esclareço que não haverá identificação da instituição ou do entrevistado e todo processo dar-se-á em consonância com a Resolução 196/96 que trata de pesquisas com seres humanos e, conforme projeto, em anexo, aprovado em exame de qualificação da Universidade de São Paulo.

Os resultados do estudo promoverão o planejamento de uma melhor assistência de enfermagem, com o objetivo de ajudar os adolescentes a viverem a experiência da gravidez/maternidade/paternidade, da melhor maneira possível.

Coloco-me à disposição para quaisquer esclarecimentos que se fizerem necessários por meio dos números de telefones: 5072-3960 ou 9787-6220, pelo endereço eletrônico: mrgem@uol.com.br , ou pelo endereço residencial: Rua Guiratinga, 931 apto 113, Saúde, São Paulo, SP, 04141-001.

Atenciosamente, 


\section{ANEXO III GEMAS E TERMINOLOGIAS AFINS}

Gema é um termo que tem sua origem na língua latina, gemma/ae, e é o mesmo que pedra preciosa; pedra usada como adorno pessoal. A maioria é constituída por minerais, mas há as de origem orgânica, as artificiais (produzidas em laboratório, sem correspondente natural) e as sintéticas (confeccionadas em laboratório, para as quais existem equivalentes naturais).

Gemologia, a ciência que tem por fim identificar a natureza das gemas e classificá-las.

Garimpo é o local onde se exploram minerais e metais preciosos; atividade, prática ou ofício de garimpeiro.

Garimpagem é o ato ou efeito de garimpar; atividade artesanal desenvolvida pelo garimpeiro, mineiro ou minerador, nos aluviões, grupiaras, nos leitos ou às margens dos rios e que consiste na exploração de minerais e metais preciosos ou úteis, utilizando-se instrumentos rudimentares. Também em sentido figurado garimpagem significa a pesquisa minuciosa de palavras, expressões, textos, etc., a procura meticulosa de coisas valiosas a partir da coleta de determinado material.

Apropriando-me da terminologia acima, creio que poderei fazer uma analogia entre a atividade do garimpo e a de pesquisa. $O$ meio acadêmico é semelhante a uma mina, onde 0 pesquisador é um mineiro, um garimpeiro do conhecimento e, no caso específico deste estudo, os adolescentes com suas preciosas contribuições, são as gemas.

Sendo assim, denominei os sujeitos desta pesquisa com nomes de gemas, sobre as quais faço, a seguir, um breve comentário, a título de curiosidade. São os pais: Diamante, Jacinto, Crisólito, Ônix, Topázio e as mães: Esmeralda, Jade, Turmalina, Jaspe, Safira, Rubi, Água-marinha, Pepita, Ágata, Marcassita.

Diamante: uma das gemas mais preciosas; caracteriza-se pela sua transparência, dureza, brilho e beleza.

Turmalina: mineral, geralmente, trigonal, de coloração variada; Turmalina verde é o mesmo que Esmeralda-do-Brasil.

Jaspe: variedade de Calcedônia muito usada em razão das múltiplas cores que apresenta. A Calcedônia, por sua vez, é uma variedade de Quartzo; mineral transparente ou translúcido. Freqüentemente, encontrada na região de Cartago; do Grego Karkhēdónios que significa "de Cartago".

Safira: variedade transparente de Coríndon de grande valor; de cor azul.

Rubi: variedade de Coríndon de cor vermelha de alto valor gemológico.

Água-marinha: pedra semipreciosa, dura, transparente e brilhante. Muito encontrada no Brasil e, assim, chamada por sua cor azul-claro ou verde-mar.

Pepita: espécie de Ouro; grão ou fragmento de metal nativo.

Ágata: variedade de Calcedônia; apresenta anéis concêntricos geralmente de várias cores. Marcassita: gema de brilho metálico; nome pelo qual se designam a Pirita, a Hematita, o Aço e a própria Marcassita, bem como outras substâncias de brilho metálico.

Jacinto: pedra preciosa de cor azul; mesmo que Zircão.

Jade: caracteriza-se como minerais duros, compactos e esverdeados. Designa a Jadeíta (de cor variável, especialmente verde, é o mais raro e valioso dos tipos de Jade) e a Nefrita (de cor esverdeada ou azulada; pensava-se, na Idade Média, que tal pedra curava os rins).

Esmeralda: pedra preciosa transparente de cor verde; espécie de Jaspe verde.

Crisólito: espécie de pedra preciosa de cor verde-amarelada clara.

Ônix: variedade de Ágata Calcedônia, consistindo em faixa retas e paralelas, alternadas de diferentes cores.

Topázio: de cor variável; uma das mais importantes pedras preciosas; destaque para o Topázio imperial, encontrado em Ouro Preto, MG, que apresenta coloração alaranjada.

Fonte: Houaiss A, Vilar MS. Dicionário Houaiss da Língua Portuguesa. Rio de Janeiro: Objetiva; 2001. 


\section{ANEXO IV}

\section{DISCURSOS DAS MÃES}

Turmalina, 17 anos de idade, teve o primeiro filho aos 15 anos com um namorado de 22 anos. Ficou com o pai da primeiro filho por alguns meses e separou-se dele quando a criança filho tinha uns 15 dias de vida. Atualmente vive em união consensual desde o início da segunda gravidez, com o pai desta criança, com 15 dias de vida. Interrompeu os estudos no primeiro ano do ensino médio por motivo da segunda gravidez. O pai do segundo filho tem 26 anos, trabalha como porteiro de edifício e já tem uma filha de outro relacionamento que mora com sua ex-namorada.

P- Como foi para você ser mãe pela primeira vez?

E- Ah! pra mim foi bom, foi uma experiência! A primeira gravidez não foi programada. Quando engravidei, ficamos juntos por um certo tempo, cada um na sua casa, até quando o bebê tinha 15 dias, a gente se separamos. Dois meses depois voltamos, aí, depois vi que não tinha como dar certo e se separamos definitivamente ... tinha muito ciúmes.

P- Como aconteceu o nascimento do outro filho?

E- A gravidez foi um trauma [ri], eu tinha 16 anos, o parto foi normal ... Eu gostei de ser mãe, mas foi um trauma no instante que eu soube que estava grávida. Eu não queria ficar, não estava planejada, estava namorando ... depois que eu soube foi um susto ... a gravidez foi um caos ... ficava pensando, um com dois anos. ... Um pequenininho ainda e outro menor ainda e eu ainda estou um pouco assustada. Minha mãe mora um pouco distante, mas vai me ajudar a cuidar do maior, por enquanto. Meu medo, meu medo, é ter outro baque, tipo, se separar de novo. O primeiro filho sem ... com o pai distante ... o segundo com o pai distante ... estou disposta a enfrentar o que vim...

P- Como é ser mãe, mais de uma vez, ainda adolescente?

E- Eu sou um boa mãe, mas nem tanto [ri] . Minha mãe fala que eu sou muito bruta com ele, mas ele é um pouco levado. Eu acho que sou boa mãe ... ele faz dois anos, sábado, agora. ... Não sou um mãe muito carinhosa, eu não vou dizer que sou ... uma mãe grudada, não, eu não sou ... Eu sou carinhosa, assim, um pouquinho ele lá e aqui. Assim, quando eu posso, quando tenho um tempo disponível, eu vou e brinco com ele um pouquinho ... cuidando da casa no momento, eu não tou cuidando. Tem gente que tá 
cuidando, minha mãe paga uma moça para cuidar da casa. Eu acho que sou boa mãe, minha mãe acha que só ela é a melhor ... só ela que cuida bem dele e, pronto!

Foi uma experiência muito séria, mas estou achando maravilhoso! ... Estou encantada com eles. Eu aconselho as outras meninas para estudar, construir sua vida primeiro, depois, sim, pensar em construir uma família. Agora, eu não dou conselho a ninguém.

P- O que você espera do futuro sendo mãe tão jovem?

E- O espero é estudar, eu quero fazer Direito ... Pretendo, né? ... Trabalhar futuramente como advogada e cuidar dos meus filhos, só isso. Meus filhos ... mesma coisa estudar, trabalhar ... não trabalhar muito cedo ... estudar, se formar e depois começar a trabalhar. E tudo de bom no nosso relacionamento, quero que a gente seja muito feliz [com o companheiro]. Ele aceitou meu primeiro filho ... teve que aceitar .. tava tudo junto. Ele também tem uma filha que fica com a mãe.

Jaspe, 19 anos de idade, dois filhos de quatro e dois anos, teve o primeiro filho aos 15 anos com o namorado de 16 anos e o segundo, aos 18 com o mesmo namorado que tinha cerca de 18 anos. Ficou em união consensual com o pai das crianças por cerca de três anos, hoje, mora só em um apartamento alugado. Por decisão de ambos, as crianças estão morando com o pai e sua namorada, com quem ele tem um filho. Já teve outros namorados. Completou o ensino médio. Trabalha em vendas com seu pai. Nos primeiros meses de vida do seu primeiro filho, os pais de seu namorado sugeriram que eles ficassem com a guarda do filho.

\section{P- Como foi para você ser mãe pela primeira vez?}

E- É muita responsabilidade, assim. Olha, de um lado é bom, porque ser mãe é único! Agora, de outro lado tem a idade que, pela idade, perde toda a adolescência. Ao invés de você sair, ir curtir, viajar, tem que cuidar dos filhos, já são outras responsabilidades. O fato é assim: não é que atrapalha, mas depois que você tem o filho, você tem que se dedicar a ele. Quando que com 15 anos, eu poderia tá fazendo minha festa de 15 anos, poderia viajar, várias outras coisas, poderia ter feito minha faculdade. Hoje tenho que trabalhar, não posso ficar com eles [os filhos], porque onde trabalho é longe (trabalha em tempo integral). Então, eu passo minha responsabilidade toda para o pai deles, por algum tempo, né ? [Nesse momento, entra na sala o filho mais novo chorando porque o mais velho lhe jogou refrigerante, e ela carinhosamente o abraça consolando, pedindo para não chorar para não atrapalhar a entrevista. Ele compreende e pára imediatamente. A entrevista foi feita em um final de semana quando ela normalmente fica com as crianças]. Porque, agora, eles estão morando com ele. Então, é isso ... 
Se eu pudesse ter a opção ... [corrige] ... se me dessem duas opções: ter tido os filhos ou não, eu esperaria um pouco mais. Depois você quer viver a adolescência que você não viveu, aí, fica tudo bagunçado.

\section{P- Como aconteceu o nascimento do outro filho?}

E- Ah! ... [neste momento, sorri com prazer e abraça o filho menor que permaneceu a seu lado até o fim da entrevista]. Ah!, tava mais experiente, né ? Já sabia, não estava tão perdida. A gente tava junto [ela e o pai da criança], já foi mais esperado. Do primeiro, foi mais um sopetão. Do segundo, eu não fiquei tão perdida, já sabia como cuidar, tudo. Foi mais fácil. Fui uma mãe melhor.

\section{P- Como é ser mãe, mais de uma vez, ainda adolescente?}

E- Acho que vai ser melhor mais pra frente porque a nossa diferença de idade é pouca ... mais pra frente vai ser melhor. A gente vai ter um diálogo melhor. Não assim, com eu, eu escondia muita coisa do meu pai. Eu não quero que eles escondam as coisas pra mim. Acho que o diálogo vai ser melhor. A gente vai ter mais afinidade. A gente conversa muito! Eles são muito obedientes, é uma grande vantagem pra mim. O que eu acho que está certo, eu digo e falo: é isso, isso e isso. Não tem muito nhem, nhem, nhem, ficar em cima, porque eles sabem disso [fala rindo, muito descontraída]. Ai! Eu queria ser uma mãe melhor, eu queria ficar mais com eles. Quando eles ficavam mais comigo, a gente ficava mais junto. Era o inverso, quando eles ficavam comigo e viam o pai no final de semana. $O$ pai que era bom. Agora, que trabalho longe, eles ficam com o pai e me vêem no final de semana e, eu é que sou legal. Antigamente, eu era a mãe chata porque brigava e dava educação e, o pai só levava para passear. Agora, é o contrário. O pai é chato e a mãe é legal. Mas, eu pretendo mesmo, pegar eles de volta. O que falta é isso, dar mais atenção, porque eu não tenho o convívio com eles. Eu já reparei que, com o menor, eu tenho mais cuidado. Não, mais afeto, mas, talvez, isso seja uma falha minha ... que eu acho que não pode, mas é porque é menor ...

P- O que você espera do futuro sendo mãe tão jovem?

E- Eu penso, eu queria como todo mundo uma vida estável, ter uma casa, estar bem financeiramente, ter os meus filhos ao meu lado. Quero que mais pra frente tenham um bom estudo, uma faculdade. Ah! Não sei, acho que ... Não quero mais casar, não [ri] mas eu penso em ter outro filho sim ... Acho que mais um ... Não sei ... mais dinheiro ... pretendo fazer um curso ou uma faculdade, mas, no ramo que trabalho ... vendas ... trabalho no departamento de vendas de cilindros hidráulicos. 
Safira, 19 anos de idade, três filhos [cinco anos, três anos e um de oito meses]. Teve o primeiro filho aos 14 anos com o namorado de 16 anos; o segundo e terceiro são do atual namorado com quem esteve em união consensual por algum tempo e agora está casada. Completou o ensino médio. Trabalha como faxineira e leva o filho mais novo para o trabalho; o primeiro e segundo ficam em creche durante sua jornada de trabalho.

\section{P- Como foi para você ser mãe pela primeira vez?}

E- A primeira vez, assim, eu não queria a gravidez. O pai dele queria que eu tirasse mas, eu não queria tirar, mas depois ele nasceu. Eu fiquei, tipo, sozinha ... me sentia sozinha! Eu não ligava muito pra ele! Não dava aquele amor de mãe! Não gostava dele! Fui gostar dele mesmo, quando ele tinha nove meses. Não sabia cuidar de criança , cuidava na marra, né? Tinha 14 anos quando ele nasceu ... eu não cuidava bem dele. ... Eu aprendi a cuidar de criança na marra! Eu era sozinha, eu era criada pela minha avó Minha avó me ensinava a cuidar de criança ... Eu não tenho pai, nem mãe, eles são falecidos. Minha mãe é falecida, meu pai é vivo, traficante, matador, esses negócio ... Ele saiu da cadeia e a gente brigava muito. Aí eu saí de casa e pedi ajuda no conselho tutelar ... Eu era de menor e eles me mandaram pra um abrigo. ... Fui morar num abrigo com meu primeiro filho, lá na Vila Mariana, chamava Santa Fé. E lá eles viram que meu filho estava desnutrido ... eles que viram que meu filho estava desnutrido ... não era por falta de comida ... Eu que não sabia cuidar... Depois aprendi amar ele ... aí amei ele como amo agora, né? Depois de nove meses comecei amar ele, como amo agora. Aí, quando ele tinha três anos queria engravidar de novo ... Só que eu tomava aquela injeção "Deprovera" [Depo-provera $®$ ] todo mês pra prevenir. Demorou um ano para eu engravidar. O pai do primeiro só registrou, não ajudou em nada e eu conheci o pai das outras crianças quando o primeiro tinha um ano e pouco ... Ele me ajudou até hoje ... Aí, a gente casamos no papel ... casei depois de três anos amigados. Aí a $\mathrm{R}$ [segunda filha] veio e eu já sabia cuidar mais de criança, porque meu filho ficou desnutrido ... Aí, eu coloquei ele numa creche de criança desnutrida ... lá eles me ensinaram como era cuidar de criança, porque eu não sabia cuidar. Cheguei num ponto crítico de chegar deixar ele desnutrido mesmo. Não conseguia amamentar ele direito, não tinha paciência pra nada, queria saber de sair, ir pra balada, queria sair pra curtir. Só depois que tive a $\mathrm{R}$ é que eu virei mãezona mesmo, dona de casa. Não saio de casa pra nada, só cuido deles, trabalho também ... é isso! ... Trabalho em casa de família levo a R [R também é a criança de oito meses que esteve no seu colo durante a entrevista] pro meu serviço ... eu dou conta do meu serviço e dela ... Depois da $R$ eu não me cuidei. Aí veio a $R$ [a terceira criança] eu não ía tirar a $R$ também, né?, e ela tá aqui firme e forte. Eu sempre quis amamentar a R, mas ela nasceu com malformação no ãnus ... Ela tinha o canal, mas não tinha o ânus perfurado ... ela não tinha o ânus, o canal do ânus era ligado com o da vagina ... Ela fazia tudo pela vagina. Aí, com 21 dias ela foi queimada ... minha vó queimou ela ... 
ela acendeu um vela perto dela ... ela foi queimada [no braço]. ... Eu fiquei um mês e quinze dias no Hospital das Clínicas, ela fez enxerto, agora, tá pra fazer cirurgia plástica. Aí, então, sai do hospital, ela [ a segunda filha] tinha cinco ou seis meses. Aí, eu engravidei da última. Tive a filha, foi melhor mais ainda, porque eu aprendi a cuidar mais. Ela tá com oito meses, mama no peito, come de tudo. Meu sonho ... nossa! ... Meu sonho era amamentar, porque não pude amamentar a segunda e nunca consegui amamentar o primeiro, porque não tinha paciência e ele ficou internado também ... Então, ela [olhando pra filha nos seus braços] eu pude amamentar. Ah!, eu cuido deles muito bem. [ela chegou no local da entrevista com as duas crianças no mesmo carrinho com brinquedos e mamadeira com leite para a de três anos]. Quando ele [primeiro filho] tinha um ano e pouco eu já sabia cuidar mais de criança ... Depois que eu tive a segunda criança, é que eu aprendi ... antes só queria ir pra balada.

\section{P- Como aconteceu o nascimento do outro filho?}

E- Eu fiquei super feliz, eu queria uma menina, eu queria uma e Deus mandou duas! Foi melhor, mais ainda, eu aprendi cuidar mais. Eu aprendi a cuidar com a creche.

P- Como é ser mãe, mais de uma vez, ainda adolescente?

E- É bom. Não aconselho a ter cedo. Se puder esperar, é melhor ... perde a juventude.

P- O que você espera do futuro sendo mãe tão jovem?

E- Ah! O meu sonho é que dou uma coisa melhor pros meus filhos, coisa que eu não tive, um amor de mãe, um amor de pai ... fazer eles estudar, não perder a juventude como eu perdi minha juventude. Não quero que elas cresça com 14, 15 anos igual eu. Tive filho cedo ... quero que elas esteja estudando, fazendo uma coisa que elas gosta. Vou ensinar pra elas o que é errado, o que é certo... Não vou incentivar elas a ter ... sei que agora é difícil segurar uma filha ... mulher pra não ter relação, né? Mas eu vou ensinar, ensinar que existe preservativo, que tem injeção, pílulas, vários métodos têm pra não engravidar.

Eu quero uma casa no meu nome, um canto meu, com meus filhos, parar de pagar aluguel ... Viver em paz com eles, voltar a estudar ... Ela vai tá maiorzinha [olhando para a criança do colo] ... meus dois filhos ficam na creche ... Ela tô esperando a vaga ... eu levo ela [a criança de oito meses que está no seu colo durante a entrevista] pro meu serviço ... Eu dou conta do meu serviço e dela ... No meu primeiro ... eu era uma mãe desnaturada ... eu deixava ele sozinho ... eu deixava com minha irmã que era mais nova do que eu [menos de 14 anos] e saía, ia pro baile e voltava no outro dia ... minha vó brigava comigo. 
O pai delas tem 22 anos, trabalha e tá no segundo ano do curso médio, Ele tá fazendo o curso à noite, segunda, quarta, sexta. Depois que ele terminar o supletivo, também, eu é que vou fazer o supletivo, também, para ver se consigo um emprego melhor, também, né? Tenho estudo.

Rubi, 19 anos de idade, dois filhos de 1,8 anos [nasceu prematuro com mais ou menos sete meses] e outro de duas semanas que também nasceu prematuro com 36 semanas. Teve o primeiro filho aos 17/18 anos com o namorado, um ano de idade mais que a sua na época. O segundo filho é de outro namorado de 19 anos com quem mora na casa da mãe dele. Estudou até o segundo colegial e não trabalha. Sua mãe ajuda a cuidar do primeiro filho. Vive em união consensual. O companheiro trabalha como garçom.

P- Como foi para você ser mãe pela primeira vez?

E- Ah! Foi bom, porque eu queria, queria mesmo. Tinha mais ou menos 18 anos ... a primeira vez eu quis! Eu estava namorando, e eu quis. Foi uma experiência boa!

P- Como aconteceu o nascimento do outro filho?

E- O segundo também foi bom, porque meu marido, ele, queria muito ter um filho. Não foi assim pra falar, planejada, não! Eu tomava anticoncepcional e tudo, mas, aconteceu, o anticoncepcional falhou.

P- Como é ser mãe, mais de uma vez, ainda adolescente?

E- É bom, é bom ... Ah! Claro, a gente tem uma certa insegurança, assim, na parte de educar, criar, mas é bom, a gente vai aprendendo. Eu tenho ... eu tenho ainda um pouco de insegura... tanto que meu filho mais velho mora com ela [a mãe] ... que [o filho mais velho] nasceu antes do tempo com sete meses. Pra mim ... eu fico um pouco insegurança assim, mas tenho vontade de acertar. Eu tenho ajuda da minha mãe, ... meu marido fica do meu lado. Então, isso ajuda mais a gente, fica mais segura pra criar ele e tudo. Não, eu não aconselho a ter, assim como, a não ter filho cedo ... Eu deixo pra cada pessoa ... Eu acho que até os seus 17 anos, assim, pra ter filho, acho que não é bom! A pessoa tem que estudar mesmo, ver o que quer, depois pensa isto ... Agora com 18, 19 anos a pessoa já está um pouco mais madura, já sabe o que quer ...

Uma coisa de ruim de ter filho cedo é que agora, eu não vou poder continuar estudando. Mas um coisa de bom é que a gente pega experiência de vida e tudo, amadurece bastante, tem responsabilidade. Pra meu namorado, também, pra ele vais servir pra amadurecer bastante como pai ... que ele queria o filho. Então, eu acho que ele já estava se preparando pra isso. 
P- O que você espera do futuro sendo mãe tão jovem?

E- Por agora, acho que a única coisa que eu quero mesmo, é arrumar minha casa e tudo ... pra eles [os filhos] ter um cantinho deles também, né? Quando eles crescer, ter um lugarzinho pra eles ... Os estudos deles. Agora, meu pensamento é neles, não vai muito pra mim, é mais pra eles agora.

Meu relacionamento acho que vai continuar do mesmo jeito ... Não vai mudar muita coisa, não! Eu gostaria de voltar a estudar, mas agora vai ficar muito difícil com os dois. Eu queria terminar a escola e tudo ... Mas, assim, de profissão eu queria adquirir Medicina.

Outros filhos por enquanto, não [ri] ... Meu marido quer, mas eu não quero, não! ... Mas ... até lá ... eu não quero agora por causa disso mesmo ... a situação financeira ... Você tem que ter uma boa condição, assim, pra cuidar deles. Não adianta você tá colocando filho no mundo, um atrás do outro, mas você não tem condições e eles não vão ter nada. É melhor parar!

Água-marinha, 18 anos de idade, dois filhos de 1,5 anos [nasceu com mais ou menos 37 semanas de gestação] e outro de 15 dias, que também nasceu com cerca de 37 semanas de gestação.. Parou de estudar no $3^{\circ}$ ano do ensino médio pro causa da primeira gravidez. Não trabalha. Vive em união consensual com rapaz de 22, desde os 14 anos.. Namorou seu companheiro desde 12 anos. Mora em casa própria de dois cômodos no mesmo terreno da casa de seus pais. O companheiro trabalha como metalúrgico.

P- Como foi para você ser mãe pela primeira vez?

E- Eu adorei! Adorei porque eu já estava planejando. Já estava tendo um relacionamento com ele. Eu namorava ele desde os 12 anos e a gente já estava morando junto. Foi mais difícil pela falta de experiência, mas minha mãe me ajudou no resguardo. Mas, eu não tive insegurança, eu cuidava de criança pra fora.

\section{P- Como aconteceu o nascimento do outro filho?}

E- Meu segundo foi um acidente. Eu estava tomando remédio. Aí, estava fazendo mal ... eu tinha um distúrbio hormonal, tinha cisto no ovário. Eu tomei remédio pra desmanchar, pra dissolver. Aí, eu fiquei um período sem tomar para tomar outro [para trocar a medicação]. Aí, eu engravidei da minha filhinha. Eu usava camisinha [masculina], de vez em quando, mas me incomodava. Eu tenho alergia à camisinha, me coçava e eu não queria ... ele tirava pra fora e nesse tirar pra fora eu engravidei. Foi um sufoco! ... eu queria DIU. Agora vamos ver. Acho que vou dar conta das duas. Eu acho que não vai dar problema, 
pode dar, assim, ciúmes. No começo da gravidez, eu queria tirar, ai! Eu queria tirarrr! Aí, ele brigou comigo porque eu queria tirar ela. Agora tá tudo bem!

\section{P- Como é ser mãe, mais de uma vez, ainda adolescente?}

E- No meu ponto de vista, eu não tenho nada contra de ser mãe cedo. Muito cedo, 12/13 anos, acho que não tem capacidade. Quando eu era mais nova, pensava, era insegura, pensava, sou muito novinha. Eu quero curtir ainda. Depois de estar mais sério o relacionamento, na minha cabeça, eu queria ser mãe.

É muita responsabilidade, a pessoa tem que se dedicar muito. Abrir mão de tudo, porque se perde a liberdade. Eu não perdi tanto assim. ... Eu saí bastante, saía ... me divertia, não tinha hora pra voltar pra casa. Mas como eu sou muito chegada a casa , não prejudicou esse lado. Outras pessoas já prejudica ... Mas eu conheço muita gente que é mãe hoje, que deixa filho largado em casa e vai pra balada. Porque não deu pra fazer naquela época, agora tá descontando. Pra mim, não prendeu, mas uma consulta médica que a gente tem que ir, que não dá pra levar criança, tem que arranjar alguém pra cuidar ... Meu marido trabalha ... mas a gente dá um jeito ... eu deixo com minha mãe.

Eu gosto mesmo de criança. É que eu já gosto mesmo, eu gosto de cuidar! Tudo que ela [primeira filha] faz, eu fico besta, é lindo e maravilhoso! Eu gosto de ver ela fazendo aquilo, então, ... 17/18 anos tem menina que já é cabeça ... tem outras que, não, né? Agora, eu conheço muita menina novinha, que bem dizer, que a mãe é a avó. Que eu mesmo, eu sou mãe. Eu falo! Eu tenho minha casa, minha mesmo, minha vida., sou independente.

P- O que você espera do futuro sendo mãe tão jovem?

E- Não, eu não quero mais ter filhos por causa das condições financeiras também, que hoje em dia está mais difícil ... A violência tá aumentando, os jovens nas drogas ... Eu penso assim ... será que eu vou conseguir dar jeito [nas filhas] nesta fase de balada? Minha preocupação não é tanto de ter, de criar, mas isso! A minha mãe, assim, a minha criação sempre foi boa!

Eu queria ter estrutura melhor, para dar mais conforto ... uma casa maior, minha casa tem só dois cômodos, aumentar mais ter uma vida boa.

Eu quero casar ... a gente já tá vendo tudo, pra casar no civil mesmo.

Não pretendo ter mais filho, porque dá ... dá trabalho. Um é bom, dois é bom, mais ... é demais! 
Pepita, 19 anos de idade, duas filhas [uma de dois anos aos 17 anos e outra de um mês]. Vive em união consensual com o pai das crianças que tem 22 anos. Está desempregado no momento. Moram em casa alugada. Estudou até a $2^{\mathrm{a}}$ série do ensino médio, fez pré-natal nas duas gestações.

P- Como foi para você ser mãe pela primeira vez?

E- Foi bom! Não foi planejado, mas foi bom! Não foi uma coisa assim que ... assim, aconteceu ... não é assim como muita gente diz: aconteceu. Eu não quero. Eu vou tirar, não! Nós estávamos namorando, começando, aconteceu, nós mantivemos a gravidez. Assim, tivemos consciência do que a gente fez ... também, tirar uma criança que não tem nada ... não tem culpa de nada ... Aí, a gente decidiu criar junto. Aí nós fomos morar juntos. Ah!, pra mim, sempre foi bom, mas ao mesmo tempo você fica meio, como se diz, sem noção, com medo de pegar nele, de tocar, de quebrar. Eu dei de mamar, não tive dificuldade.

P- Como aconteceu o nascimento do outro filho?

E- O segundo, também, não foi planejado mas, desta vez, estou tranqüila ... mas estou aceitando bastante.

P- Como é ser mãe, mais de uma vez, ainda adolescente?

E- Ter filho mais cedo, eu acho que depende da pessoa. Eu não aconselharia uma pessoa a ter. A sua vida muda, você não pode fazer as mesmas coisas que fazia. Mas assim, se a pessoa quiser coisa séria, criar uma família ele tem que ter. Mas também ter e deixar aí, jogado, não! Se uma pessoa quiser curtir, que curta, mas não venha ter filho pra deixar jogado. ... Eu acho que não é desculpa de uma mãe. É, pode ter cedo, mas tem que ter consciência. Eu não posso falar o que é muito cedo, pois a minha irmã mesmo teve o primeiro filho dela aos 14 anos e, pra ela também foi bom.

P- O que você espera do futuro sendo mãe tão jovem?

E- O meu sonho é que esteja todo mundo bem, feliz. As crianças educadas, na escola, estudando direitinho. Meu marido trabalhando, que agora ele está desempregado. O relacionamento está bom! Que eu pretendo que minhas filhas, meu marido, todo mundo tenha bastante saúde. Eu pretendo voltar a estudar de novo, mas eu não sei como ... eu parei antes de engravidar da primeira.

Esmeralda, 19 anos de idade, dois filhos [de 2,2 meses e outro de um mês]. O segundo nasceu prematuro de, mais ou menos, oito meses. Fez pré-natal nas duas gestações. Estudou até o segundo ano do ensino médio. Não trabalha. Parou de trabalhar 
por motivo da primeira gravidez. Vive em união consensual. O pai das crianças tem 21 anos.

P- Como foi para você ser mãe pela primeira vez?

E- Foi bom! Eu não quis engravidar, aconteceu. Eu não morava junto com meu marido, eu só namorava. Assim, acho que foi um pouco difícil. É bom porque a gente pode cuidar melhor, pode dar mais atenção, porque a gente pode acompanhar o crescimento ... a gente é mais nova, tem mais tempo. É ruim porque a gente é muito nova e não dá pra trabalhar. Tem parar de trabalhar pra cuidar da criança. Tive que parar de estudar. Aí, que é ruim. Eu fiquei um pouquinho assustada ... no começo ... porque perde a liberdade totalmente, mas, de tudo. O pior de tudo é ... a liberdade é o pior ... não pode sair, não pode fazer quase nada ... o que eu ganhei com o nascimento ... eu ganhei nada ... muito nada.

P- Como aconteceu o nascimento do outro filho?

E- O segundo também não foi planejado, mas está sendo diferente, porque eu tenho mais experiência. Está sendo bom.

P- Como é ser mãe, mais de uma vez, ainda adolescente?

E- Ser mãe é como eu falei, é difícil ... difícil pra tudo! Eu acho que tem que pensar mais pra ter cedo. Perde tudo! Meus pais disseram: - engravidou, agora tem que ter responsabilidade. Eles disseram que não íam ficar com ela [a criança] para eu poder sair. Minha mãe falou que eu tinha que aprender. Aí, fui morar com meu namorado. No primeiro mês da minha primeira filha, tive ajuda da minha mãe ... porque eu não sabia cuidar nada! Depois eu fazia tudo, trocar, dar banho, de mamar. Eu acho que deve esperar até uns 28 anos ... Assim, esperar terminar seus estudos. Não acho bom ter filho muito cedo, nem muito tarde, também, porque pode não acompanhar o crescimento da criança.

P- O que você espera do futuro sendo mãe tão jovem?

E- Futuro? Ah!, voltar a estudar ... voltar a estudar! Ai! Eu quero voltar a estudar quando eles tiverem maior. Trabalhar! ... poder ter minha casa ... parar de pagar aluguel. Mas, meus filhos ... não tenho nenhum projeto ...

Ágata, 19 anos de idade, dois filhos [uma de três anos e um de 40 dias]. Estudou até a $2^{\mathrm{a}}$ série do ensino médio e interrompeu os estudos no início da primeira gravidez porque estava tendo muito enjôo. Fez pré-natal dos filhos. Vive em união consensual com rapaz de 33 anos, há cerca de três anos. Mora em casa própria, construída sobre a casa da cunhada. 
P- Como foi para você ser mãe pela primeira vez?

E- Eu gostei, eu me senti bem! A gravidez foi planejada, eu namorava meu marido e nós ficamos juntos, aí, aconteceu a gravidez.

Eu não sabia dar de mamar, dar banho, trocar ... Essas coisas, mas aprendi. Eu aprendi no hospital onde eu dei à luz pela primeira vez ... no Amparo Maternal. ... Lá é ótimo, eu gostei de lá ... não tenho nada do que reclamar ... é, lá é ótimo ... Eu gostei. No Hospital Ipiranga, também, [onde deu à luz ao segundo] foi maravilhoso ... lá todos atende muito bem a gente.

P- Como aconteceu o nascimento do outro filho?

E- Esse aqui não foi planejado. Eu parei de tomar remédio, tava descansando, tava usando camisinha [masculina], mas eu queria mesmo mais um, mais cedo ou mais tarde.

P- Como é ser mãe, mais de uma vez, ainda adolescente?

E- Acho melhor ser mais mãe mais cedo, que quando eu ficar mais velha, ele já tá criado. Às vezes, mais velha pode ter problema na gravidez. Eu vejo muitas, mais velhas, que têm problemas. Não que tem idade certa pra ter filho, qualquer idade pode ter filho, mas acho que quanto mais nova é melhor pra evitar problema na gravidez ... mais pelo problema da saúde mesmo. Pra mim, não teve nada difícil, tá bom ... até agora, tá bom.

P- O que você espera do futuro sendo mãe tão jovem?

E- Eu quero terminar de estudar ... tive que parar na segunda série, no início da primeira gravidez porque estava tendo enjôo. Depois arrumar um serviço, trabalhar ... pra cuidar deles melhor, porque é melhor, né? A gente tando trabalhando pra cuidar, né? Dar um bom estudo pra meus filhos quando eles tiver grande, quando eles crescer ter uma profissão ...

Planejado, assim, eu não quer ter mais filho, não! Mas, se acontecer ... Pra meu marido, também, tá bom só dois.

Marcassita, 17 anos de idade, dois filhos [um de 1,7 anos e outro de 25 dias]. Estudou até a quarta série do ensino fundamental. Tentou voltar a estudar no ano seguinte mas engravidou e teve que interromper. Vive em união consensual com o pai do segundo filho. Mora em casa alugada. Não trabalha. Fez pré-natal nas duas gestações. O pai do primeiro tinha 18 anos, quando nasceu o primeiro filho. O pai do segundo tem 44 anos. 


\section{P- Como foi para você ser mãe pela primeira vez?}

E- Ah! Maravilhoso! O primeiro, não foi programado, veio mesmo de surpresa. Eu namorava, aí fiquei junto, um mês. Aí, não deu certo, eu separei. Eu nem sabia que estava grávida quando eu separei. Eu procurei ele quando o bebê já tava com três meses ... ele falou que ía assumir ... aí, o bebê ficou internado com diarréia. Eu gostei de ser mãe ... eu dei à luz no Vila Alpina ... cuidei bem dele, dei de mamar, me ensinaram a cuidar dele ... minha mãe me ajudou muito, me deu a maior força ... se não fosse a minha mãe! ... eu morava com ela.

\section{P- Como aconteceu o nascimento do outro filho?}

E- Eu estou achando bom, gosto de cuidar ... agora, tudo bem ... esse eu já quis ... foi tudo bem ... eu também quis porque o pai, ele também assumiu, registrou. O primeiro é o G o segundo é o $C$.

P- Como é ser mãe, mais de uma vez, ainda adolescente?

E- Por um lado é bom, que quando você tiver uns 30 anos, eles já vão estar grandes ... Quando eu tiver uns 30, o primeiro vai estar com 20 e este vai ter mais ou menos 18 anos. Por outro lado, você perde a sua juventude Assim ... não dá mais pra sair, você fica mais com seus filhos, né? Mas em compensação, é só olhar pra carinha deles ... que já basta. Eu acho que ... no começo, eu me arrependi, se eu fosse escolher agora, eu teria com uns 18 ... se eu fosse planejar eu teria com 18/20 anos.

P- O que você espera do futuro sendo mãe tão jovem?

E- Ai, meus filhos ... que eles sejam homens de bem, que eu quero dar tudo pra eles ... eu quero tentar fazer o máximo que eu puder pra eles ... dá tudo pra eles, o que eu puder dar pra eles ... que não falte nada a eles.

Eu quer voltar a estudar ... eu queria fazer veterinária ... eu tentei voltar depois do primeiro filho, mas aí, engravidei e tive que parar de novo. Mas eu só vou estudar a até a terceira ... eu ... trabalhar, talvez um curso de secretária ... ter a nossa casa.

Jade, 18 anos de idade, dois filhos de 1,3 anos e outro de 20 dias. Vive em união consensual. Morava na casa dos pais do companheiro de 20 anos, mas, no momento este se encontra detido, então, retornou para casa da mãe. Interrompeu os estudos no segundo ano do ensino médio, mais ou menos no sexto mês da primeira gravidez. O namorado não estudava e ganhava a vida como entregador em domicílio. 
P- Como foi para você ser mãe pela primeira vez?

E- Eu gostei, foi uma experiência boa, não é que eu quis ... quis e não quis ... porque eu não me preveni. Eu me assustei na hora que eu soube que estava grávida ... mas eu desconfiava que estava grávida ... acho que sou boa mãe ... minha mãe me ensinou um pouco no começo ... mas eu sempre cuidei bem porque minha irmã teve filho e eu sempre ajudei ela cuidar.

P- Como aconteceu o nascimento do outro filho?

E- Este segundo estourou a bolsa em casa e eu cheguei no hospital quase nascendo ... foi um choque, porque no começo, eu não queria, não foi programado. O outro tinha seis meses. Mas agora, tudo bem, o segundo é mais fácil, porque você está mais acostumada ... um pouco mais tranqüila ...

P- Como é ser mãe, mais de uma vez, ainda adolescente?

E- É bom! Não que me arrependi, mas, se fosse um tempo atrás, eu não teria ... perdi baaastante a liberdade! Eu não era muito de sair mais agora com os filhos fica difícil, né? O bom é que eu tenho eles!

Assim, idade ideal pra ter filho, não tem. Tem que ter uma situação boa, sua casa ...

P- O que você espera do futuro sendo mãe tão jovem?

E- Bem, trabalhar. Eu trabalho, trabalho em confecção da minha irmã, trabalhei até os oito meses, agora não sei ... meu menino fica com a cunhada do meu namorado ... Agora, não sei como vai ser com o segundo ... Vou esperar um pouco ... esperar ele sair da prisão ... trabalhar os dois ... voltar estudar ... um dia ter uma casa ... é assim, a gente morava na casa do meu sogro ... tipo assim, tava construindo em cima da casa do meu sogro, mas aí ele foi preso e nós paramos de construir.

\section{DISCURSOS DOS PAIS}

Jacinto, 16 anos de idade, dois filhos [uma filha de 1,2 anos e um filho de 22 dias]. Estuda na primeira série do ensino médio. Trabalha em loja. Vive em união consensual com a mãe das duas crianças que tem 15 anos. Mora na casa da mãe e seu padrastro com sua companheira. 
P- Como foi para você ser pai pela primeira vez?

E- O primeiro, eu achei estranho, assim, depois me acostumei. Mas nós programamos ele, não teve problema nenhum. Mas, minha mãe também casou cedo, com 12 , com 13 teve minha irmã [com 17 anos, casada, mas sem filhos] e com 14, eu nasci. Primeiro, eu achei estranho, depois me acostumei, é bom ... não acho ruim, não ruim. Acho que sou bom pai, é ... eu ajudo a cuidar dele ... trocar , dar banho ...

P- Como aconteceu o nascimento do outro filho?

E- Foi bom, foi programado. Este não achei estranho, não. Tipo, pra seguir a minha mãe, ela teve dois. Vai ser legal os dois. Vai ser melhor pra mim, já tenho experiência com o outro, tô cuidando melhor ... agora também é um menino.

P- Como é ser pai, mais de uma vez, ainda adolescente?

E- Eu gostei. Pra mim, acho que é bom, dentro do que eu quero mesmo. Eu não gosto de rua, é minha característica mesmo, não sou muito de sair ... não acho que perdi minha liberdade, pra mim, não! Pra mim, é melhor ter filho porque eu não gosto de ficar sozinho.

Pra mim não tem nada a ver a idade se a pessoa se gosta se assume o filho, não tem diferença. Só assim, de bom, tipo a minha mãe, ela tem trinta e eu 16 ... a gente trabalha junto, eu ajudo ela ... ter filho cedo é bom por isso. Não vejo nada de ruim!

P- O que você espera do futuro sendo pai tão jovem?

E- Eu pretendo me formar, terminar o colegial, não penso numa profissão ... ah! ... eu queria mesmo, assim, é ser engenheiro . Arranjar um emprego bom ... ... criar meus filhos ... não pretendo ter mais filhos, agora, não! Talvez daqui uns cinco anos ... mais um só ... um trabalho bom ... criar meus filhos ... pretendo casar, mas só quando tiver 18 anos e mais tarde morar na nossa própria casa.

Crisólito, 18 anos de idade, dois filhos, de 1,6 anos e outro de 26 dias. Sua companheira tem um filho de um outro namorado. Trabalha como carroceiro. Estudou até a $4^{\mathrm{a}}$ série do ensino médio. Vive em união consensual. Mora na casa de sua mãe.

P- Como foi para você ser pai pela primeira vez?

E- Ah! Achei meio estranho ... primeiro filho ... a gente fica assim ... como vou cuidar, mas é normal! 


\section{P- Como aconteceu o nascimento do outro filho?}

E- Ah! Eu me assustei um pouco, ele não foi programado. Então, no começo fiquei meio assim, depois você vai acostumando, acostumando e, se tiver uma educação como o outro vai ser normal ... vai educar a mesma coisa, vai dar a mesma educação do outro. Vai ser um pouco mais difícil porque você não tem aquele dinheiro, pá, né? Mas aí, nós dá um jeito. Minha mãe ajuda nós. O segundo vai ser mais fácil, o primeiro a gente já tira de letra ... bom, segundo e último!

\section{P- Como é ser pai, mais de uma vez, ainda adolescente?}

E- Certo ter filho cedo não é, né? Mas se vir também tem cuidar igual normal, é seu filho é bom, porque quando você vai ficando mais velho o filho vai cuidando mais de você. Vai mostrar pra você como é que é ... porque se você tem filho velho, você vai morrer e não vai nem ver o filho crescer ... não saber nem como é que é ... eu cuido dele como cuida uma mulher normal, quando a G. tava no hospital, eu que fazia tudo cuido da casa e tudo. O filho não tira a liberdade ... não tira, se você tiver sentimento, faz a coisa certa, como eu, não sou de balada, não curto nada, sou sossegado, fico em casa, trabalho certinho, chego em casa, descanso ... igual que uma pessoa que gosta de balada, sair todo final de semana, aí sim ... o pessoal fala ah! é chato, ficar com filho ... pra mim, não é chato, não! Pra mim, é como se fosse normal, mesmo quando chora à noite , eu não ligo, não ... igual o primeiro ... ele chorava assim, à noite, eu pegava ele, já não acordava ela [a esposa]. Pra mim, não tem nada de ruim de ser pai jovem ... pra algumas pessoas tem , né? Pra mim, não! Nem pra ela ... não tem problema. Eu vou cuidar do segundo, como eu cuidei do primeiro. Casar cedo, morar, assim, morar junto tudo bem, mas, ter filho cedo , não ... porque, assim, se a pessoa estuda ... aí, atrapalha um pouco, aí ela quer ajudar você, trabalhar e já atrapalha tudo. Ter filho é lá pra uns 20 , que a pessoa tá mais experiente ... igual eu, com 17 anos, eu já acabei acabado os estudos, já morava sozinho ... aí, eu cuidava da casa normal ... ela trabalhava , eu também trabalhava ...

Tem gente que não sabe cuidar de uma casa, fritar um ovo, trocar uma fralda, aí, já atrapalha tudo ... pra mim, não. Eu sei cuidar de casa ... e, igual eu cuido de um, eu cuido do outro.

\section{P- O que você espera do futuro sendo pai tão jovem?}

E- Dar uma casa melhor, ah!, um emprego melhor, pra mim ... vou terminar os estudos pra ter uma coisa melhor, pra dar uma coisa melhor pra eles ... ter um futuro bom ... assim, cuidar deles ... de vez em quando eu penso assim, vai crescer, vai virar o quê? ... não fazer nada errado ... que eu quando era mais novo, eu mexia com coisa errada, aí depois que eu comecei a namorar com a G, é que eu comecei a tomar jeito ... mexia com 
droga ... eu nunca usei nada ... aí, eu saí, comecei me concentrar, pegar o primeiro emprego, normal, trabalhar em padaria. Ter filho me ajudou a ter mais responsabilidade ... quando você é sozinho, você não vai ligar ... eu faço e não tô nem aí, qualquer coisa tá bom ... não liga pra nada, mas quando tem família, você pensa tem que trabalhar direitinho, certo, pra dar um futuro melhor pra eles .

O filho é espelhado em você, se você faz o certo e ele vê que você tá fazendo o certo , ele vai fazer o certo também ... se ele vê que você fazer errado, ele vai fazer errado ... o pai não é trouxa [ele vai pensar assim] ... ah, eu penso assim ... dar o melhor pra eles, ensinar o que é certo e errado.

Ônix, 18 anos de idade, dois filhos [de 1,6 anos e mais ou menos três meses] O primeiro com uma garota de 19 anos e o segundo de uma garota de 17. Estudou até o primeiro ano do ensino médio. Relata que foi expulso da escola porque era muito briguento. Está desempregado atualmente. Está noivo e pretende casar muito em breve. Mora em um cômodo para morar próximo à casa da segunda namorada.

\section{P- Como foi para você ser pai pela primeira vez?}

E- O filho não foi planejado, aconteceu. Ser pai pela primeira vez foi, durante a gravidez, foi como se fosse um sonho, mas depois que a criança nasceu, ficou a responsabilidade ... foi legal, mas foi muita responsabilidade. Eu cai na real, depois que o neném nasceu. Só depois que ele nasceu, que me deu um estalo... na cabeça. A responsabilidade é em três coisas, financeira, educação, a criação. A gente ficou (com a mãe do primeiro filho) junto só durante a gravidez. Foi bom ... mas não deu pra ficar junto, não houve entendimento.

P- Como aconteceu o nascimento do outro filho?

E- O segundo, também, não foi planejado ... mas foi diferente. Acho que nesse vai ser diferente. Acho essencial o pai ficar junto com o filho, entendeu? ... só que com a mãe do meu primeiro filho não pude ficar, porque nós não lutamos pra isso. Agora, com esse segundo, eu vou lutar pra ficar junto com ela. Vou ser um pai melhor ... lutar pra isso ... vou lutar pra ficar mais junto com ele. O primeiro, eu vejo a cada 15 dias ... agora vai ser diferente, porque eu vou casar e eu não vou poder ficar junto com ele ... eu vou poder ver ele, mas não vou poder ficar junto com a criação dele, entendeu? Agora que vou casar [com a mãe do segundo] ela colocou um tipo de barreira, pra falar a verdade ela não está querendo nem deixar eu ver ele [o primeiro]. Mas, com o segundo vai ser isso, então, vai ser diferente. 
Agora vai ser melhor que o primeiro porque agora aprendi algumas coisas, coisas que com o passar do tempo fui aprendendo.

P- Como é ser pai, mais de uma vez, ainda adolescente?

E- Eu não aconselharia não, vixe? Eu acho melhor esperar um pouco mais, porque eu fui pai pela primeira vez com 15/16 anos e é uma responsabilidade muito grande para bem dizer um adolescente ainda. Então, eu aconselharia que não fosse pai cedo, não! Ser pai muda muita coisa na vida da gente ...a gente amadurece muito. Mudou muito coisa, no meu jeito de ser, coisa que, antigamente, eu tinha a cabeça muito dura. Porque eu sei que as coisas mudaram agora.

O fato de ser pai é bom ... é uma satisfação ... uma coisa de ruim em ser pai muito jovem é que você perde muito, muita oportunidade, escola, trabalho ... de bom, de bom ... [pensa alguns segundos] não consigo ver nada.

Bom pai ... eu não sou ... eu acho que tenho que melhorar muita coisa como pai, tenho que melhorar um pouco em tudo.

Eu perdi muita coisa, muita coisas que poderia ter feito e, hoje, eu já não posso mais, perdi toda a minha liberdade. Porque sendo pai, o tempo que poderia ser todo seu, agora você tem que dar pro seu filho ... perde a liberdade. Não, me lembro de ganhar nada.

P- O que você espera do futuro sendo pai tão jovem?

E- Eu pretendo a voltar a estudar, arranjar um emprego ... pensar no futuro dos meus filhos ... dar o melhor pra meus filhos. Causa que o meu futuro, é o futuro dos meus filhos. Esse está sendo o meu projeto, dar o melhor, ter uma família estruturada. Eu estou botando muita confiança neste meu novo relacionamento.

Topázio, 19 anos de idade, dois filhos. O primeiro com uma ex-namorada e o segundo com a namorada atual com alguns meses de diferença de idade [um aos 18/19 anos, o outro de 19/20 anos]. Trabalha com promotor de supermercado e como músico de pagode. Estudou até o $3^{\circ}$ ano do ensino médio. Em união consensual, mora com seus pais e a namorada, mas estão prestes a mudar para uma casa alugada.

\section{P- Como foi para você ser pai pela primeira vez?}

E- Acho que nas respostas que você já deve ter de tudo, aí, não tem? Na verdade, no momento que ouvi isso, que ela estava grávida, eu senti um pouco de raiva. Eu falei, ah! não pode ser, eu não tô trabalhando ... só que por outro lado sempre foi o meu sonho, ser pai! Quando nasceu [o primeiro] foi uma surpresa. Assim, aquele momento que você vê a 
criança, assim, lá no berçário ... é uma coisa inexplicável, né? O meu coração acelerou, as lágrimas caíram, é uma emoção, fora do comum.

\section{P- Como aconteceu o nascimento do outro filho?}

E- O segundo foi mais tranqüilo [a emoção foi mais tranqüila] porque eu já estava acostumado com a idéia, mas o primeiro foi uma emoção muito grande. Acho que emoção maior eu não tive ainda.

O primeiro já foi um alerta, mas eu nunca ia imaginar que fosse acontecer de novo, mesmo porque quando nasceu o segundo, eu ainda não trabalhava, o que eu fazia dava pra me manter. Eu estava conseguindo me manter. Eu falei, agora não dá mais, e tal, tenho que começar trabalhar legal.

P- Como é ser pai, mais de uma vez, ainda adolescente?

E- Na minha família, graças a Deus! Eu tive uma família de pessoas, pessoas não ... meu irmão, que é falecido, se envolveu com drogas. Mas eu tive, Deus me deu um segmento [familiar] muito bom.

Em relação a filho, tudo que eu imaginava de negativo, foi o inverso. Eu não aconselharia a ter filho cedo, porque você é, praticamente, uma criança. Hoje, eu vejo assim, o quanto eu passei até chegar este momento de me estruturar, ficar com uma cabeça boa ... isso é reflexo deles. Mas hoje em dia poderia aconselhar a ter desde que tenha uma situação financeira boa, que perceba que é com a pessoa de sua vida. Pra você, não passar pelo mesmo caminho que eu percorri ... tá com um filho aqui, outro filho ali.

Namorei com uma garota, terminei com ela. Depois voltamos por um tempo, mas não deu certo e, já estava namorando um tempo com outra quando a ex me contou que estava grávida de alguns meses. Ela tomava remédio, quando a gente namorava. Eu imaginava que ela continuava tomando, mas ela parou e não me falou nada. Poucos meses depois, a namorada atual também engravidou. Agora, ela toma injeção, eu mesmo aplico ... você acha que é seguro?

Tipo assim, ter a situação boa, lá pra uns $24 / 25$, já pode criar um filhinho. Seria melhor na sua profissão, você vai estar melhor estabilizado, a sua cabeça vai passar por transformações. Acho que seria um idade ideal, assim. Igual eu, eu venci e continuo vencendo cada dia que passa, mas porque eu quero isso!

Ah!, eu perdi, muito, né? Sem dúvida, eu perdi! Na verdade, eu consigo acompanhar tudo [fazendo o que gosta], porque eu continuo tocando [pagode]. Perdi, né? Apesar de conseguir acompanhar muita coisa, eu perdi ... você fica longe da situação, 
financeira, assim, longe do seu ideal ... tenho vontade, sempre tive vontade de ter um carro, uma moto. Eu terei, com certeza, com o trabalho que estou ... só que ainda não tenho, vou ter ainda, não tive como conseqüência dos filhos, né? Por isso que eu falo, assim, da idade, porque com uns 25 anos você pode se estruturar melhor, né? Pode dar uma vida melhor. Acredito que, na verdade, ter um filho já é um ganho, mas você pode tirar de tudo isso, é que você pode olhar pra criança com outros olhos. Você se preocupa com pequenas coisas: o que está fazendo, se vai cair, se vai machucar. Eu amadureci bastante. Eu vejo, às vezes, tento fazer um comparativo antes dos filhos e pós. Eu mudei muito, muito, muito mesmo! Eu queria só jogar bola, só sair à noite, só dançar, só tocar, só curtir, só zoar, só vícios que eu não tenho, né? ... mas queria sempre estar na noite, assim. Mas hoje, se eu tiver um tempo disponível, eu vou querer tar com meus filhos.

Uma coisa boa é que quando eles vão crescendo você pode tar acompanhando, pode tar jogando um futebol. Eu acho que com meu filho mesmo, eu sei que vou jogar um futebol com ele, vai poder acontecer, tranqüilo! Eu vou tar inteirão, ainda.

P- O que você espera do futuro sendo pai tão jovem?

E- Ah!, eu tenho bastante sonhos na vida. Eu sou um nato sonhador, mesmo. Mas, eu queria mesmo é ter uma casa própria, isto é um sonho que eu estou almejando. Eu vou conseguir ainda. Eu tou batalhando pra isto, trabalho muito pra isto. O outro lado, é o sonho musical. Eu não queria, tipo, fazer muito sucesso, seu um rei, nada disso! Só que a minha mensagem chegasse, pelo menos, a todos brasileiros. Eu toco há bastante tempo, todo final de semana. Ah!, sim, poder sei lá, dar uma vida melhor pro meus filhos, muitas coisas, que eu não tive, conseqüências também de filhos. Meus pais tiveram muitos filhos, cinco e, cedo [sua mãe teve o primeiro aos 17 anos]. Então, sempre foi controlado, assim que eu me recordo, nunca faltou nada. Sempre que eu pedi, mesmo assim, com esforço, mas vinha, né? O que você me aconselha, assim, da minha história?

Diamante, 19 anos, com ensino médio completo. Iniciou a união consensual com a primeira namorada após a descoberta da primeira gravidez. Morava em apartamento alugado, pago por seu pai. Teve dois filhos com esta [três anos e um ano]. Vive em união consensual, pela segunda vez com uma garota de 17 anos, que espera um filho seu. Trabalha com seu pai no comércio. Tem carro do ano de 2004. Mora em casa, cujo aluguel é pago por seu pai, que também paga a mensalidade da escola de seus filhos e plano de saúde para ele, sua namorada e os dois filhos e ajuda em outras coisas além de ter uma retirada mensal que não é bem determinada, depende de suas necessidades. Já morou com a companheira e os dois filhos na casa de seus pais. 


\section{P- Como foi para você ser pai pela primeira vez?}

E- A primeira gravidez foi programada, só que não assim, pensando como seria realmente ter a criança. Foi programada assim, vamos ter! Vamos fazer um filho! Vamos ter um filho! Foi mais ou menos assim... não... a gente vai programar... vai ter um filho e para isso a gente tem que ter casa, pra isso a gente vai ter que ter uma boa estrutura... assim... familiar para educar, né? Foi mais um momento assim... queria ter a criança... só que... não pensando seriamente na educação... assim... para estruturar esta criança, né? Pro futuro dela.

O primeiro nascimento foi bem uma experiência... assim... foi difícil... não tinha tanta responsabilidade, era um pouco difícil conciliar o trabalho, com a escola, com cuidar do filho... era um pouco difícil, né? O mais difícil foi isso daí ... no começo.

P- Como aconteceu o nascimento do outro filho?

E- O segundo filho a gente queria também, mas a gente tava quase praticamente separando... tava separando! ... a gente quis mais ter por causa que o primeiro [filho] estava muito sozinho... aí , queria para ele ter um irmão.

O segundo já ... quando nasceu, nem o primeiro era tão pequeno [as crianças têm uma diferença de mais ou menos dois anos]. Então, foi mais fácil, já estava uma estrutura melhor de formação ... assim ... uma formação, dividia melhor o trabalho, já não estava estudando mais. Já tinha mais tempo pra cuidar tanto do primeiro como do segundo.

Olha, o primeiro é aquilo lá ... uma novidade ... você fica com um monte de expectativa. Sei lá, fica tentando imaginar como é que é, fica bem bobo. O segundo foi mais natural, já tinha o primeiro, foi mais normal.

P- Como é ser pai mais de uma vez, ainda adolescente?

E- Olha, até o primeiro... até nascer o segundo, acho que vem a responsabilidade... até nascer o segundo... muda muita coisa. .. tem a responsabilidade, mas não leva tão a sério.. até nascer o segundo ia levando assim... tem a responsabilidade, tem que fazer isso, fazer isso e aquilo pro filho. Lógico, que tem o pai que ajuda, tem a mãe. ... Então, você não fica tão em cima. Pelo menos, eu não levei tão a sério, tinha quem ajudava. Então, você fica tranqüilo porque tem a ajuda dos outros. Mas depois que o segundo... que ele começou a crescer, aí vem a responsabilidade.

Eu acho que, pra mim, foi bom porque eu amadureci mais rápido. Veio uma responsabilidade pra mim. A gente quando é adolescente... a gente faz muita besteira, no sentido... é muita irresponsabilidade com isso. Eu acho... fiquei mais responsável... tenho... 
tudo que vou fazer. Tenho mais consciência por causa dos meus filhos. Acho que a coisa boa pra mim, é que tenho eles... assim... e isso ajudou também para mim... para... como vou falar... ficar mais maduro.. amadureci mais rápido do que o normal.

Os filhos moram comigo. O Ju vai comigo pra loja na parte da manhã ... Aí um pouquinho antes do almoço, ele vai para casa pra tomar banho, almoçar pra ir pra escola. À tarde, eles vão pra escola [no final da tarde, a bisavó pega os dois filhos na escola e leva pra casa da avó]. Na hora de sair... quando as crianças deixam a escola, vão para casa da avó [que também trabalha na loja e lá, normalmente, comem alguma coisa até o pai chegar para pegá-los] na hora que saio da loja, pego os dois e levo pra casa. Fico com eles até eles dormirem. Praticamente, só não fico com eles à tarde.

Tenho a ajuda do meu pai e da minha mãe [mãe tem cartão de crédito em conjunto com ele]... meu pai paga o plano de saúde, aluguel, escola. Eu trabalho com ele.. ele me ajuda, não tenho um salário fixo ...

P- O que você espera do futuro, sendo um pai tão jovem?

E- Olha, eu penso assim que ... agora eu acho que eu estou ajudando eles pra crescer ... como eu sou novo, eu acho que é mais fácil o diálogo em todos os sentidos, estudo, logo mais o trabalho quando eles crescerem, também, o relacionamento que vão ter com namorada e tudo... eu acho que eu tô novo. Muita coisa vai ser boa, porque é bem aberta a nossa conversa, o diálogo é bem aberto, como um amigo, nem tanto como pai... é como pai, mas, por outro lado, como amigo. Eu tenho bastante orgulho de ser pai jovem. Eu espero que eles peguem firme com o estudo, se formem, não sei ... cada um vai escolher a profissão que vai querer. Eu espero mesmo que todos concluam os estudos, e ... ah! ... que fiquem bem! Cada um tenham a sua vida bem firmada, bem estruturada, que sigam um caminho certo, sejam pessoas honestas, que trabalhem, não desviem, não desandem para o lado errado ... drogas, roubo... essas coisas, assim ...

Pra mim, agora, é educar eles, trabalhar e ter uma vida certa. No momento não pretendo ter mais filhos ... cuidar deles ... e continuar tocando a vida, construindo cada vez mais a vida. Pretendo continuar meu trabalho na loja [do pai].

Observação: os comentários entre colchetes são grifos do pesquisador. 
ANEXO V 


\section{ANEXOVI}

